\title{
Genetic diversity and identification of putative recombination events in Grapevine rupestris stem pitting-associated virus
}

by

Ilani Mostert

Thesis presented in partial fulfilment of the requirements for the degree of Master of Science in the Faculty of Science at Stellenbosch University

Supervisor: Dr. H.J. Maree

Co-supervisor: Prof. J.T. Burger

December 2017 


\section{Declaration}

By submitting this thesis electronically, I declare that the entirety of the work contained therein is my own, original work, that I am the sole author thereof (save to the extent explicitly otherwise stated), that reproduction and publication thereof by Stellenbosch University will not infringe any third party rights and that I have not previously in its entirety or in part submitted it for obtaining any qualification.

Ilani Mostert

December 2017 


\begin{abstract}
Phylogenetic analysis for variant classification plays a key role in the characterisation of the aetiological role of viruses. The genomic regions selected to identify viral variants and the occurrence of recombination has the potential to influence tree topologies. To investigate the impact of these factors on variant classification, and to evaluate the success of certification schemes in eliminating virus infection, a diversity study was performed on Grapevine rupestris stem pitting-associated virus (GRSPaV), a ubiquitous virus commonly detected in cultivated vines and reportedly associated with Rupestris Stem Pitting disorder. Three surveys were conducted to characterise and compare the genetic diversity of GRSPaV on a global and local level, using a phylogenetic approach. The first constituted a collection of accessions from various countries to represent global virus diversity. A second survey was carried out on local mother blocks that previously conformed to certification requirements for South Africa. Finally, GRSPaV diversity in South African vineyards established prior to the implementation of current sanitary protocols was investigated. Two genomic areas, the coat protein and replicase domains, were selected for this study as these were used to characterise the sequence diversity of GRSPaV in previous studies. Mixed infections were found to occur within single vines, the genetic diversity of GRSPaV was confirmed with the clustering of sequences into five of the six distinct, currently recognised lineages, and a seventh, previously unclassified lineage was detected. Furthermore, the ability of the two domains to detect and classify variants was compared. Additional evidence for recombination in GRSPaV was provided and a correlation between recombinant sequences and inconsistencies between topologies generated by the two genome regions, was observed. Results indicate that disease control methods were moderately successful, but less effective at eliminating non-symptomatic variants. The study illustrates the effect of recombination on phylogenetic trees, and emphasises the importance of accounting for such factors in the characterisation of virus diversity. Increased knowledge of the recombination events within the GRSPaV genome could promote the development of a standardised method for variant classification and the clarification of the aetiological role of the virus.
\end{abstract}




\section{Opsomming}

Filogenetiese analise vir variantklassifikasie is belangrik vir die karakterisering van die etiologiese rol van virusse. Die genomiese areas wat gebruik word om virale variante te identifiseer tesame met die verskynsel van rekombinasie het die potensiaal om boomtopologieë te beïnvloed. Om die impak van hierdie faktore op variantklassifikasie te ondersoek, en om die sukses van sertifiseringskemas in die eliminasie van virusinfeksie te evalueer, is "n diversiteitstudie uitgevoer op "Grapevine rupestris stem pitting-associated virus" (GRSPaV), "n algemene virus wat gereeld in gekweekte wingerde opgespoor word en verbind is met Rupestris-stamverpitting. Drie opnames is uitgevoer om die genetiese diversiteit van GRSPaV op 'n globale en plaaslike vlak te karakteriseer en te vergelyk deur ' $\mathrm{n}$ filogenetiese benadering. Die eerste bestaan uit ' $\mathrm{n}$ versameling inskrywings uit verskeie lande om globale virusdiversiteit te verteenwoordig. ' $n$ Tweede opname is uitgevoer op plaaslike moederblokke wat voorheen aan Suid-Afrikaanse sertifiseringsvereistes voldoen het. Laastens is GRSPaV diversiteit in Suid-Afrikaanse wingerde wat voor die implementering van huidige sanitêre protokolle gevestig is, ondersoek. Twee genomiese areas, die kapsiedproteïen- en die replikasedomein, is geselekteer vir hierdie studie aangesien beide voorheen gebruik is om die nukleotiedvolgordediversiteit van GRSPaV in vorige studies te karakteriseer. Infeksies van meer as een variant is in enkele wingerdstokke gevind. Die genetiese diversiteit van GRSPaV is bevestig met die groepering van nukleotiedvolgordes in vyf van die ses afsonderlike variantgroepe wat tans in literatuur erken word, en 'n sewende, voorheen ongeklassifiseerde groep is opgespoor. Verder is die vermoë van die twee domeine om variante op te spoor en te klassifiseer, vergelyk. Addisionele bewyse vir rekombinasie in GRSPaV is gelewer, en ' $n$ korrelasie tussen rekombinante isolate en onreëlmatighede tussen topologieë wat deur die twee genoomareas gegenereer is, is waargeneem. Resultate dui daarop dat metodes om infeksies te beheer matig suksesvol was, maar minder doeltreffend om niesimptomatiese variante uit te skakel. Die studie illustreer die effek van rekombinasie op filogenetiese bome, en beklemtoon die belangrikheid daarvan om sulke faktore in ag te neem tydens die karakterisering van virusdiversiteit. Uitgebreide kennis van die rekombinasiegebeure in die GRSPaV genoom kan die ontwikkeling van 'n gestandaardiseerde metode vir variantklassifikasie bevorder, en help om die etiologiese rol van die virus op te klaar. 


\section{Acknowledgements}

I would like to express my sincere gratitude to the following individuals and institutions for their contributions to this study:

- Dr. H.J. Maree, for his exceptional mentorship, supervision, intellectual input, support and encouragement throughout this study.

- Prof. J.T. Burger, for his guidance and support, and for allowing me to form part of the Vitis research team.

- Dr. R. Bester, for her mentorship, skills training, support, guidance and unparalleled friendship, and for brightening every day.

- Winetech, for project funding.

- The National Research Foundation (NRF), for personal funding. Opinions expressed and conclusions arrived at, are those of the author and not necessarily to be attributed to the NRF.

- Vitis laboratory, for funding to attend The 50th Anniversary Congress of the Southern African Society for Plant Pathology, Drakensberg, South Africa.

- Stellenbosch University

- Members of the Vitis laboratory, for providing an enjoyable working environment.

- My friends, with special thanks to Mr. J. A. Lategan and "Sir" N. Zietsman.

- My family, especially my parents, for providing nothing but unconditional love and support. 


\section{Table of contents}

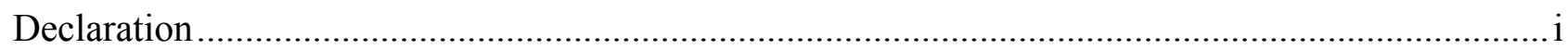

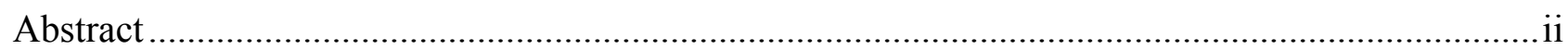

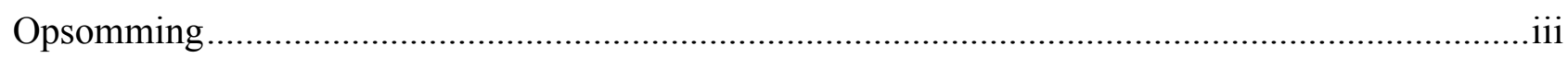

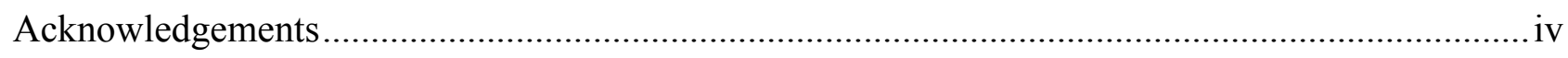

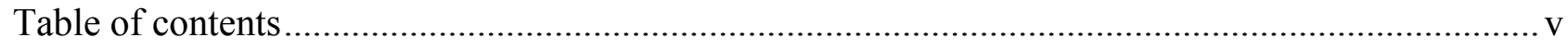

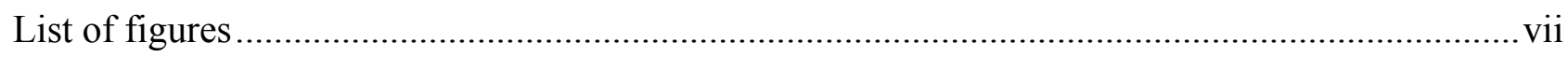

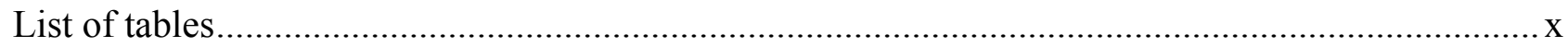

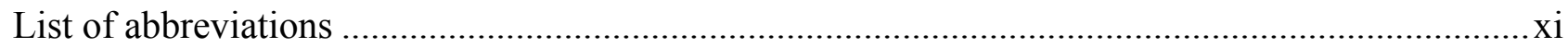

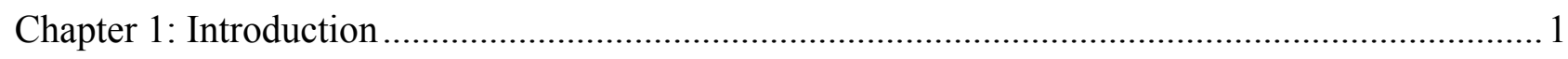



1.2 Problem statement.............................................................................................. 2

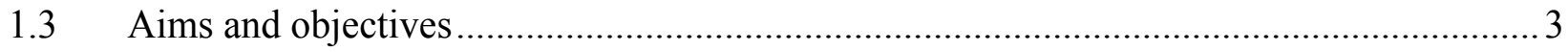



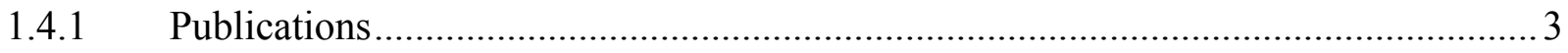

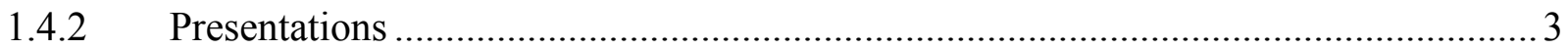

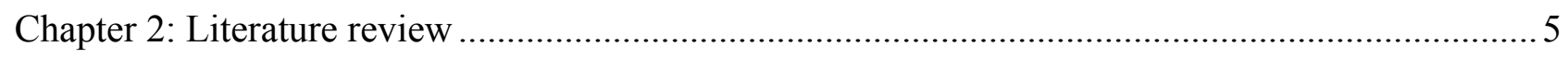

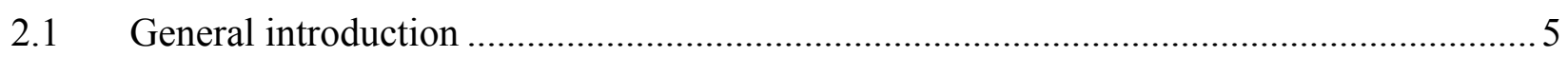





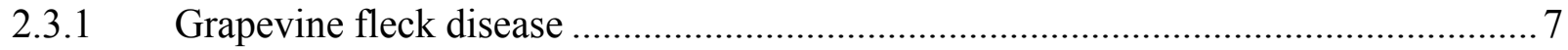

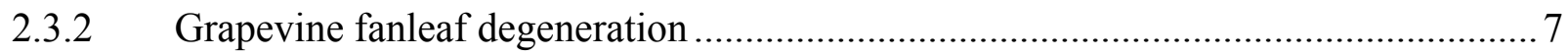





2.4 Grapevine rupestris stem pitting-associated virus ................................................... 12

2.4.1 Background, Morphology and Taxonomy …..................................................... 12

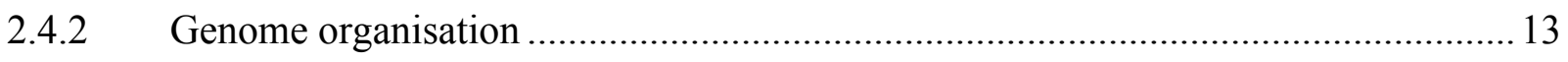

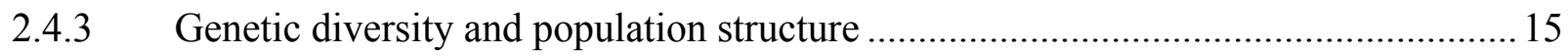

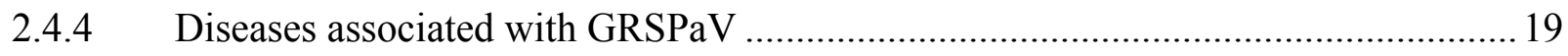

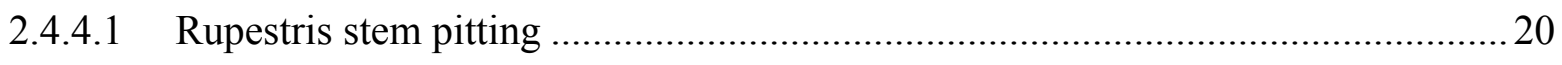

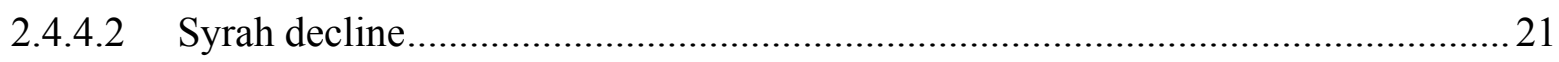

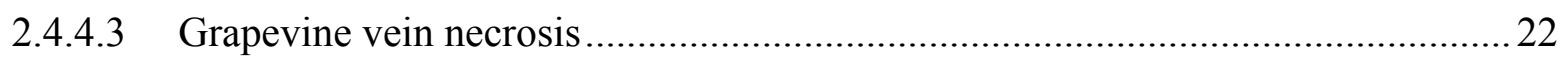

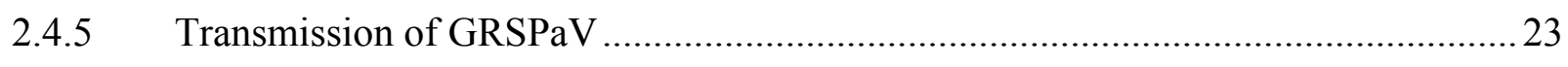

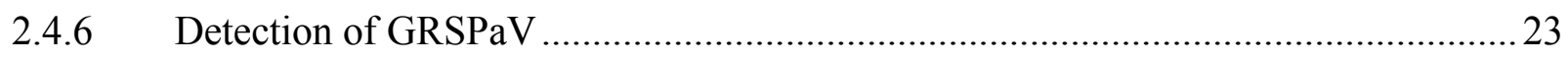




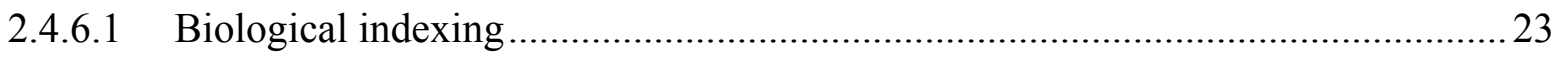

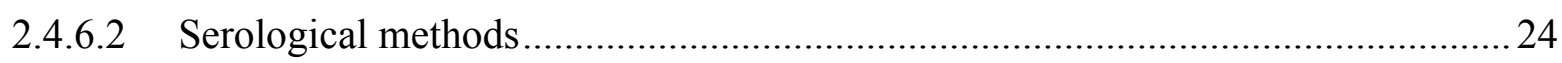

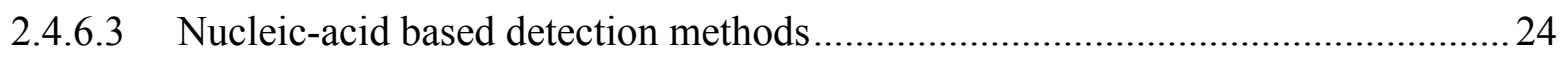



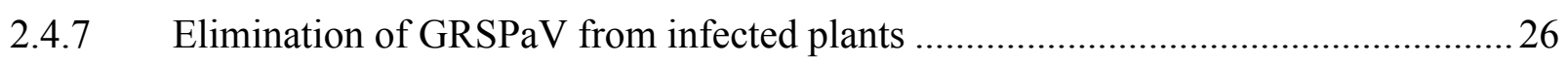



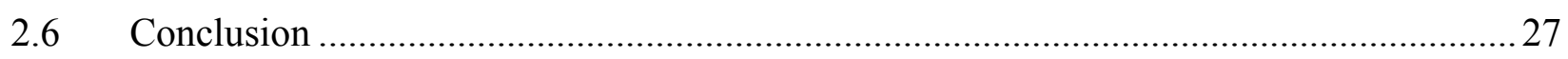

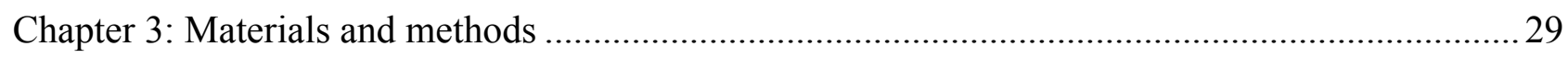

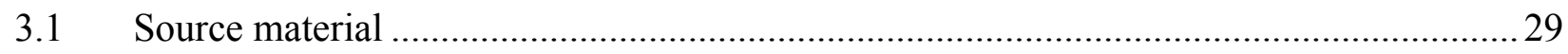

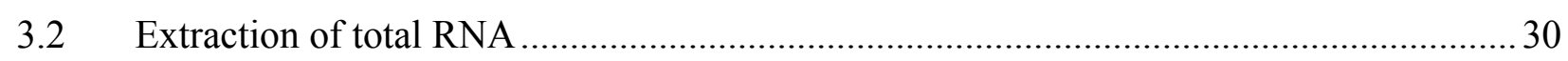

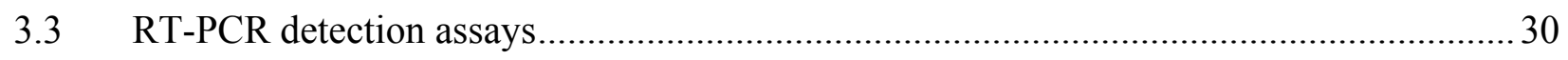

3.4 Amplification, cloning and sequencing of two genomic regions of GRSPaV isolates ..... 30

3.5 Classification of whole genome reference sequences.................................................. 32



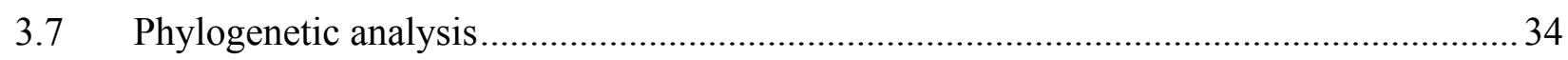

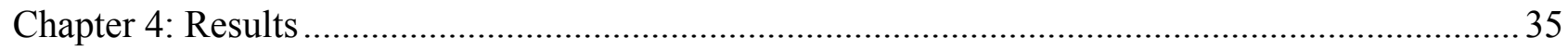

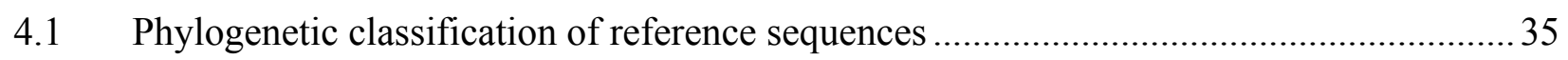

4.2 Prevalence of GRSPaV in three respective surveys .................................................... 35

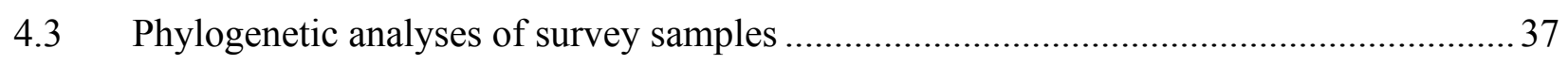

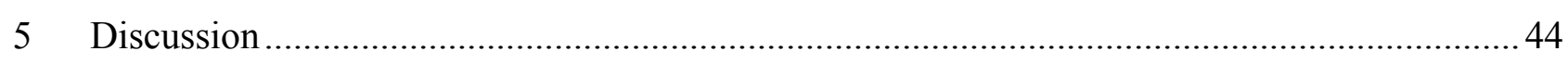






\section{List of figures}

Figure 1 Clearing of veinlets and deformed leaves are typical symptoms of GFkD (Constable and Rodoni, 2011).

Figure 2 (A) Leaf malformations caused by Infections malformation, one of the syndromes of GFLD. Marginal and petiolar sinuses are wide open, leaves are puckered, and marginal teeth prominent. (Martelli et al., 2001), Descriptions of Plant Viruses 385 (Adams and Antoniw, 2006); (B) Malformed shoots growing in a zigzag pattern as a result of GFLD infectious malformation (Maliogka et al., 2015); (C) Chrome yellow discoloration caused by GFLD yellow mosaic syndrome (Maliogka et al., 2015); (D) Yellow banding spreading from the veins to interveinal areas as a result of co-infection of GFLV and Grapevine yellow speckle viroid. Image courtesy of the Canadian Food Inspection Agency.

Figure 3 Symptoms of GLD on a red (left, Vitis vinifera cv. Cabernet Franc) and a white (right, Vitis vinifera cv. Chardonnay) cultivar (Maree et al., 2013). 9

Figure 4 (A) A Kober 5BB indicator showing symptoms of Kober stem grooving (top) compared to a healthy indicator (bottom) (Hooker, 2017); (B) An LN 33 vine showing Corky bark symptoms. Due to a rapid increase in phloem tissue, internodes are swollen with a cracked surface. Image courtesy of D. Goszczynski; (Minafra et al., 2017); (C) Stem grooving on a LN 33 indicator as a result of LN 33 stem grooving (Hooker, 2017); (D) Pitting and grooves on the stem of $V$. rupestris St. George, the indicator for Rupestris stem pitting. Image courtesy of the Vitis lab, Department of Genetics, Stellenbosch University.

Figure 5 Filamentous virion morphology as visualised by negative stained (left) and antibodydecorated (right) electron micrography. Bar represents $100 \mathrm{~nm}$ (Petrovic et al., 2003).....

Figure 6 Representation of the complete GRSPaV genome. MTR, methyltransferase; HVR, highly variable region, AlkB, alkylation B; OTU, ovarian tumour-like cysteine protease; P-Pro, papainlike cysteine protease; HEL, helicase; POL, RNA-dependent RNA polymerase; TGB, triple gene block; CP, capsid protein (Meng and Rowhani, 2017). 
Figure 7 Phylogenetic tree of GRSPaV sequence variants based on a partial sequence of the RdRP region of the replicase polyprotein amplified by broad spectrum primers RSP35 and RSP36. Sequences derived from whole genomes are indicated with hash signs (\#). Sequences for which a partial genome was available, are indicated with an asterisk (*). A sequence of the corresponding region from ASPV (Apple stem pitting virus, D21829) was used as an outgroup. Phylogenetic analyses were performed using the Neighbour Joining algorithm. Nodes with bootstrap values of less than 50\% were collapsed (Meng and Rowhani, 2017). Corresponding lineages according to $\mathrm{Hu}$ et al. (2015) are indicated on the left. 17

Figure 8 Phylogenetic tree of GRSPaV sequence variants based on nucleotide sequences of the coat protein gene. Sequences derived from whole genomes are indicated with hash signs (\#). A sequence of the corresponding region from ASPV (Apple stem pitting virus, D21829) was used as an outgroup. Phylogenetic analyses were performed using the Neighbour Joining algorithm. Nodes with bootstrap values of less than 50\% were collapsed (Meng and Rowhani, 2017). Corresponding lineages according to $\mathrm{Hu}$ et al. (2015) are indicated on the left. .18

Figure 9 Premature reddening of leaves as a result of Syrah decline (left) compared to an unaffected vine (right) (Battany et al., 2004).

Figure 10 Grapevine vein necrosis in Richter 110R. Image courtesy of D. Boscia, (Meng and Rowhani, 2017)..... 22

Figure 11 Phylogenetic trees constructed from $18 \mathrm{GRSPaV}$ genome reference sequences available on GenBank. Topology (A) is based on whole genome sequences, whereas alignments used to construct the other trees were trimmed to contain only the CPreg (B) and pREP (C) genome areas. Phylogenies were constructed in MEGA V7.0.18 (Kumar et al., 2016), using the Neighbour-Joining method with default parameters and 1000 bootstrap replicates, as described in Glasa et al. (2017). Nodes were collapsed using a bootstrap cut-off value of 50 and bootstrap values are displayed above nodes. Lineages of reference sequences are stated on the right of each figure. Recombinant sequences are indicated in red. 36 
Figure 12 Summary and schematic representation of refined recombination detection results of whole genome reference sequences obtained from RDP4 V8.20 (Martin et al., 2015). Event numbers are given in brackets next to each recombinant sequence. Breakpoint positions are indicated by the black arrows on the schematic representation of each recombinant genome. Parental lineages were inferred from the most likely parental sequence as indicated by the program, and the areas contributed by them are colored accordingly. Grey blocks indicate the positions of the $p R E P$ and CPreg genomic areas under investigation in this study.

Figure 13 Tabular and schematic summary of recombination events detected within the CPreg and pREP areas of survey samples or reference sequences using RDP4 V8.20 (Martin et al., 2015). Event numbers are given in brackets next to each schematic representation of a recombinant genome areas, and breakpoint positions are indicated with arrows. Parental lineages were inferred from subsequent lineage classification of parental sequences, and areas contributed by parental sequences are colored accordingly.

Figure 14 Phylogenetic analysis of GRSPaV diversity based on $p R E P(\mathbf{A})$ and CPreg (B) alignments with recombinant sequences removed. Trees were constructed by the Maximum Likelihood method using RAxML-HPC Black Box V8.2.10 on CiPRES and visualised and cartooned using Figtree V1.4.3 (Rambaut and Drummond, 2015). Bootstrap values are indicated at branch nodes. Nodes with bootstrap support values of less than 50 were collapsed. The height of each clade is an indication of the number of sequences therein, whereas clade depth indicates diversity. Reference sequences of respective lineages within each group are indicated next to clusters, and lineage names are given at the right of each topology followed by the number of clones within the $(\mathrm{NV}, \mathrm{OV}$ and $\mathrm{MB})$ surveys that clustered within specific groups.

Figure 15 Comparison of lineage classification of clones based on the CPreg and $p R E P$ areas within each survey. Recombinant sequences were excluded as they did not belong to a single specific lineage. No group IIc could be discerned within tree topologies based on CPreg sequences... 42 


\section{List of tables}

Table 1 Symptoms of the four syndromes of Rugose wood disease on biological indicators $V$. rupestris (St. George), LN 33 and Kober 5BB.

Table 2 Summary of the complete genome sequences of GRSPaV available on GenBank. Lineages are classified according to all nomenclature systems, based on phylogenetic analyses by $\mathrm{Hu}$ et al. (2015) and Meng and Rowhani (2017). 16

Table 3 Summary of the primers used in this study. The name, sequence, annealing temperature $\left(\mathrm{T}_{\mathrm{A}}\right)$, extension time (Ext) and expected amplicon size is given.

Table 4 Summary of pairwise nucleotide and amino acid identity comparisons of whole and trimmed reference sequences, within and between variant groups. Average percentage identities are indicated in brackets next to each range. Pairwise comparisons within group IV were not calculated, as only one sequence is available for this group. Reference sequences for group IIc were classified as group III in the CPreg comparisons. All analyses were conducted in CLC Main Workbench V7.7.1 (CLC Bio-Qiagen, Aarhus, Denmark). 38

Table 5 Summary of pairwise nucleotide and amino acid identity comparisons of trimmed reference and survey sequences, within and between variant groups. Sequences were classified according to phylogenetic analyses performed in this study (Figures 14A and 14B). Recombinant sequences and unclassified sequences were excluded from these analyses. Average percentage identities are indicated in brackets next to each range. Group IV was omitted from intra-group pairwise comparisons, as only one sequence is available for this group. All analyses were conducted in CLC Main Workbench V7.7.1 (CLC Bio-Qiagen, Aarhus, Denmark). 


\section{List of abbreviations}

AIC

AlkB

ASPV

BIC

BLAST

cDNA

CP

CTAB

cv.

dsRNA

ELISA

GFkD

GFkV

GFLD

GFLV

GLD

GLRaV

GLRaV-1

GLRaV-2

GLRaV-3

GLRaV-4

GLRaV-7

GRSPaV

GVA

GVB

GVD

GVE

GVF

GVN

HEL

HMW

HVR

MB
Alkaike Information Criteria

alkylation B

Apple stem pitting virus

Bayesian Information Criteria

Basic Local Alignment Search Tool

complementary DNA

capsid protein or coat protein

cetyltrimethylammonium bromide

cultivar

double-stranded RNA

enzyme-linked immunosorbent assay

Grapevine fleck disease

Grapevine fleck virus

Grapevine fanleaf degeneration

Grapevine fanleaf virus

Grapevine leafroll disease

Grapevine leafroll associated virus

Grapevine leafroll associated virus 1

Grapevine leafroll associated virus 2

Grapevine leafroll associated virus 3

Grapevine leafroll associated virus 4

Grapevine leafroll associated virus 7

Grapevine rupestris stem pitting-associated virus

Grapevine virus A

Grapevine virus B

Grapevine virus D

Grapevine virus E

Grapevine virus F

Grapevine vein necrosis

RNA helicase

high molecular weight

highly variable region

Mother block survey 


\begin{tabular}{|c|c|}
\hline mRNA & messenger RNA \\
\hline MTR & methyltransferase \\
\hline NCR & non-coding region \\
\hline NGS & next-generation sequencing \\
\hline NNI & Nearest Neighbour Interchange \\
\hline $\mathrm{nt}$ & nucleotide \\
\hline NV & Global survey (Nietvoorbij) \\
\hline ORF & open reading frame \\
\hline OTU & ovarian tumour-like cysteine protease \\
\hline OV & Old Vine survey \\
\hline P-Pro & papain-like cysteine protease \\
\hline PCR & polymerase chain reaction \\
\hline POL & domain encoding an RNA-dependent RNA polymerase \\
\hline $\mathrm{RdRP}$ & RNA-dependent RNA polymerase \\
\hline RSP & Rupestris stem pitting \\
\hline RT-PCR & Reverse transcription polymerase chain reaction \\
\hline RT-qPCR & Quantitative reverse transcription polymerase chain reaction \\
\hline RWD & Rugose wood disease \\
\hline RW & Rugose wood \\
\hline SAWIS & South African Wine Industry Information and Systems \\
\hline SD & Syrah decline \\
\hline SPR & Subtree Pruning and Regrafting \\
\hline $\mathrm{T}_{\mathrm{A}}$ & annealing temperature \\
\hline TAE & Tris-acetate-EDTA \\
\hline TGB & triple gene block \\
\hline TGB1 & triple gene block 1 \\
\hline TGB2 & triple gene block 2 \\
\hline TGB3 & triple gene block 3 \\
\hline VRC & viral replication complex \\
\hline
\end{tabular}




\section{Chapter 1: Introduction}

\subsection{Background}

Grapevine species of the genus Vitis are one of the most widely cultivated perennial fruit crops in the world (Reisch and Pratt, 1996). The majority of grapes harvested are used for wine, of which approximately 24.7 billion litres are produced annually (SAWIS, 2016). According to the latest statistics, South Africa is the seventh largest wine-producing country in the world, accounting for $3.6 \%$ of the annual global wine production (SAWIS, 2016). In 2015, the industry contributed more than R36 billion to the national gross domestic product and is responsible for the employment of over 289000 people (Conningarth Economists, 2015).

Grapevine is the woody crop for which the largest number of intracellular pathogens have been reported (Martelli, 2014). More than 70 viruses have been identified, the majority of which are associated with disease complexes that hold the potential to cause a severe reduction in economic returns from crops (Barba et al., 2015; Basso et al., 2014; Martelli, 2017, 2014; Nascimento et al., 2015). Rugose wood disease is one of four major disease complexes responsible for economic losses. The disease is geographically widely distributed, and comprises four individual syndromes, each caused by different combinations of viruses and characterised by definitive symptoms induced on each of three biological indicators. The syndromes are: Corky bark, LN 33 stem grooving, Kober stem grooving and Rupestris stem pitting (RSP) (Martelli, 2017).

Grapevine rupestris stem pitting-associated virus (GRSPaV) is a member of the genus Foveavirus, family Betaflexiviridae (Adams et al., 2004; Martelli et al., 2007) and arguably the most ubiquitous virus of grapevines (Minafra and Boscia, 2003). Its biological association with RSP has been documented extensively (Maliogka et al., 2015). Symptoms include basipetal pitting on the stem and swelling above graft unions. Furthermore, infection with GRSPaV has also been shown to have a strong correlation with Grapevine vein necrosis (GVN) (Borgo et al., 2009). The association of GRSPaV with Syrah decline (SD) has been proposed, but a consensus on the role of the virus in this disease has not been reached (Al Rwahnih et al., 2009). Vitis species are the only known hosts of $\mathrm{GRSPaV}$ and no vector has been established for this virus, with the only known means of transmission being through vegetative propagation or grafting (Maliogka et al., 2015). 
Currently, six distinct molecular variant groups (I, IIa, IIb, IIc, III and IV) of GRSPaV are recognised (Hu et al., 2015). Each variant group is represented by the complete genome of one or more isolates. The symptoms caused by GRSPaV vary greatly between viral variants and the infected cultivar. Infection of the indicator 'St. George' grapevines ( $V$. rupestris Scheele) with variants belonging to group IIa does not elicit symptoms associated with RSP, but is strongly associated with GVN. Variants of group IIc, on the other hand, cause RSP. Furthermore, group IIb-infection causes mild or no symptoms, whereas group I is closely associated with SD (Borgo et al., 2009; Habili et al., 2006; Lima et al., 2006a; Meng et al., 2005; Al Rwahnih et al., 2009). Inconsistencies in symptom expression may be explained by simultaneous infection by multiple viruses, or multiple sequence variants of GRSPaV. Optimisation of GRSPaV detection and development of an accurate system for the identification of GRSPaV variants is required to characterise the aetiological role of this virus.

\subsection{Problem statement}

The sustainability of the viticulture industry is threatened by a number of diseases associated with virus infection, several of which are associated with GRSPaV. Sequences of the coat protein open reading frame and a segment of the replicase polyprotein domain are used for the detection and classification of GRSPaV variants, six of which have been identified. However, variable symptom expression between viral variants and host cultivars created difficulties in describing the exact aetiological role of GRSPaV in these diseases. Recombination has been detected both in and between the coat protein and replicase regions of GRSPaV (Alabi et al., 2010; Glasa et al., 2017) and can lead to inconsistencies in variant classification (Alabi et al., 2010).

Increased knowledge of recombination events within GRSPaV and the effect of recombination on the generation of tree topologies is required for the optimisation of variant detection and classification. This will lead to an increased understanding of the role of GRSPaV in its associated diseases, and assist in the ultimate improvement of tools to manage and limit its impact. 


\subsection{Aims and objectives}

This study aimed to characterise the genetic diversity of Grapevine rupestris stem pitting-associated virus, to assess the usefulness of two genomic regions to discern between viral variants, and to investigate the effect of recombination on variant classification. To achieve this, the following objectives were formulated:

- To evaluate the current classification of all available GRSPaV whole genome sequences and identify isolates to serve as references for variant groups.

- To obtain high quality RNA from accessions representative of vines from various countries, from vines in mother blocks that previously conformed to the certification requirements in South Africa, and from South African vineyards that were established before current sanitary protocols were imposed.

- To identify accessions or plants containing GRSPaV using diagnostic primers designed to detect a wide spectrum of variants.

- To isolate, clone and sequence coat protein and partial replicase fragments from each positive accession or plant.

- To perform recombination and phylogenetic analysis to identify and classify sequence variants using whole genome references.

\section{$1.4 \quad$ Research outputs}

Publications and presentations contributed towards by this study are listed below

\subsubsection{Publications}

- Mostert, I., Burger, J.T., and Maree, H.J. 2017. Characterization of the genetic diversity and identification of putative recombination events in Grapevine rupestris stem pitting-associated virus. Submitted to Archives of Virology.

1.4.2 Presentations (Person responsible for presenting is underlined)

- Mostert I, Burger JT, Maree HJ. Characterization of the genetic diversity and identification of putative recombination events in grapevine rupestris stem pitting-associated virus detected 
in virus diseased vines. The 50th Anniversary Congress of the Southern African Society for Plant Pathology, 16-19 January 2017 (Drakensberg, South Africa) Poster and flash presentation. 


\section{Chapter 2: Literature review}

\subsection{General introduction}

Grapevine, classified into the genus Vitis, family Vitaceae, is one of the oldest domesticated fruit crops in the world (Reisch and Pratt, 1996). Vitis vinifera holds the most significant socio-economic interest as cultivars belonging to this species are widely propagated for the production of wine, table and raisin grapes. Other species from the genus Vitis, including $V$. riparia, $V$. berlandieri and $V$. rupestris, are used as rootstocks due to their increased resistance to pathogens such as phylloxera (Daktulosphaira vitifoliae) and mildews, and their superior ability to adapt to abiotic stress and soil conditions (Terral et al., 2010; This et al., 2006).

In 2016, the estimation of the total global surface area under vines was more than 7.5 million hectares from which approximately 24.7 billion litres of wine were produced. In the same year, South Africa ranked seventh among the top wine producing countries worldwide, producing more than 1 billion litres of wine of which 428.4 million litres were exported (SAWIS, 2016). In 2013, the industry accounted for $1.2 \%$ of the national gross domestic product and provided job opportunities to 289151 South African residents (Conningarth Economists, 2015). This illustrates the importance of wine production within South Africa and stresses the need for the strict control of factors that can limit the sustainability of the viticulture industry.

As a result of the prolonged history of cultivation and transmission of pathogens through vegetative propagation, the sanitary status of Vitis has severely deteriorated (Basso et al., 2014; Martelli and Boudon-Padieu, 2006). Currently, grapevine is the woody crop that plays host to the largest number of intracellular infectious pathogens, including xylem- and phloem-limited prokaryotes, viroids and viruses. The perennial nature of grapevine, combined with the practice of grafting and the national and international exchange of infected material, contributes to an increase in infections by multiple pathogens within a single plant. This causes disease complexes of which the aetiology is often difficult to describe (Al Rwahnih et al., 2009; Basso et al., 2017).

More than 75 viruses, viroids and phytoplasmas have been identified for grapevine (Martelli, 2014). Diseases associated with infection by these agents often result in a reduction in the productive lifespan of affected vineyards (Barba et al., 2015; Basso et al., 2014; Martelli, 2014; Nascimento et al., 2015). Disease symptoms vary depending on geographical location, climate, agronomic conditions, host cultivars, and viral species or variants. Furthermore, a combination of several viruses in a single plant 
can cause an increase in the severity of symptoms, or emergence of new symptoms (Basso et al., 2017; Bonfiglioli et al., 1998). Viruses are locally transmitted over short distances via insect, mite or nematode vectors. The long-distance dispersal of pathogens through the exchange of inadequately sanitised propagation material further favours the formation of complex diseases, and has become a major cause of concern (Al Rwahnih et al., 2009; Basso et al., 2014; Martelli and Boudon-Padieu, 2006).

\subsection{Certification and control}

The potential of grapevine-infecting viruses to cause a severe reduction in economic returns from crops has led to the global implementation of strict certification programs. Mother blocks are established as a source of propagating material and can play a major role in the global dispersal of viruses if managed incorrectly. It is therefore of utmost importance to ensure the absence of pathogens in this material, limiting the inoculum potential in areas where local and long-distance transmission of viruses via insect or nematode vectors is a risk (Maliogka et al., 2015; Martelli, 2014; Roossinck et al., 2015). Nurseries or mother vine plots must be established in areas where the presence of harmful organisms is limited by chemical or biological control, and the soil of these vineyards must be free of any material or organism with the potential to transfer pathogens to newly planted stocks. It is also crucial to establish source blocks far from vines showing symptoms of virus diseases (Martelli, 2014).

\subsection{Major diseases caused by grapevine viruses}

Currently, around 30 diseases of grapevine are associated with viruses or virus-like infections and are characterised by a broad variety of symptoms (Martelli, 2014). Lower yields decrease the economic returns from affected crops. Furthermore, fruit quality is reduced by a change in berry characteristics such as pigment and sugar content. As a result, the acidity levels of wine produced are altered, decreasing the commercial value of crops (Barba et al., 2015; Basso et al., 2014; Martelli, 2014; Nascimento et al., 2015). The four main, most widespread virus-associated disease complexes responsible for economic loss are Grapevine fleck disease, Grapevine fanleaf degeneration disease, Grapevine leafroll disease and Rugose wood disease (Minafra et al., 2017). 


\subsubsection{Grapevine fleck disease}

Grapevine fleck disease (GFkD) is the result of infection by Grapevine fleck virus (GFkV), from the family Tymoviridae (Sabanadzovic et al., 2001). Symptoms are often latent in $V$. vinifera, however, on the indicator $V$. rupestris St. George, vein clearing of $3^{\text {rd }}$ or $4^{\text {th }}$ order veins is observed, causing localised translucent spots on leaves (Figure 1). Foliage deformation in the form of wrinkling, twisting and upward curling, and stunted growth are also symptoms of GFkD (Fajardo et al., 2012; Martelli, 2014). There is no known insect vector for GFkV, and it is not mechanically transmissible (Basso et al., 2017; Sabanadzovic et al., 2000).

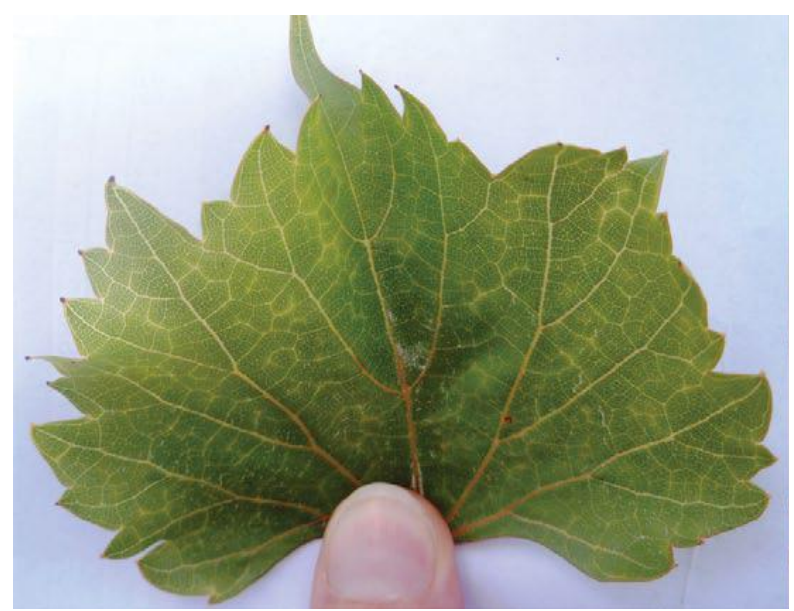

Figure 1 Clearing of veinlets and deformed leaves are typical symptoms of GFkD (Constable and Rodoni, 2011).

\subsubsection{Grapevine fanleaf degeneration}

Grapevine fanleaf degeneration (GFLD) is one of the oldest and most devastating known grapevine diseases (Martelli and Savino, 1990). The main infectious agent is Grapevine fanleaf virus (GFLV), a nepovirus from the family Secoviridae, although other nepoviruses have also been associated with this disease (Martelli et al., 1993). Two respective syndromes of GFLD are recognised and caused by different strains of GFLV. Infectious malformations are characterised by a bright yellow foliar discoloration in infected plants. Leaves are asymmetrical and puckered, with toothed margins, closer primary veins and widely open petiolar sinuses (Figure 2A). Shoots are malformed, branch abnormally and form double nodes. Internodes are short and grow in a zigzag pattern (Figure 2B). Irregular ripening of berries is also observed. In contrast, varying degrees of chrome yellow discolorations on all vegetative parts are indicative of yellow mosaic syndrome (Figure 2C). Little malformations are observed of the leaves and shoots. Both infectious malformations and yellow mosaic syndrome causes a decrease in bunch size and quantity (Digiaro et al., 2017). Co-infection of GFLV with Grapevine yellow speckle viroid causes vein banding, characterised by yellow banding 
along the veins of the leaf, with chrome-yellow flecks spreading outward from the veins to interveinal areas (Figure 2D) (Andret-Link et al., 2004; Martelli and Boudon-Padieu, 2006; Raski et al., 1983). Soil-borne nematodes from the genus Xiphinema are known vectors of GFLV (Cohn et al., 1970; Demangeat et al., 2010; Villate et al., 2008).

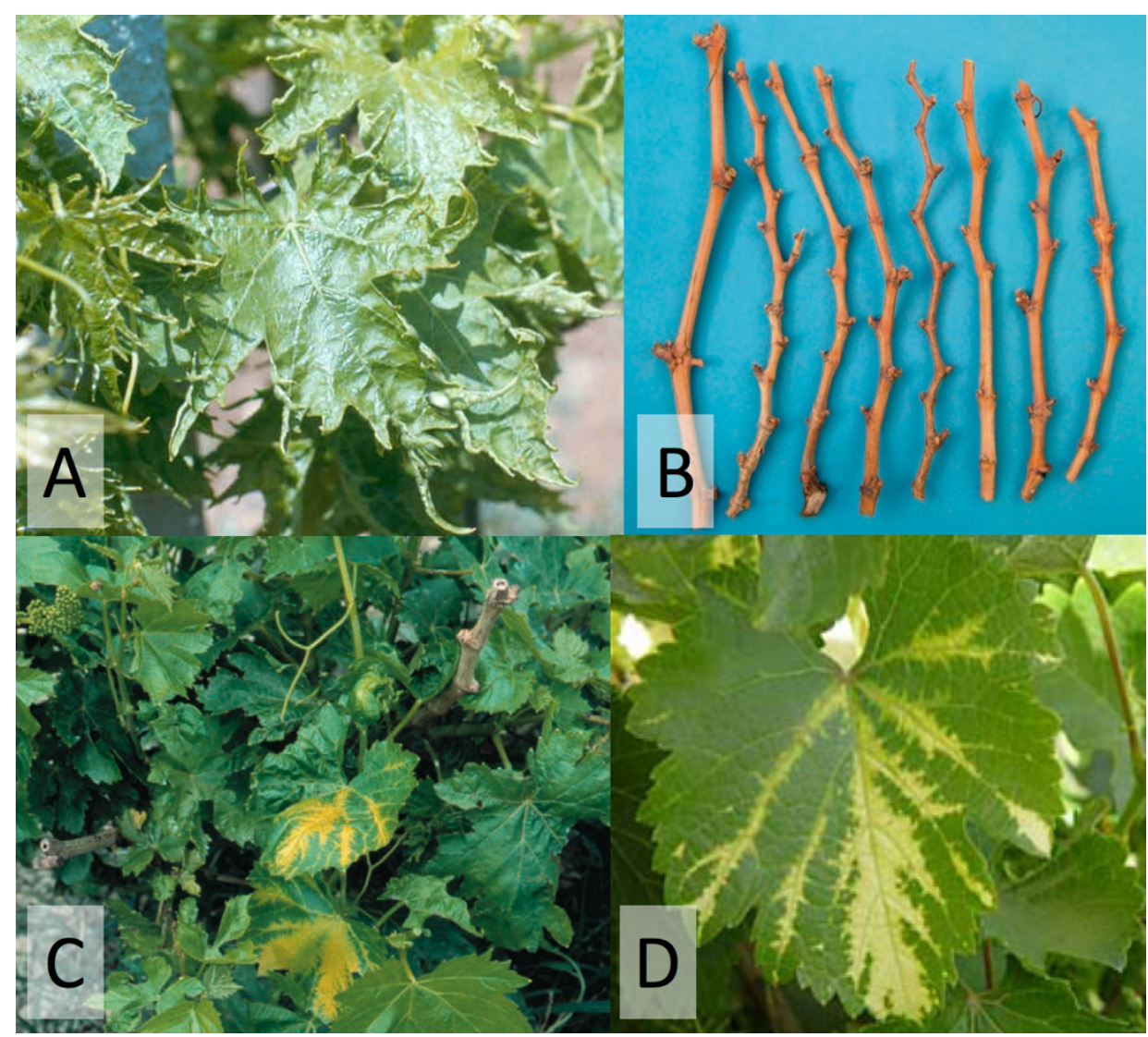

Figure 2 (A) Leaf malformations caused by Infections malformation, one of the syndromes of GFLD. Marginal and petiolar sinuses are wide open, leaves are puckered, and marginal teeth prominent. (Martelli et al., 2001), Descriptions of Plant Viruses 385 (Adams and Antoniw, 2006); (B) Malformed shoots growing in a zigzag pattern as a result of GFLD infectious malformation (Maliogka et al., 2015); (C) Chrome yellow discoloration caused by GFLD yellow mosaic syndrome (Maliogka et al., 2015); (D) Yellow banding spreading from the veins to interveinal areas as a result of coinfection of GFLV and Grapevine yellow speckle viroid. Image courtesy of the Canadian Food Inspection Agency.

\subsubsection{Grapevine leafroll disease}

Grapevine leafroll disease (GLD) is a widespread, economically damaging grapevine disease caused by viruses. Its associated agents are Grapevine leafroll associated viruses (GLRaVs) belonging to the family Closteroviridae. Of all the GLRaVs, GLRaV-2 and -3 are the most widely spread (Alabi et al., 2016; Almeida et al., 2013; Atallah et al., 2012; Maree et al., 2013; Martelli et al., 2012; Naidu et al., 2015, 2014). Symptoms vary depending on the viral strain or complex of viruses causing the infection, and are mild in V. labrusca, but severe in $V$. vinifera (Basso et al., 2014). The disease is 
characterised by a downward rolling of the leaf margins of infected plants. Leaves of red cultivars are reddened with green veins, whereas the leaves of white cultivars show a yellow discoloration (Figure 3). Other symptoms include graft-incompatibility and delayed maturation (Naidu et al., 2015, 2014). GLRaV-1, -3 and -4 are transmitted via soft scale insects and mealybugs, whereas no insect vectors have been reported for GLRaV-2 and -7 (LeMaguet et al., 2012; Martelli and Boudon-Padieu, 2006; Tsai et al., 2012, 2010).

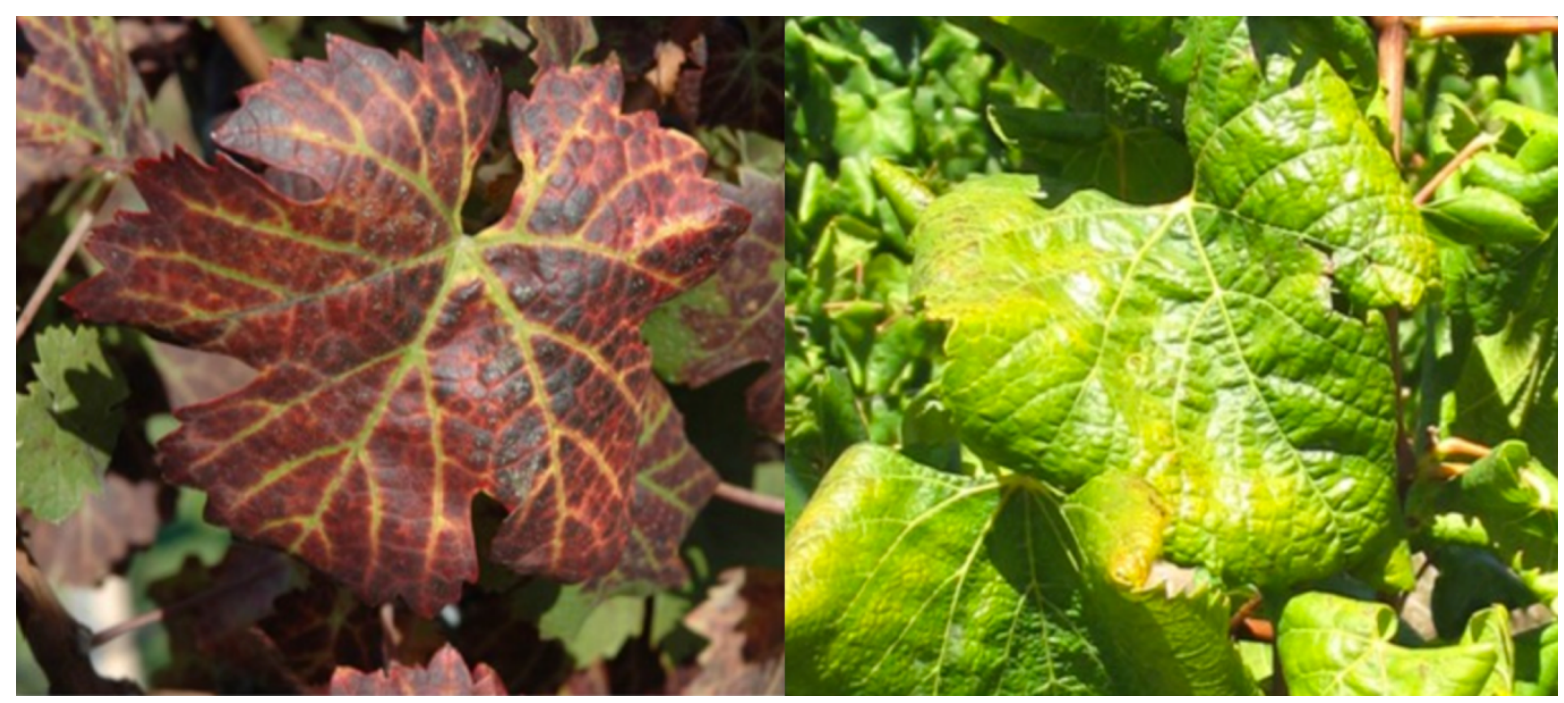

Figure 3 Symptoms of GLD on a red (left, Vitis vinifera cv. Cabernet Franc) and a white (right, Vitis vinifera cv. Chardonnay) cultivar (Maree et al., 2013).

\subsubsection{Rugose wood disease}

First documented in 1954 (Hewitt, 1954) but not thoroughly identified and recorded before its discovery in Italy seven years later (Graniti and Ciccarone, 1961), Rugose wood disease (RWD) was thought to be regional until reported in Hungary in 1967 (Martelli et al., 1967). At present, it is accepted that the disease is geographically widely distributed, having been detected in most major grape growing regions of the world (Martelli and Boudon-Padieu, 2006). Symptoms are rarely observed in ungrafted grapevines, but emerge in some grafted vines. The majority of American Vitis scion and rootstock combinations are not affected (Martelli et al., 1993). The symptoms of RWD greatly vary between assorted scion/rootstock combinations, ranging from complete graft incompatibility in some to being entirely latent in others. Furthermore, expression of symptoms is climate-dependent, decreasing in severity under cool or wet conditions. Considering global climate change and varying climates in different grape-growing regions, this can impact the standardisation of visual detection tools and characterisation of symptoms associated with the disease. Affected crops show a decrease in vigour and longevity, occasionally failing to survive the first few years after 
planting. The disease is characterised by pits or grooves akin to peg- and ridge-like protrusions on the cambium, and swelling of the bark above the graft union. Swollen bark appears thick and corky with a spongy texture and a rough appearance, causing differences in the relative diameter of the scion and rootstock. Even though no definitive symptoms are observed on the foliage, some cultivars exhibit leafroll-like symptoms such as rolled, yellowed or pink-tinted leaves. Delayed bud opening in spring, smaller and fewer bunches and a crop reduction of up to $30 \%$ can lead to an overall decrease in yield (Martelli, 2014).

The complex consists of four individual syndromes: Kober stem grooving, Corky bark, LN 33 stem grooving and Rupestris stem pitting. Each syndrome is caused by assorted combinations of viruses and characterised by definitive symptoms induced on biological indicators $V$. rupestris (St. George), LN 33 (Couderc 1613 X Thompson seedless) and Kober 5BB (Vitis berlandieri Planch X Vitis riparia Michx) (Savino et al., 1989). Although the four respective syndromes are not commonly distinguishable from one another in the field, they are recognised by differential symptoms induced after graft transmission to aforementioned indicator plants (Table 1) (Maliogka et al., 2015; Martelli, 2014; Martelli et al., 1993).

Even though the aetiology of RWD has been extensively studied, difficulties in fulfilling Koch's postulates have prevented the establishment of the exact relationship between single viruses (or combinations of viruses) and symptoms associated with disease complexes (Meng and Gonsalves, 2007). Extrapolation of the connection between viral complexes, host cultivars and disease symptoms is further complicated by the common occurrence of mixed infections (Prosser et al., 2007). Nonetheless, putative agents have been identified and, in some cases, connected to individual diseases that constitute the Rugose wood (RW) complex. These viruses are members of the genera Vitivirus and Foveavirus, which belong to the family Betaflexiviridae. Members of this family typically consist of flexuous, filamentous virions, which are phloem-restricted in grapevines and transmitted through vegetative propagation and grafting. The vitiviruses, Grapevine virus $A, B, E$ and $F$ (GVA, GVB, GVE and GVF) are transmissible via several mealybugs and soft scale insects, whereas there is no known vector for the foveavirus, Grapevine rupestris stem pitting-associated virus (GRSPaV) (Martelli et al., 2007; Martelli and Jelkmann, 1998). No specific vector has been identified for Grapevine virus D (GVD). The role of ampeloviruses in the production of a help factor to assist in vitivirus transmission has not been confirmed (Minafra et al., 2017). GVA is the putative associated agent of Kober stem grooving, while GVB and GVD are reportedly involved in the aetiology of Corky bark syndrome, although results of studies investigating this involvement were not consistent. 
Rupestris stem pitting is biologically associated with GRSPaV, whereas the aetiological roles of GVE and GVF in RWD remain to be confirmed (Maliogka et al., 2015).

Table 1 Symptoms of the four syndromes of Rugose wood disease on biological indicators $V$. rupestris (St. George), LN 33 and Kober 5BB.

\begin{tabular}{|c|c|c|c|}
\hline & V. rupestris (St. George) & LN 33 & Kober 5BB \\
\hline Kober stem grooving & No symptoms. & No symptoms. & $\begin{array}{l}\text { Marked grooves on the } \\
\text { stem (Figure 4A). }\end{array}$ \\
\hline Corky Bark & $\begin{array}{l}\text { Grooving and pitting on } \\
\text { entire stem. }\end{array}$ & $\begin{array}{l}\text { Grooving and pitting on } \\
\text { the entire stem; stunted } \\
\text { growth; rolled, reddened } \\
\text { leaves; rapid increase in } \\
\text { phloem tissue causing } \\
\text { swollen internodes with a } \\
\text { cracked surface } \\
\text { (Figure 4B). }\end{array}$ & No symptoms. \\
\hline LN 33 stem grooving & No symptoms. & $\begin{array}{l}\text { Grooves on the stem } \\
\text { (Figure } 4 \mathrm{C} \text { ); no } \\
\text { discoloration or } \\
\text { malformation of the } \\
\text { foliage; no swelling of the } \\
\text { shoot. }\end{array}$ & No symptoms. \\
\hline Rupestris stem pitting & $\begin{array}{l}\text { Swollen graft nodes; } \\
\text { distinct band of basipetal } \\
\text { pitting on the stem } \\
\text { extending downward from } \\
\text { the point of inoculation } \\
\text { (Figure 4D). Symptoms } \\
\text { appear } 2 \text { - } 3 \text { years after } \\
\text { grafting. }\end{array}$ & No symptoms & No symptoms. \\
\hline
\end{tabular}




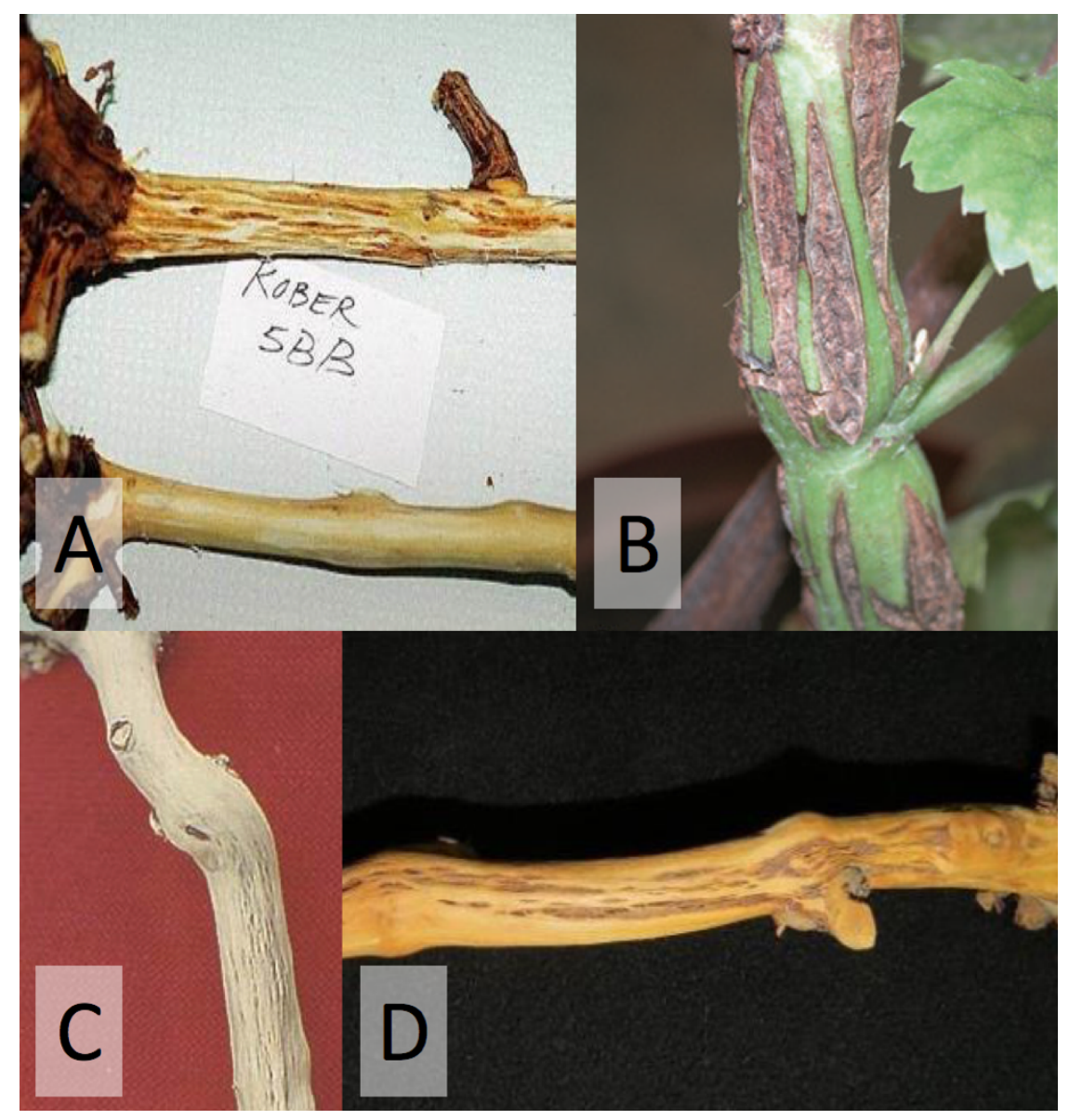

Figure 4 (A) A Kober 5BB indicator showing symptoms of Kober stem grooving (top) compared to a healthy indicator (bottom) (Hooker, 2017); (B) An LN 33 vine showing Corky bark symptoms. Due to a rapid increase in phloem tissue, internodes are swollen with a cracked surface. Image courtesy of D. Goszczynski; (Minafra et al., 2017); (C) Stem grooving on a LN 33 indicator as a result of LN 33 stem grooving (Hooker, 2017); (D) Pitting and grooves on the stem of $V$. rupestris St. George, the indicator for Rupestris stem pitting. Image courtesy of the Vitis lab, Department of Genetics, Stellenbosch University.

\subsection{Grapevine rupestris stem pitting-associated virus}

\subsubsection{Background, Morphology and Taxonomy}

Grapevine rupestris stem pitting-associated virus (GRSPaV) is arguably the most ubiquitous virus of grapevines and is commonly detected in cultivated vines (Alabi et al., 2010; Meng et al., 2006; Nolasco et al., 2006; Terlizzi et al., 2010). It is a definitive member of the family Betaflexiviridae (order Tymovirales) and the genus Foveavirus (Adams et al., 2005, 2004; Martelli and Jelkmann, 1998). The non-enveloped virion comprises a monopartite, single stranded positive sense RNA genome contained by a flexuous, filamentous capsid. It has a helical-symmetrical morphology, is 723 $\mathrm{nm}$ in length and 10-12 $\mathrm{nm}$ in diameter, and can been observed via electron microscopy with the use of antiserum and antibody coating (Figure 5) (Petrovic et al., 2003). 


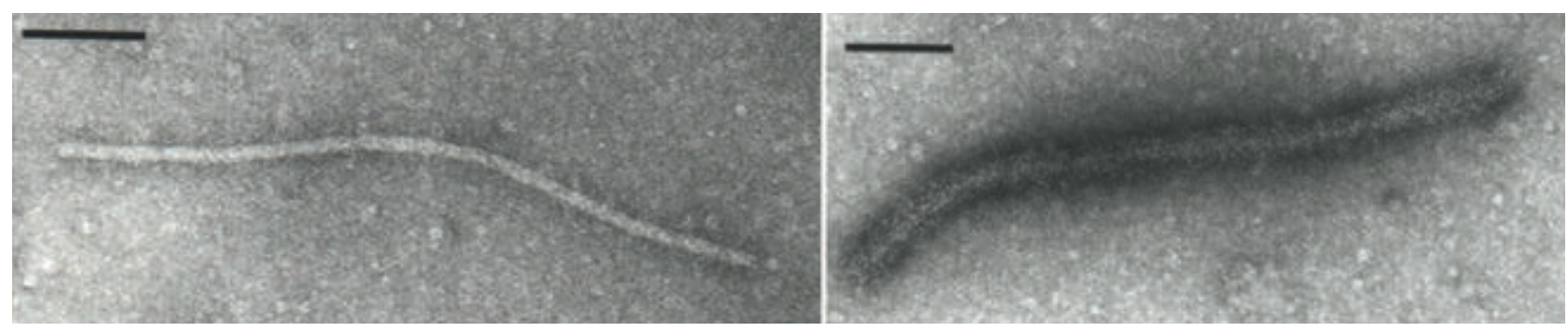

Figure 5 Filamentous virion morphology as visualised by negative stained (left) and antibody-decorated (right) electron micrography. Bar represents $100 \mathrm{~nm}$ (Petrovic et al., 2003).

\subsubsection{Genome organisation}

The 8725 nucleotide (nt) genome includes five open reading frames (ORFs), and a sixth has been proposed. The ORFs are flanked by two non-coding regions (NCRs): a $60 \mathrm{nt} 5$ ' NCR which is presumably capped, and a $175 \mathrm{nt}$ polyadenylated 3' NCR (Figure 6). Each NCR contains invariable sites essential for virus replication (Meng and Rowhani, 2017). The genome structure is identical for all isolates for which the full genome sequences are available (Giampetruzzi et al., 2012; Hu et al., 2015; Lima et al., 2009, 2006a, 2006b; Meng et al., 2005, 1998; Morelli et al., 2011; Poojari et al., 2013; Zhang et al., 1998). Using autofluorescent protein tagging and fluorescence microscopy, the subcellular localisation of protein products of all five ORFs have been described (Meng and Li, 2010; Prosser et al., 2015; Rebelo et al., 2008). The majority of the genome (nt position 61-6546; GenBank accession AF057136) consists of ORF 1, encoding a $244 \mathrm{kDa}$ polyprotein containing elements involved in virus genome replication and mRNA transcription. These elements are conserved among the Alphavirus superfamily of RNA viruses (Koonin and Dolja, 1993; Strauss and Strauss, 1994). A methyltransferase, encoded for by MTR, is responsible for encapsulating the 5 ' end of genomic and subgenomic RNAs (Caruthers and McKay, 2002; Kadaré and Haenni, 1997; Rozanov et al., 1992; Soultanas and Wigley, 2001). The MTR is followed by a $300 \mathrm{nt}$ untranslated highly variable region (HVR). Identities as low as 55\% on an amino acid and 53\% on a nucleotide level between sequence variants indicate that this region probably does not play an essential role in the virus infection cycle (Habili et al., 2006; Lima et al., 2009, 2006a; Meng and Rowhani, 2017). The RNA helicase encoded for by HEL is responsible for unwinding the replicative form dsRNAs (Kadaré et al., 1995), and the POL-domain encodes an RNA-dependant RNA polymerase (RdRP) (Koonin, 1991) catalysing the replication of RNA from the template.

The papain-like cysteine protease (P-Pro), the ovarian tumour-like cysteine protease (OTU) and the alkylation B (AlkB) domains are present in the majority of Betaflexiviridae. OTU and AlkB are almost exclusively observed in RNA viruses that infect woody perennials, leading to the assumption 
that the two domains play an active role in the process with which these viruses infect woody plants (Bratlie and Drabløs, 2005; Makarova et al., 2000; Meng and Rowhani, 2017). Presumably, one or both of the cysteine protease domains are also involved in the cleavage of the replicase polyprotein, assisting in the formation of functional replication machinery (Makarova et al., 2000; Meng et al., 1998; Zhang et al., 1998). It has not yet been established whether the replicase polyprotein of GRSPaV undergoes autocatalytic cleavage and what type of processing is involved, however, results based on various experimental systems indicate that the product of ORF 1 undergoes cleavage at three sites: on the 3' side of the MTR, and on both sides of the HEL domain (Udaskin, 2016). The replicase polyprotein forms globular structures or bodies resembling the viral replication complexes (VRCs) observed in plants infected by other positive-strand RNA viruses. These VRC-like structures are localised in near proximity to the endoplasmic reticulum of infected cells. Membranes of the endoplasmic reticulum are continuous with the outer membrane of the nucleus, and are covered in ribosomes involved in protein synthesis (Buck, 1996; Nagy and Pogany, 2008; Prosser et al., 2015; Waigmann et al., 2007).

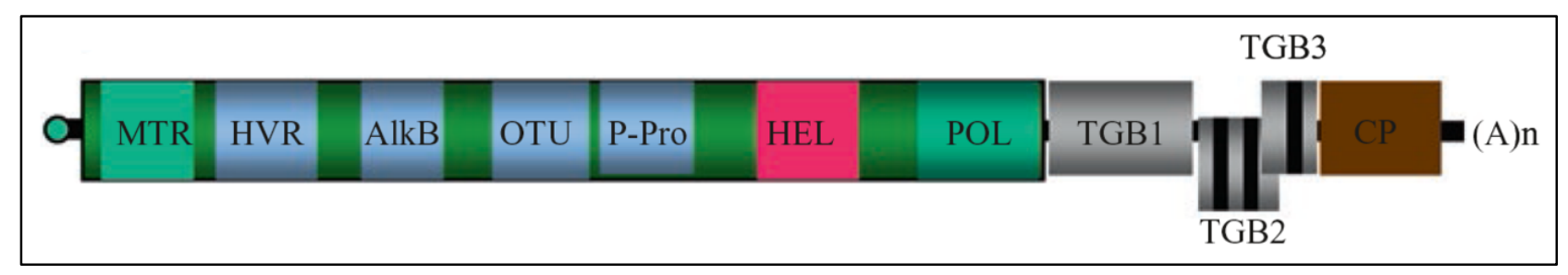

Figure 6 Representation of the complete GRSPaV genome. MTR, methyltransferase; HVR, highly variable region, AlkB, alkylation B; OTU, ovarian tumour-like cysteine protease; P-Pro, papain-like cysteine protease; HEL, helicase; POL, RNA-dependent RNA polymerase; TGB, triple gene block; CP, capsid protein (Meng and Rowhani, 2017).

The triple gene block (TGB1, TGB2 and TGB3) comprises ORFs 2, 3 and 4, and is observed in members of the genera Foveavirus and Carlavirus. The protein products are thought to facilitate cellto-cell movement of the virus (Morozov and Solovyev, 2003; Verchot-Lubicz, 2005). The $25 \mathrm{kDa}$ protein produced by TGB1 is distributed within the cytoplasm and nucleus of the cell and is involved with modification of the plasmodesmata to allow active transport of developing viral particles. TGB2 and TGB3 encode for 13 and $9 \mathrm{kDa}$ proteins, respectively, containing transmembrane domains and localisation signals targeted towards the endoplasmic reticulum (Rebelo et al., 2008). The $28 \mathrm{kDa}$ viral capsid protein (CP) is encoded by ORF 5 and is localised towards the nucleus of infected cells, however, the biological significance of this localisation signal remains to be elucidated (Meng et al., 2003; Meng and Li, 2010; Minafra et al., 2015; Petrovic et al., 2003; Poojari et al., 2013). ORF 6 (nt 8227-8586) overlaps with the CP region, and encodes a $14 \mathrm{kDa}$ protein of unknown function (Zhang et al., 1998). 


\subsubsection{Genetic diversity and population structure}

GRSPaV occurs as a large family of sequence variants and is known as one of the most molecularly differentiated viruses among the grapevine-infecting viruses (Meng et al., 2013; Meng and Rowhani, 2017). The initial sequencing of its complete genome by two independent research groups in 1998 (Meng et al., 1998; Zhang et al., 1998) lead to the development of RT-PCR-based methods for the detection and classification of GRSPaV. Currently, 20 complete or near complete GRSPaV genomes have been sequenced using cDNA library preparation and RT-PCR, RT-PCR exclusively and, most recently, next-generation sequencing (NGS) (Table 2). Nineteen of these genomes are available on GenBank. The majority of isolates were obtained from cultivars of Vitis vinifera, although some originated from other species. Sequences of the coat protein ORF and a segment of the replicase polyprotein domain containing the RNA helicase and RdRP-coding regions are used for the detection and classification of GRSPaV variants in most studies (Meng et al., 2005, 1999b; Terlizzi et al., 2011, 2010). These domains contain areas of high sequence similarity for broad spectrum detection, but are diverse enough to classify sequences into distinct phylogenetic groups. However, differences in tree topologies generated from the two respective regions have been observed (Alabi et al., 2010; Hu et al., 2015; Meng and Rowhani, 2017).

Multiple systems for the naming of phylogenetic groups have been proposed in literature. Initially, variant groups were named after a designated whole genome representative sequence from each group (Meng et al., 2006). Thereafter, two additional systems based on Arabic and Roman numerals were used (Hu et al., 2015; Nakaune et al., 2008; Nolasco et al., 2006). Finally, a system unifying the nomenclature of all genetic variants was proposed (Meng and Rowhani, 2017). The most recent system is in accordance with Meng et al. (2006) and the names of variant groups are based on a whole genome reference sequence of each cluster. Genetic diversity of GRSPaV and the use of this system is illustrated in two phylogenetic topologies generated from sequences of the RdRP and coat protein ORF regions, respectively (Figures 7 and 8). 


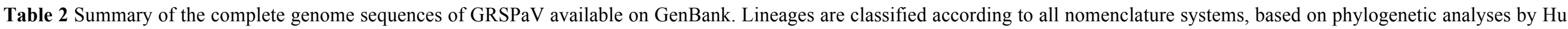
et al. (2015) and Meng and Rowhani (2017).

\begin{tabular}{|c|c|c|c|c|c|c|c|c|}
\hline $\begin{array}{l}\text { GenBank } \\
\text { accession } \\
\text { number }\end{array}$ & $\begin{array}{l}\text { Isolate title } \\
\text { (Meng and } \\
\text { Rowhani, 2017) }\end{array}$ & Abbreviation in this study & $\begin{array}{l}\text { Country of } \\
\text { origin }\end{array}$ & $\begin{array}{l}\text { Lineage based } \\
\text { on complete } \\
\text { genome (Hu et } \\
\text { al., 2015) }\end{array}$ & $\begin{array}{l}\text { Lineage based on } \\
\text { coat protein } \\
\text { ORF (Meng and } \\
\text { Rowhani, 2017) }\end{array}$ & $\begin{array}{l}\text { Lineage based on } \\
\text { RdRP (Meng } \\
\text { and Rowhani, } \\
\text { 2017) }\end{array}$ & $\begin{array}{l}\text { Lineage } \\
\text { corresponding } \\
\text { to Nolasco et } \\
\text { al. }(2006) \text { and } \\
\text { Nakaune et al. } \\
(2008) \\
\end{array}$ & Reference \\
\hline AY368590.1 & "GRSPaV-SY & 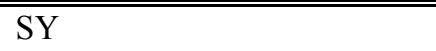 & "USA &  & "GRSPaV-SY & GRSPaV-SY & 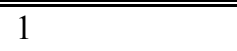 & "Lima et al. (2006a) \\
\hline KX274275.1 & n.a. & SK704-B & Slovakia & I & n.a. & n.a. & 1 & Glasa et al. (2017) \\
\hline AF057136.1 & GRSPaV-1 & GRSPaV & USA & IIa & n.a. & GRSPaV-1 & $2 b$ & Meng et al. (1998) \\
\hline JQ922417.1 & GRSPaV-GG & GG & USA & IIa & GRSPaV-1 & GRSPaV-1 & $2 b$ & Meng et al. (2013) \\
\hline HE591388.1 & GRSPaV-PG & PG & Italy & IIa & GRSPaV-1 & GRSPaV-1 & $2 b$ & $\begin{array}{l}\text { Giampetruzzi et al. } \\
(2012)\end{array}$ \\
\hline AF026278.1 & GRSPaV-CA & $\mathrm{RSPaV}$ & USA & IIa & n.a. & n.a. & $2 b$ & Zhang et al. (1998) \\
\hline KR528585.1 & n.a. & Tannat & Uruguay & IIa & GRSPaV-1 & n.a. & $2 b$ & $\begin{array}{l}\text { Cho et al. (2015) } \\
\text { (Unpublished) }\end{array}$ \\
\hline AY881626.1 & GRSPaV-SG1 & SG1 & USA & $\mathrm{IIb}$ & GRSPaV-SG1 & GRSPaV-SG1 & $2 \mathrm{a}$ & Meng et al. (2005) \\
\hline FR691076.1 & GRSPaV-MG & MG & Italy & $\mathrm{IIb}$ & GRSPaV-SG1 & GRSPaV-SG1 & $2 \mathrm{a}$ & Morelli et al. (2011) \\
\hline JX559646.1 & GRSPaV-3138-07 & $3138-07$ & Canada & $\mathrm{IIb}$ & GRSPaV-SG1 & GRSPaV-SG1 & $2 \mathrm{a}$ & $\begin{array}{l}\text { Rott and Belton (2012) } \\
\text { (Unpublished) }\end{array}$ \\
\hline KX274276.1 & n.a. & SK704-C & Slovakia & $\mathrm{IIb}$ & n.a. & n.a. & $2 \mathrm{a}$ & Glasa et al. (2017) \\
\hline AY881627.1 & GRSPaV-BS & $\mathrm{BS}$ & Canada & IIc & GRSPaV-BS & GRSPaV-BS & $2 \mathrm{a}$ & Meng et al. (2005) \\
\hline KX274277.1 & n.a. & SK30 & Slovakia & IIc & n.a. & n.a. & $2 \mathrm{a}$ & Glasa et al (2017) \\
\hline KR054734.1 & GRSPaV-JF & $\mathrm{JF}$ & China & III & GRSPaV-BS & GRSPaV-JF & 3 & Hu et al. (2015) \\
\hline AY368172.2 & GRSPaV-PN & PN & USA & III & GRSPaV-PN & GRSPaV-PN & 3 & Lima et al. (2009) \\
\hline KX274274.1 & n.a. & SK704-A & Slovakia & III & n.a. & n.a. & 3 & Glasa et al. (2017) \\
\hline KR054735.1 & GRSPaV-LSL & LSL & China & IV & GRSPaV-LSL & GRSPaV-LSL & n.a. & Hu et al. (2015) \\
\hline KT948710 & GRSPaV-VF & VF (not included in analyses) & Unknown & n.a. & GRSPaV-BS & GRSPaV-ML & n.a. & $\begin{array}{l}\text { Fajardo and Nickel } \\
\text { (2015) (Unpublished) }\end{array}$ \\
\hline Unavailable & GRSPaV-JH & $\mathrm{JH}$ (not included in analyses) & Unknown & n.a. & GRSPaV-SY & n.a. & n.a. & Hooker (2017) \\
\hline
\end{tabular}




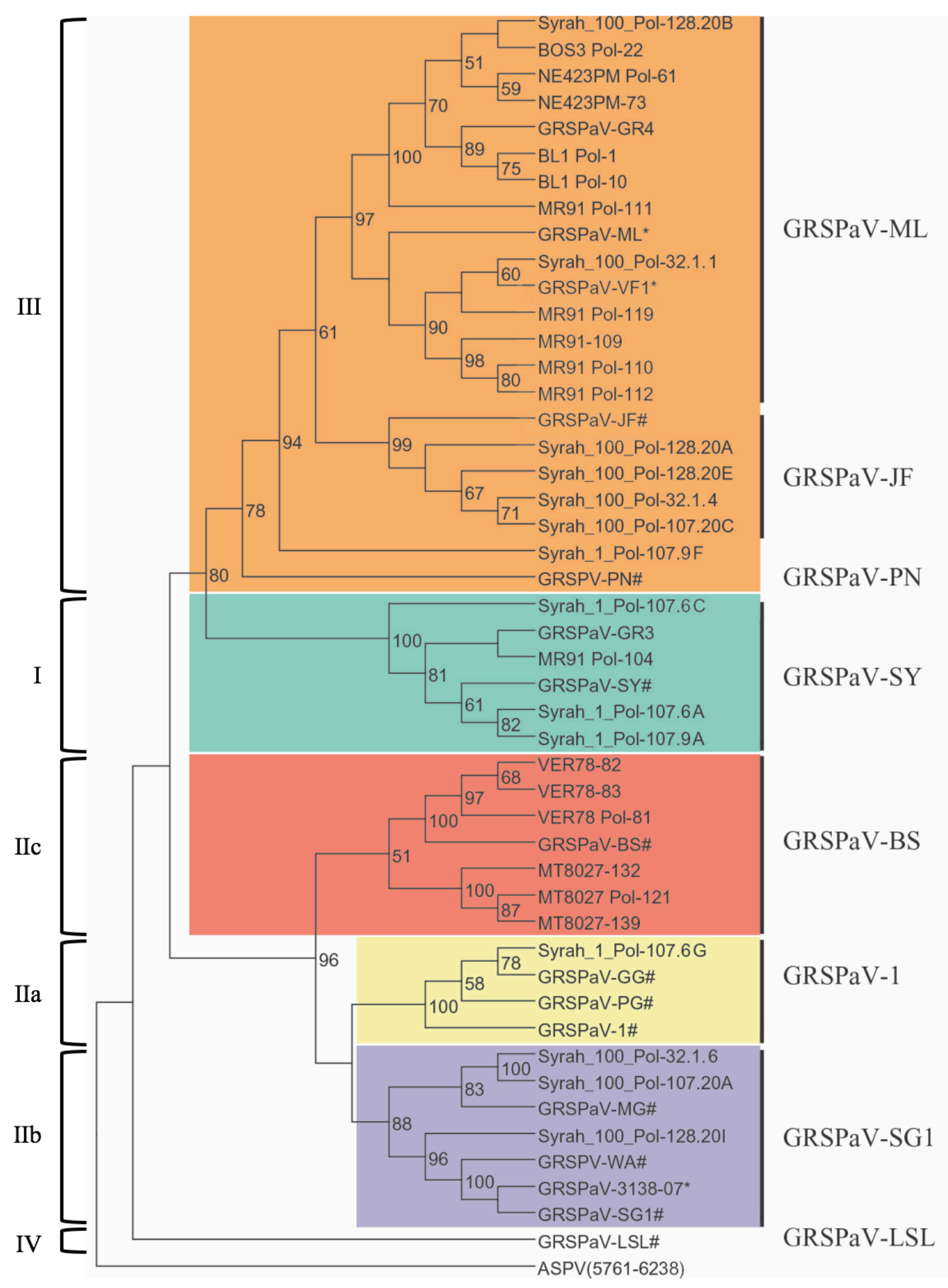

Figure 7 Phylogenetic tree of GRSPaV sequence variants based on a partial sequence of the RdRP region of the replicase polyprotein amplified by broad spectrum primers RSP35 and RSP36. Sequences derived from whole genomes are indicated with hash signs (\#). Sequences for which a partial genome was available, are indicated with an asterisk (*). A sequence of the corresponding region from ASPV (Apple stem pitting virus, D21829) was used as an outgroup. Phylogenetic analyses were performed using the Neighbour Joining algorithm. Nodes with bootstrap values of less than 50\% were collapsed (Meng and Rowhani, 2017). Corresponding lineages according to Hu et al. (2015) are indicated on the left. 


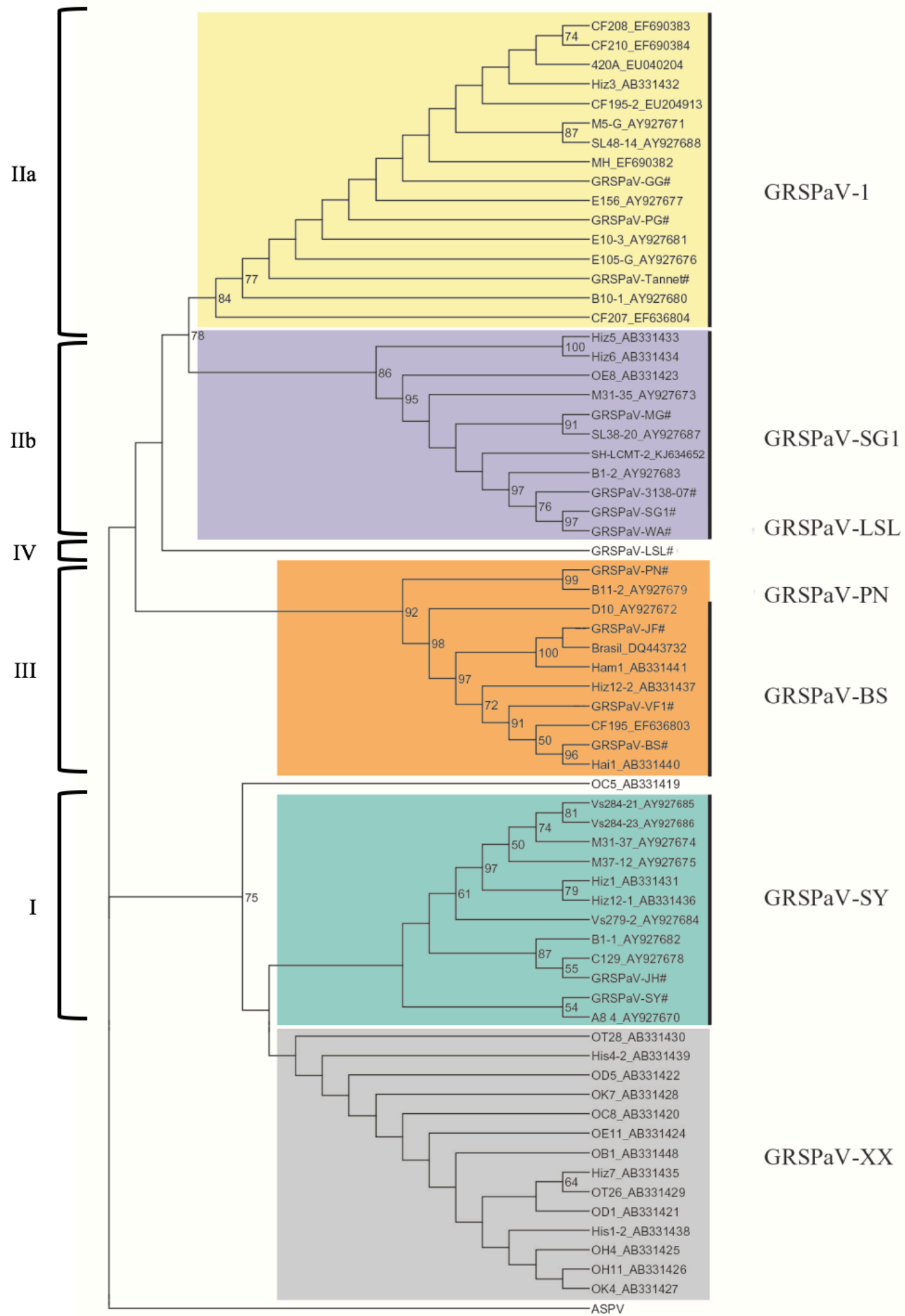

Figure 8 Phylogenetic tree of GRSPaV sequence variants based on nucleotide sequences of the coat protein gene. Sequences derived from whole genomes are indicated with hash signs (\#). A sequence of the corresponding region from ASPV (Apple stem pitting virus, D21829) was used as an outgroup. Phylogenetic analyses were performed using the Neighbour Joining algorithm. Nodes with bootstrap values of less than 50\% were collapsed (Meng and Rowhani, 2017). Corresponding lineages according to $\mathrm{Hu}$ et al. (2015) are indicated on the left. 
The unification of the newly proposed reference-based system to the two numeral-based systems is complicated by several factors. The clustering of whole genome reference sequences GRSPaV-JF, GRSPaV-VF1 and GRSPaV-BS are not consistent between the two topologies constructed by Meng and Rowhani (2017). Variant groups GRSPaV-XX and GRSPaV-ML were proposed, but no complete genome sequences to be used as references for the two groups have been sequenced. The sequences of some isolates included in these trees are not yet available on GenBank, and there is a lack of information on the origin of other sequences in these topologies. Furthermore, the use of a recombinant sequence (GRSPaV-BS, Glasa et al., 2017) as a designated representative when recombinants are known to group inconsistently in phylogenetic trees (Martin et al., 2015) may cause confusion. Finally, the exclusion of some reference sequences from the trees constructed by Meng and Rowhani (2017) also caused difficulties in determining the classification of all genomes corresponding to the other nomenclatures. Due to all the shortcomings listed above, the roman numeral-based nomenclature (Glasa et al., 2017; Hu et al., 2015) was used throughout the present study. Four major phylogenetic groups (I, II, III and IV) are recognised, with group II being further subdivided into subgroups IIa, IIb and IIc. Each variant group is represented by the complete genome of one or more isolates. For the purpose of unification, the classification of reference sequences based on all available nomenclature schemes are summarised in Table 2.

As evidenced by the diverse origins of reference genomes, no apparent geographic clustering of GRSPaV variants has been observed (Alabi et al., 2010; Nolasco et al., 2006). However, distinct virus population structures have been observed in scion varieties compared to rootstock varieties. Mixed infections with divergent variants are often more common in scion varieties, whereas rootstock varieties generally contain a homogenous population of a single variant group. Furthermore, some variant groups are more closely associated with specific Vitis species. The majority of the infected rootstock species $V$. riparia and its hybrids contain viruses from phylogroup IIa, whereas group IIb are more commonly detected in $V$. rupestris. This provides possible evidence of co-evolution and divergence of GRSPaV and its grapevine host. It is also possible that GRSPaV initially infected members of $V$. vinifera, and distinct variants were then transmitted horizontally to rootstock varieties by humans or insect vectors (Meng et al., 2006).

\subsubsection{Diseases associated with GRSPaV}

Infection with GRSPaV often does not elicit any symptoms. In cases where symptoms are expressed, the severity and nature of symptoms varies greatly on the rootstock and scion cultivar combination. Symptom expression is further influenced by several biotic and abiotic factors, including microbial 
pathogens present in the plant, minerals present in the soil, soil moisture and seasonal changes (Lima et al., 2009). Combinations of different viruses or viral strains also cause diseases or disease complexes. Although different GRSPaV variant groups are reported to be associated with certain diseases or symptoms, difficulties in fulfilling Koch's postulates has complicated the establishment of the exact aetiological role of each variant in specific disorders (Bouyahia et al., 2005; Habili et al., 2006; Lima et al., 2006a; Meng et al., 2005, 1999a, 1999b; Meng and Gonsalves, 2007; Zhang et al., 1998). The presence of multiple variants in single plants and mixed infection with other pathogens have further complicated this process (Prosser et al., 2007). An infectious clone of GRSPaV-GG (group IIa) has been synthesised for utilisation in further studies. However, clones of more pathogenic variants are needed to elucidate the disease-causing properties of the respective viral variants (Meng et al., 2013).

\subsubsection{Rupestris stem pitting}

The biological association of GRSPaV with Rupestris stem pitting (RSP), one of the more commonly observed syndromes of RWD, is frequently reported (Meng and Gonsalves, 2007). The existence of RSP has been revealed via indexing on a biological indicator in Germany, France, Australia, South Africa, California, Mexico, Italy and China (Conti et al., 1980; Engelbrecht and Nel, 1971; Goheen, 1989; Hewitt and Neja, 1971; Li et al., 1989; Teliz et al., 1980). Since the introduction of routine RTPCR diagnostic assays, detections in other countries such as Turkey and Slovakia have been reported (Buzkan et al., 2015; Glasa et al., 2017). Typical symptoms of RSP are basipetal pitting and grooving on the stem from the point of inoculation due to xylem modifications occurring as a result of viral infection (Figure 4D) (Martelli et al., 2007). No extreme reddening or yellowing on the foliage is observed, however, a slight pink discoloration has been reported. The disease is associated with stunting, a slow decline and eventual death of infected vines. Delayed ripening and a low sugar content of berries ultimately lead to a decrease in yield and grape quality (Goheen, 1989; Martelli, 2014; Meng and Gonsalves, 2007).

Variants from groups I and IIc are associated with RSP symptoms on V. vinifera (Habili et al., 2006). Infection with variant IIa is asymptomatic on V. rupestris St. George, the biological indicator for RSP, whereas presence of GRSPaV IIb variants elicits mild or no symptoms on this cultivar (Meng et al., 2005). However, in field plants infected with GRSPaV IIa, a statistically significant decrease in yield, bunch size, berry size and weight, total soluble solids and acidity levels is reported (Meng et al., 2005). These changes are consistent with those observed in plants with RSP disease. An overlap of upregulated genes between GRSPaV-infection and abiotic stresses such as drought and salinity 
was detected. Furthermore, GRSPaV-infected grapevines appeared to be more sensitive to environmental changes. Grapevines with viral diseases often show a severe decrease in levels of photosynthesis, however, transcriptomic analyses of GRSPaV IIa-infected plants have indicated an increase in expression of some genes involved in $\mathrm{CO}_{2}$ fixation and photosynthesis. The upregulation of these genes are not enough to combat the overall decrease in levels op photosynthesis, although it is speculated that the less severe effects of GRSPaV-infections compared to those of GLRaVs could be linked to a long co-existence of GRSPaV and its host (Gambino et al., 2012).

\subsubsection{Syrah decline}

Syrah decline (SD) is prevalent worldwide, and has been reported in France, Australia, South Africa, USA and Canada (Habili et al., 2006; Lima et al., 2006a; Meng et al., 2013; Renault-Spilmont et al., 2003), but has only been observed in $V$. vinifera cv. Syrah (synonym Shiraz). Symptoms include weak growth, premature reddening of leaves and unripe berries with poor colour and low sugar content, causing a reduction in wine quality. Deep grooving on the stems of scions is observed, with swelling and cracking at the graft union (Figure 9). Symptoms are not observed on rootstock cultivars, however, a reduction in vigour due to graft failure leads to a lower fruit yield. Grapevines exhibiting graft-associated symptoms may survive, but cultivars in which leaves are reddened as a result of infection, ultimately decay (Battany et al., 2004; Beuve et al., 2013; Lima et al., 2006a; RenaultSpilmont et al., 2003; Stamp, 2004).

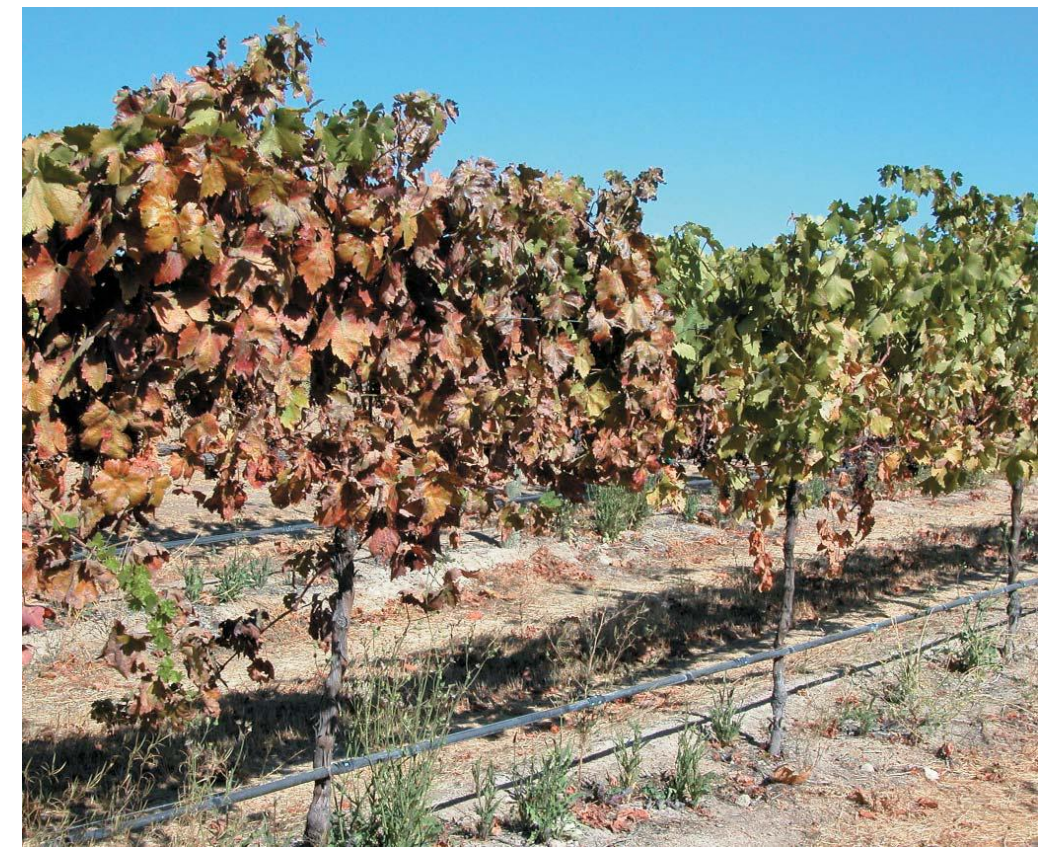

Figure 9 Premature reddening of leaves as a result of Syrah decline (left) compared to an unaffected vine (right) (Battany et al., 2004). 
The exact cause of SD has not been identified. It is speculated that genetic incompatibility between scion and rootstock, and mixed infection by multiple viruses and other pathogens plays a role in the onset of this disease. Furthermore, a correlation between symptoms and climate, soil or pathogens could not be established, and the possibility that the disease is an adverse reaction of Syrah vines to herbicides has been investigated (Al Rwahnih et al., 2009; Golino, 1993; Stamp, 2004; Steenwerth et al., 2007). Initially, GRSPaV group I was thought to be more strongly associated with the disease than other variants, as it was the most prevalent variant detected in grapevines showing symptoms of SD (Beuve et al., 2009; Bianco et al., 2009; Habili et al., 2006; Lima et al., 2006a). However, in 2010, five molecular strains of GRSPaV were detected in grapevine clones regardless of their SD status, therefore no correlation between GRSPaV and SD could be established (Goszczynski, 2010). In a more recent study, GRSPaV from all phylogenetic groups were detected in 100\% of Syrah clones with varying sensitivity to SD (Beuve et al., 2013). A combination of GRSPaV with two other viruses, Grapevine rupestris vein-feathering virus and Grapevine Syrah virus-1, together with several other biotic and abiotic factors, is speculated to be the main infectious agents causing this disease (Hooker, 2017).

\subsubsection{Grapevine vein necrosis}

GRSPaV group I and subgroups of II are the putative causative agents of Grapevine vein necrosis (GVN), a disease reported in Europe, Australia, Brazil and USA (Martelli and Boudon-Padieu, 2006). GVN is latent in most Vitis species, and symptoms are only elicited on rootstock indicator 110R ( $V$. rupestris $\mathrm{X} V$. berlandieri) six to eight weeks after inoculation. Typical symptoms of GVN infection are an appearance of necrosis of veinlets on the lower side of leaf blades and deceased tendrils and shoots (Figure 10). Growth of infected plants are reduced or completely terminated, leading to ultimate death of the vine (Bouyahia et al., 2009, 2006a, 2006b, 2005; Martelli and Boudon-Padieu, 2006).

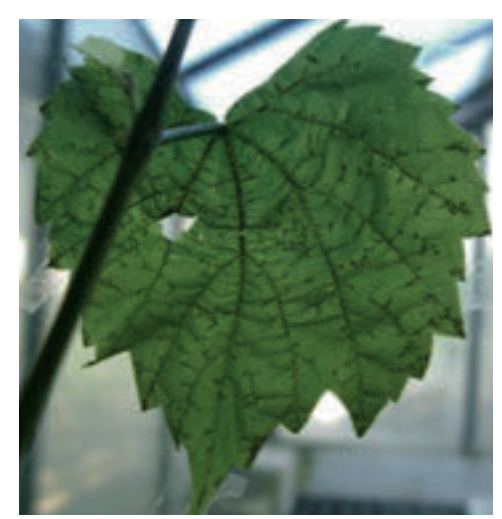

Figure 10 Grapevine vein necrosis in Richter 110R. Image courtesy of D. Boscia, (Meng and Rowhani, 2017). 


\subsubsection{Transmission of GRSPaV}

Grafting between scions and rootstocks, and vegetative propagation of inadequately sanitised material are the main means of transmission and spread of GRSPaV (Meng and Gonsalves, 2007). The possibility of transmission through pollen has been reported (Rowhani et al., 2000). Furthermore, GRSPaV has been detected in seeds (Stewart and Nassuth, 2001) and a small percentage of seedlings from seeds collected from GRSPaV-infected plants, indicating another possible means of transmission (Lima et al., 2006b). To date, no natural insect vector for GRSPaV has been reported.

\subsubsection{Detection of GRSPaV}

Reliable detection of grapevine viruses plays a crucial role in the prevention and control of economically important diseases. The production of virus-free plant material for propagation, and monitoring of the sanitary status of field vines to prevent secondary spread of diseases, heavily rely on accurate and efficient detection tools (Al Rwahnih et al., 2015; Burger and Maree, 2015; Martelli, 2014; Roossinck et al., 2015). Great advances have been made in the development of diagnostic and detection tools for GRSPaV, however, the commercial implementation of these methods is limited (Basso et al., 2014, 2017).

\subsubsection{Biological indexing}

Currently, hardwood indexing is the primary method of diagnosis used to monitor the status of field vines and to verify the fulfilment of sanitary requirements by candidate mother plants. Although it is often used in combination with RT-PCR, it cannot yet be completely replaced by primer-based, virus specific assays as the exact pathological agents of some diseases have not been determined (Al Rwahnih et al., 2012; Meng and Rowhani, 2017). Since GRSPaV is not sap-transmissible, bud chips from accessions of interest are graft-inoculated onto a panel of own-rooted grapevine selections on which the symptom expression is known. Pitting and grooving on the stem of $V$. rupestris St. George are indicators of RSP, whereas LN 33 and Kober 5BB show no signs of infection (Martelli, 2014; Martelli et al., 1993). Hardwood indexing is useful for diagnosing diseases such as RSP for which the aetiology is not well-characterised. However, visual diagnosis is often complicated by varying degrees of symptom expression due to environmental effects and the presence of multiple pathogens within a single plant. Consequently, expert staff is required to distinguish between diseases or syndromes. Bioassays are also labour intensive, and require a large amount of space (Al Rwahnih et 
al., 2015). In the case of RSP, symptoms are only detectable two to three years after grafting, rendering this method extremely time-consuming and costly (Martelli, 2014; Martelli et al., 1993).

\subsubsection{Serological methods}

Serological methods for the detection of GRSPaV in field-collected material have shown limited success. Several polyclonal antibodies have been developed for the use in Western blotting and enzyme-linked immunosorbent assays (ELISAs) (Basso et al., 2010; Meng et al., 2003; Minafra et al., 2015). These methods are more rapid than biological indexing, but are limited to specific viruses and will therefore not be efficient at detecting diseases for which the associated infectious agents are not known. The high background noise observed with ELISAs made it difficult to distinguish between weekly positive samples and samples that were free of GRSPaV (Meng et al., 2003). Western blotting also proved efficient at detecting GRSPaV, however, varying titres under field conditions complicated detection. Expression of the capsid protein greatly varied based on the genetic make-up of cultivars, types of tissue tested, and climate (Meng et al., 2000; Meng and Gonsalves, 2003; Minafra et al., 2015). Antiserums for GRSPaV continue to be developed and tested (Basso et al., 2010), but no serological assay has been successful enough to be commercially implemented on a global level.

\subsubsection{Nucleic-acid based detection methods}

Nucleic-acid based detection methods are widely used for the detection of GRSPaV as they are more sensitive and effective than serological assays or biological indexing (Meng and Rowhani, 2017). RT-PCR or RT-qPCR assays overcome some of the problems encountered with the other methods, as they are more sensitive to detect latent infections and are not severely affected by seasonal variation of antigen expression (Meng and Rowhani, 2017). However, these methods rely heavily on the sensitivity of the primers used. With the accumulation of more sequence data, primer sets are continuously improved to detect a wider range of genetic variants. A wide variety of primer sets targeting the capsid protein and parts of the replicase polyprotein sequence have been designed for GRSPaV detection (Alabi et al., 2010; Bouyahia et al., 2006a, 2005; Buzkan et al., 2015; Habili et al., 2006; Lunden et al., 2010; Meng et al., 2006, 2003; Nolasco et al., 2000; Rowhani et al., 2000; Terlizzi et al., 2011, 2010; Zhang et al., 1998). These primers showed varying levels of efficiency in detecting multiple strains, which lead to the development of a set of degenerate primers (RSP35 and RSP36, Terlizzi et al., 2011) based on the consensus sequence of GRSPaV and other members of the genera Foveavirus and Carlavirus. Although RSP35 and RSP36 detect all variants of GRSPaV, they 
are not specific to this virus and should be used with caution. When using universal primer sets, further cloning and sequencing are required to classify variants, specifically in the case of multivariant infections. Using different genomic areas for classification can also lead to inconsistencies (Alabi et al., 2010; Meng and Rowhani, 2017). Co-purified inhibitors in RNA extracts from woody plants can affect nucleic-acid based detection methods. Specific protocols for the isolation and purification of nucleic acids from grapevines have been proposed, however, the protocols are not equally efficient at extracting high quality RNA from all tissue types (Xiao et al., 2015). A low virus titre and a suspected uneven localisation in the plant, especially during early stages of infection, can also lead to unreliable detection via RT-PCR or RT-qPCR (Basso et al., 2010; Beuve et al., 2007; Meng et al., 2013).

\subsubsection{Next-generation sequencing}

Next-generation sequencing (NGS) is a promising but under-utilised technology for the identification of viruses and other pathogens in putatively infected samples. It requires no background knowledge of specific causative agents, and involves the sequencing of all DNA or RNA from a sample. Sequence identity searches through read-mapping to reference data, or BLAST analysis of read data or de novo assembled reads, can then be used to characterise the microbiome of the sample. It is rapid, unbiased, not limited by strain differences or the occurrence of asymptomatic infections, and has the ability to screen for multiple pathogens simultaneously, detecting both known and novel viruses, fungi, and bacteria. A recent study has proven that NGS is as effective or superior as biological indexing at identifying GRSPaV in a test sample (Al Rwahnih et al., 2015). Due to the sensitivity of NGS, it is not affected by a low virus titre, however, GRSPaV is unevenly distributed within organs and during different phenological phases. Furthermore, climate changes can influence the titre and distribution of GRSPaV in the plant.

This can lead to inconsistencies in virus detection, especially during early stages of infection (Meng et al., 2013). Assembly of reads from viruses or virus variants with similar genome sequences can also lead to the creation of artificial recombinant sequences, and further cloning and sequencing would be required to confirm the existence of naturally occurring recombinant genomes (Hu et al., 2015; Meng and Rowhani, 2017). Due to the expense of NGS, uptake on a commercial level has been limited. 
Although some GRSPaV infections are latent in Vitis rupestris, GRSPaV in combination with other viruses such as GVA are not. Therein lies the risk for the development of more severe disease complexes when symptomless vines are cultivated and viruses spread through grafting or via insect vectors (Bonfiglioli et al., 1998). To eliminate GRSPaV from infected clones for the production of virus-free propagating material, several techniques have been proposed. Meristem tip culture has been successfully applied to eliminate closteroviruses from infected material, but has proven to be the least efficient means of removing GRSPaV from field-collected woody cuttings (Gribaudo et al., 2006; Habili et al., 1992; Minafra and Boscia, 2003). In vivo and in vitro thermotherapy are also widely used to eliminate GRSPaV from plant material. Although slightly more effective than meristem tip culture, both these methods were successful in less than $25 \%$ of cases (Gribaudo et al., 2006). Regeneration through somatic embryogenesis using immature anthers and ovaries collected from blossoms in the field has been the most successful technique for the elimination of GRSPaV (Gribaudo et al., 2004). However, the success rate of the process is possibly cultivar dependent, and somaclonal variation could be induced (Gribaudo et al., 2006). It is also time-consuming and technically difficult, therefore reliant on skilled personnel. Techniques such as cryopreservation and the use of antiviral compounds have been proposed for the elimination of other viruses (Panattoni et al., 2006; Wang et al., 2003), but remain to be applied to and evaluated for GRSPaV (Gribaudo et al., 2006).

\subsection{Recombination}

Recombination in viruses has been linked to an increase in virulence, evasion of host immunity, and an increase in resistance to antiviral agents (Nagy, 2008; Simon-Loriere and Holmes, 2011). RNA recombination is defined as the exchange of RNA fragments between RNA molecules and can occur naturally or under experimental conditions. In RNA viruses, recombination between identical or nonidentical viruses or strains is a mechanism to generate genetic variability. Recombination can also occur between viral and cellular RNAs, leading to functional or non-functional RNA molecules or to the intake of host genetic material by the virus (Bujarski, 2013).

The majority of RNA recombination occurs during the process of replication, where the viral RNAdependent RNA polymerase (RdRP) changes templates during RNA synthesis (Galetto et al., 2006). Sites with high recombination activity (referred to as recombination hotspots) occur in areas with large sequence homologies, areas where transcription factors are located or localised towards, or at 
the ends of RNA molecules where termination signals are located (Fajardo et al., 2012; Nagy et al., 1999; Wierzchoslawski et al., 2004). Secondary structures of RNA molecules may also play a role, as interaction or hybridisation between mature RNA molecules may bring certain regions close enough for the RdRP-enzyme to switch between molecules (Dzianott et al., 1995; Nagy and Bujarski, 1993). Non-replicative RNA recombination has been reported in other animal or human RNA viruses, most notably poliovirus (Gmyl et al., 1999). However, not much information is available on nonreplicative RNA recombination in plant viruses (Bujarski, 2013). Recombination rates are influenced by factors such as the strength of binding of the viral RdRP, or the localisation of the replication site in the cell. It is speculated that some RNA viruses replicate in spherules. These membrane structures are packed tightly with viral proteins, viral genomic RNAs and host factors required for replication (Laliberté and Sanfaçon, 2010; Mine and Okuno, 2012). The close proximity of the molecules allows for recombination to take place.

Artificial recombination can occur in vitro when partially homologous templates are present in a single PCR. To reduce the formation of chimeric molecules resulting from the switching of the polymerase enzyme between non-identical templates during the course of a PCR, concentration of the initial template can be lowered. Furthermore, the amount of cycles should be kept at a minimum. Finally, PCR-mediated recombination can be limited by using high-fidelity, proofreading polymerase enzymes (Judo et al., 1998; Lahr and Katz, 2009; Meyerhans et al., 1990; Odelberg et al., 1995). The formation of chimeric contiguous sequences is also possible during assembly of NGS reads from partially homologous sequences present in a single sample. To avoid this, the stringency of sequence assembly parameters can be altered. Cloning and sequencing of cDNA fragments used in genome assembly can confirm whether chimeric sequences are naturally occurring or sequencing artefacts (Meng and Rowhani, 2017).

\section{6}

\section{Conclusion}

The prosperity of the grapevine industry is threatened by diseases, some of which are caused by grapevine-infecting viruses. GRSPaV is associated with Rupestris stem pitting, Syrah decline and Grapevine vein necrosis, three diseases with the potential to cause a reduction in economic return from affected crops. The exact aetiological role of GRSPaV remains to be described, and is further complicated by inconsistent classification and variable symptom expression between viral variants and host cultivars. Furthermore, the practice of grafting causes transmission of variants between scion and rootstock cultivars and has led to multiple variant infections of GRSPaV. Recombination has been detected in the coat protein ORF and replicase regions of the GRSPaV genome (Alabi et al., 
2010; Glasa et al., 2017) and has lead to inconsistencies in variant classification (Alabi et al., 2010). The optimisation of variant detection and classification could provide valuable information on the evolution and epidemiology of this virus.

The aim of this project was to characterise the genetic diversity of GRSPaV in three surveys, and to investigate the effect of recombination and the use of different genomic regions on variant classification. 


\section{Chapter 3: Materials and methods}

\section{1}

\section{Source material}

To investigate global GRSPaV diversity a survey (NV) was carried out on a grapevine cultivar repository maintained by the Agricultural Research Council Infruitec-Nietvoorbij in Stellenbosch, South Africa in March 2015. Grapevines in the repository originated from various countries and were collected prior to phytosanitary regulation. The repository is arranged into rows divided into bays (accessions) containing between one and six plants from a specific source. Because no biological vector for GRSPaV has been reported and the virus is not mechanically transmissible (Minafra and Boscia, 2003), it was assumed that no transmission occurred within the repository and the accessions therefore represent the global distribution of the virus. Petiole material was collected individually from all plants in 54 bays spaced evenly throughout the vineyard and pooled for each respective accession prior to RNA extraction. Five additional accessions in which GRSPaV has previously been detected were sampled as positive controls. Virus-free cane material was obtained from an uninfected Vitis vinifera cv. Chenin Blanc (rootstock: Richter 99) vine collected from a certified virus-free nursery and maintained in the greenhouse (Stellenbosch University, South Africa), for use as a negative control.

Two additional surveys were conducted in March 2016 on collections of South African vineyards to investigate local virus diversity. The first was carried out on mother blocks (MB) that previously conformed to South African certification requirements but are no longer used for vine propagation due to GLD infection. Cane material was collected from 176 individual plants distributed among 19 mother blocks on four wine estates situated in and around Stellenbosch. A final survey (OV) constituted South African vineyards that were established prior to the implementation of current sanitary protocols. Samples in the form of cane material were collected from a total of 117 individual plants among 23 vineyards on 10 wine estates located in the Stellenbosch, Citrusdal and Clanwilliam areas of South Africa. Phloem shavings from the canes of each sample were collected.

The majority of grapevines sampled were from the species Vitis vinifera, although some of the global repository accessions (NV survey) were interspecific crosses between Vitis vinifera and Vitis labrusca. Bays within the cultivar repository were selected for sampling based on the exhibition of typical symptoms of virus infection, whereas presence of symptoms were not taken into consideration during sampling in the MB and OV surveys. 
A cetyltrimethylammonium bromide (CTAB) method (White et al., 2008) was used to isolate high quality total RNA from $2 \mathrm{~g}$ of pooled petioles or $2 \mathrm{~g}$ of phloem scrapings from each accession or plant within the global (NV) and local old vine (OV) surveys, as well as the controls. High molecular weight (HMW) RNA was isolated from $2 \mathrm{~g}$ of phloem scrapings from each mother block (MB) survey sample using another CTAB method (Carra et al., 2007). RNA quality from both methods was evaluated via gel electrophoresis on a 1.5\% TAE-Agarose gel and both quality and concentration were determined spectrophotometrically. Purified RNA was stored at $-80^{\circ} \mathrm{C}$.

\subsection{RT-PCR detection assays}

Based on the consensus sequence of $11 \mathrm{GRSPaV}$ complete genomes and $493 \mathrm{GRSPaV}$ coat protein genes available on GenBank, a primer set GRSPaV_DET (Table 3) was designed for the detection of a wide range of GRSPaV variants. The primer set amplified a 246 base pair (bp) fragment, partially overlapping with the coat protein gene, corresponding to nt 8391-8636 (GenBank accession AF057136). The specificity of the GRSPaV-DET was validated using Sanger sequencing of the amplicon. Depending on the sample type, complementary DNA (cDNA) was synthesised from 500 ng total RNA or 1000 ng HMW RNA, primed with 150 ng random hexadeoxynucleotides (Promega) using Maxima Reverse Transcriptase and Thermo Scientific RiboLock RNase Inhibitor (Thermo Fisher Scientific) according to manufacturer's instructions. Individual PCRs of $25 \mu 1$ each were then performed using KAPA Taq DNA Polymerase (Kapa Biosystems) according to manufacturer's instructions. Amplicons were separated and visualised on a 1\% TAE-Agarose gel. To confirm that all negative results were due to the absence of GRSPaV and not the consequence of a failed cDNA synthesis, cDNA from samples in which no GRSPaV was detected were subjected to a second round of PCR using ActinF and ActinR primers designed to differentiate between RNA transcripts (in this instance, cDNA) and genomic DNA of the Vitis actin gene (Reid et al., 2006).

\section{4}

Amplification, cloning and sequencing of two genomic regions of GRSPaV isolates

Two additional PCRs were performed on the cDNA from GRSPaV positive samples to amplify two genomic regions commonly used to classify GRSPaV variants. A 1668 bp area (nt 3438-5105, GenBank accession AF057136) within the replicase gene, hereafter referred to as $p R E P$, was amplified by primer set GRSPaV_PT_REP (Table 3). The primer set was designed based on the consensus sequence of $11 \mathrm{GRSPaV}$ whole genome sequences and 110 partial GRSPaV replicase ORF 
sequences available on GenBank. Additionally, primer set GRSPaV_CPORF (Table 3) was designed based on the consensus sequence of $11 \mathrm{GRSPaV}$ complete genomes and $493 \mathrm{GRSPaV}$ coat protein gene sequences from GenBank, and used to amplify CPreg, a 928 bp region (nt 7709-8636, GenBank accession AF057136) containing the complete coat protein open reading frame (ORF). Both primer sets were validated using amplicon sequencing. Using a KAPA HiFi PCR Kit (Kapa Biosystems), PCRs of $25 \mu \mathrm{l}$ each were performed on GRSPaV positive samples following the manufacturer's instructions. PCR products were separated by gel electrophoresis on a 1.8\% TAE-Agarose gel. Bands of the expected size were excised and purified using the Zymoclean Gel DNA Recovery Kit followed by d(A)-addition to purified amplification products according to manufacturer's instructions (Kapa Biosystems). Fragments were then cloned into the pGEM-T easy vector (Promega) in a final reaction volume of $5 \mu 1$ according to manufacturer's instructions. Resulting recombinant vectors were used to transform Escherichia coli JM109 cells (Sambrook et al., 1987). Recombinant clones were screened by a colony PCR using the SP6 and T7 promoter primers (Table 3) using KAPA Taq DNA Polymerase as described above. PCR amplicons were analysed on a 1.5\% TAE-Agarose gel. Colonies containing inserts of the expected size were inoculated individually in $5 \mathrm{ml} \mathrm{LB}$ broth (Merck Millipore) containing $100 \mu \mathrm{g}$ Ampicillin (Roche Life Science) and grown overnight at $37{ }^{\circ} \mathrm{C}$ with shaking. Plasmid DNA was purified from $2 \mathrm{ml}$ of each cell culture using the GeneJET Plasmid Miniprep Kit (Thermo Fisher).

Table 3 Summary of the primers used in this study. The name, sequence, annealing temperature $\left(\mathrm{T}_{\mathrm{A}}\right)$, extension time (Ext) and expected amplicon size is given.

\begin{tabular}{|c|c|c|c|c|c|}
\hline Name & Sequence & $\mathbf{T}_{\mathbf{A}}$ & Ext & $\begin{array}{l}\text { Amplicon } \\
\text { size (bp) } \\
\end{array}$ & Reference \\
\hline $\begin{array}{l}\text { GRSPaV Detection } \\
\text { (GRSPaV DET) }\end{array}$ & & $52^{\circ}$ & $30 \mathrm{~s}$ & 246 & This study \\
\hline GRSPaV_8391F & 5'-AACVAAAGCWGAGATGGT-3' & & & & \\
\hline GRSPaV_8619R & 5'-AGTACGGTATTCCAGCGA-3' & & & & \\
\hline Actin & & $55^{\circ}$ & $20 \mathrm{~s}$ & 82 (RNA) & Reid et al., \\
\hline ActinF & 5'-CTTGCATCCCTCAGCACCTT-3' & & & 156 (DNA) & 2006 \\
\hline ActinR & 5'-TCCTGTGGACAATGGATGGA-3' & & & & \\
\hline $\begin{array}{l}\text { GRSPaV Coat Protein } \\
(\text { GRSPaV CPORF })\end{array}$ & & $58^{\circ}$ & $60 \mathrm{~s}$ & 928 & This study \\
\hline 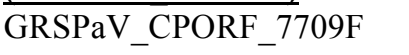 & 5'-TGAAGGCTTTAGGGRTTAG-3 & & & & \\
\hline GRSPaV_8619R & 5’-AGTACGGTATTCCAGCGA-3' & & & & \\
\hline $\begin{array}{l}\text { GRSPaV Replicase } \\
\text { (GRSPaV PT REP) }\end{array}$ & & $55^{\circ}$ & $90 \mathrm{~s}$ & 1668 & This study \\
\hline GRSPaV_PT_REP1_3438F & 5'-CTTATGCCGARAATGARATGAT-3' & & & & \\
\hline GRSPaV_PT_REP_5084R & 5'-GRTCACCACAHAACTTCTCCTC-3' & & & & \\
\hline pGEM-T Easy cloning site & & $55^{\circ}$ & $60 \mathrm{~s}$ & Insert +141 & Promega \\
\hline SP6 promoter & 5'-ATTTAGGTGACACTATAG-3' & & & & \\
\hline $\mathrm{T} 7$ promoter & 5'-TAATACGACTCACTATAGGG-3' & & & & \\
\hline
\end{tabular}


A minimum of three positive clones for each genome region from each sample were sequenced using the SP6 and T7 promoter primers. Sequence quality was evaluated, vector sequences removed and the forward and reverse sequences of each clone assembled with CLC Main Workbench V7.7.1 (CLC Bio-Qiagen, Aarhus, Denmark) using the corresponding area from the GRSPaV reference genome (AF057136). Assemblies were manually scanned for any misalignments, mismatches caused by repetitive nucleotides, or ambiguity caused by sequencing errors. Following manual correction of assemblies, a consensus sequence for each clone was constructed.

\subsection{Classification of whole genome reference sequences}

To serve as references, the $18 \mathrm{GRSPaV}$ whole genome sequences were obtained from GenBank. Additional sequence data from the coat protein or replicase genome areas generated in previous studies are available on the public database. However, these sequences were not considered to serve as references for phylogenetic groups, as not many studies provided sequences from both regions, nor confirmed that sequences from different regions originated from the same isolate. Furthermore, most of the sequences available only partially overlapped with the areas under investigation in this study and would cause a significant amount of missing data should they be included in the alignment. A large number of sequences available were short and therefore contained little phylogenetic signal. Phylogenetic analyses previously conducted on the whole genome sequences revealed that they cluster into four major phylogenetic groups (I-IV) with group II being further divided into subgroups IIa, IIb and IIc (Glasa et al., 2017; Hu et al., 2015). Sequences were aligned using the FFT-NS-1 strategy on MAFFT V7 (Katoh and Standley, 2013) with default parameters, and the alignment was manually refined in Mesquite V3.2 (Maddison and Maddison, 2017). Furthermore, the whole genome alignment was trimmed using CLC Main Workbench V7.7.1 (CLC Bio-Qiagen, Aarhus, Denmark) to produce two additional alignments containing only the regions of reference sequences corresponding to CPreg and $p R E P$, respectively.

A recombination analysis was performed on the whole genome alignment using RDP4 V8.20 (Martin et al., 2015). Sequences were defined as linear and the highest acceptable P-value left at 0.05, as recommended in the user manual. Topological evidence was required to allow manual refinement of recombinants. The polishing of breakpoints was also left on, as analyses are more accurate with this setting activated. Preliminary scans were performed using RDP, MaxChi and Chimaera, and secondary scans were performed using BootScan and SiScan. The window size was set to 392 (approximately 10\% of the number of variable sites) for RDP. For BootScan and SiScan, a window size of 876 (approximately $10 \%$ of the total length) and a step size of 438 (50\% of the window size) 
was used. Variable window sizes for MaxChi and Chimaera were set at a fraction of 0.1 of variable sites per window. Disentanglement of overlapping signals was not required, as secondary recombination events are not impossible and this setting is recommended for datasets where recombination is relatively rare. Recombinants were grouped realistically rather than conservatively, as the recombination signals of multiple sequences from the same event were manually inspected to determine whether they were identical; it is easier to separate sequences from a single event than to combine sequences from multiple events. Preliminary results were manually refined as instructed in the manual (Martin et al., 2015). Breakpoint positions were evaluated using graphs constructed by the MaxChi, RDP and BootScan programs, and by viewing the positions identified by multiple programs on the relevant sequences. Locations of the parental and recombinant sequences within tree topologies drawn from areas on both sides of the breakpoint were compared to ensure the correct sequence was identified as the recombinant. To determine whether two recombinants were unique or originated from the same ancestral event, the recombination signals were compared using BootScan and RDP plots. To investigate the effect of recombination on phylogenetic tree topologies, whole genome recombinant sequences were not excluded from further analyses.

Phylogenetic trees were constructed from the three alignments (whole genome, CPreg and $p R E P$ ) in MEGA V7.0.18 (Kumar et al., 2016) using the Neighbour-Joining algorithm, with 1000 bootstrap replicates and the other parameters set at default as described in Glasa et al. (2017). Nodes with bootstrap support values lower than 50\% were collapsed and phylogenetic lineages were defined and named according to $\mathrm{Hu}$ et al. (2015).

Pairwise comparisons of whole genome, CPreg-trimmed and $p R E P$-trimmed sequences were performed using CLC Main Workbench V7.7.1 (CLC Bio-Qiagen, Aarhus, Denmark). Groups were defined according to the clustering of sequences in the phylogenetic tree corresponding to the area under investigation. For the CPreg amino acid pairwise comparison, non-coding areas were not included.

\section{6}

\section{Recombination analysis of survey samples}

Sequence data from the survey samples for the CPreg and $p R E P$ areas were aligned using the FFTNS-1 strategy in MAFFT V7 (Katoh and Standley, 2013) as previously described for the whole genome sequence alignment. The two alignments comprised the assembled sequences of all clones for that region and corresponding region of the reference sequences. Alignments were manually refined in Mesquite V3.2 (Maddison and Maddison, 2017) and screened for the presence of possible 
recombination events using RDP4 V8.20 (Martin et al., 2015). Window sizes were set at 10\% of the total number of variable sites for RDP, MaxChi and Chimaera, and 10\% of the total alignment length for BootScan and SiScan. A step size of 50\% of the window size was specified for BootScan and SiScan. The other parameters were left as specified for the whole genome recombination analysis. Manual refinement of preliminary results followed, using the program manual as guideline, as described above. All further analyses were conducted on a new alignment of each region, with all recombinant sequences removed, as exported by the program.

\subsection{Phylogenetic analysis}

The nucleotide substitution model best fit for the data was determined using jModelTest 2 on CIPRES (Darriba et al., 2012; Miller et al., 2010). The number of substitution schemes was set at 7, as it included all the relevant models to be tested. Models with unequal base frequencies and a proportion of invariable sites were included. A Maximum Likelihood tree was constructed and used as the base tree topology for likelihood calculations. The program was allowed to select the best tree topology search option between Nearest Neighbour Interchange (NNI) and Subtree Pruning and Regrafting (SPR). The Alkaike and Bayesian Information Criteria (AIC and BIC) were used to measure the quality of the statistical methods based on how well they fit the data compared to their complexity. The Corrected Alkaike Information Criterion was not used, as the number of parameters available were less than the recommended maximum of $30 \%$ of the number of sequences in the alignment. Phylogenetic trees were constructed for the CPreg and pREP areas in RAxML-HPC Black Box V9.2.10 (Stamatakis, 2014) on CIPRES (Miller et al., 2010) using the GTRCATI approximation model selected for both regions based on the AIC and BIC in jModelTest2, to optimise substitution rates and site-specific evolutionary rates. A threshold for bootstrapping was automatically set following the majority rule 'autoMRE' criterion. The best scoring Maximum Likelihood tree of each area was edited in Dendroscope V3.5.8 (Huson and Scornavacca, 2012) and nodes with a bootstrap value of less than 50\% were collapsed. Resulting condensed trees were visualised in Figtree V1.4.3 (Rambaut and Drummond, 2015). Pairwise comparisons within and between taxon groups were performed using CLC Main Workbench V7.7.1 (CLC Bio-Qiagen, Aarhus, Denmark).

For the CPreg amino acid pairwise comparison, non-coding areas were not included. Evolutionary distances, represented by the number of base differences per site averaging over all sequence pairs, between and within groups were calculated in MEGA7 (Kumar et al., 2016) using the p-distance model, assuming uniform rates and a homogenous pattern among lineages. Gaps and missing data were treated as complete deletions. CPreg and pREP areas were analysed separately. 


\section{Chapter 4: Results}

\subsection{Phylogenetic classification of reference sequences}

To identify reference sequences within each phylogenetic group for the CPreg and $p R E P$ areas, and to investigate the effect of recombination on phylogenetic trees constructed from different genomic regions, separate phylogenetic trees were constructed from the whole genome (Figure 11A), CPregtrimmed (Figure 11B) and $p R E P$-trimmed (Figure 11C) alignments containing the 18 whole genome sequences available on GenBank. Classification of three isolates, Tannat (KR528585.1), BS (AY881627.1) and SK30 (KX274277.1) were not consistent in all three phylogenetic networks and correlated with three recombination events detected within the whole genome reference sequences. These results were in accordance with recombination detected by Glasa et al. (2017). Parental lineages were inferred from the classification of the sequences identified by RDP4 V8.20 (Martin et al., 2015) as being representative of the minor and major parents of the recombinant. The results of these analyses are shown in Figure 12. Nucleotide percentage identities within and between phylogenetic groups for the whole genome, CPreg-trimmed and $p R E P$-trimmed are summarised in Table 4.

\subsection{Prevalence of GRSPaV in three respective surveys}

Total RNA was extracted from 59 accessions in the NV survey, and 117 plants in the OV survey. HMW RNA was extracted from all 176 plants in the MB survey. Total RNA concentrations ranged between 93.20 and $1388.20 \mathrm{ng} . \mu \mathrm{l}^{-1}$ with $\mathrm{A} 260 / 280$ ratios of $1.2-2.16$ and A260/230 ratios of 0.82 2.41, whereas the HMW extraction method delivered between 88.9 and $1782.6 \mathrm{ng} . \mu \mathrm{l}^{-1} \mathrm{HMW}$ RNA, with A260/280 and A260/230 ratios of $1.85-2.17$ and $1.71-2.48$, respectively. Approximately $71.19 \%, 29.06 \%$ and $6.25 \%$ of the samples from the NV, OV and MB surveys respectively, tested positive for GRSPaV. A minimum of three CPreg and three $p R E P$ clones from each sample were sequenced, with the exception of a single sample from the OV survey, from which the $p R E P$ region failed to amplify multiple times. In total, 264 CPreg and 258 pREP clones were sequenced. Clone names consist of four components: survey name (NV, OV or MB), genomic area (CPreg or $p R E P)$, sample number and clone identity. 

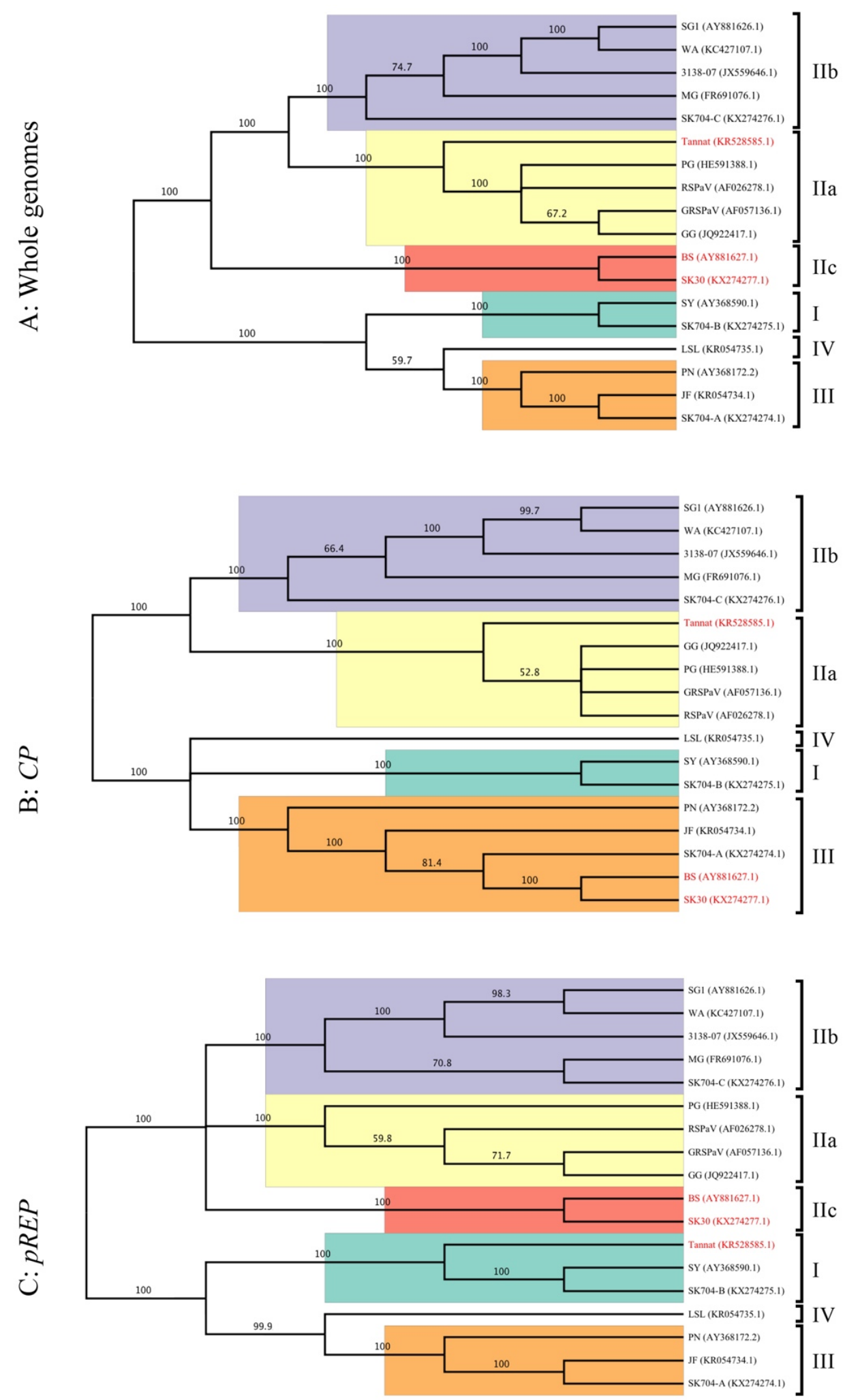

Figure 11 Phylogenetic trees constructed from $18 \mathrm{GRSPaV}$ genome reference sequences available on GenBank. Topology (A) is based on whole genome sequences, whereas alignments used to construct the other trees were trimmed to contain only the CPreg (B) and pREP (C) genome areas. Phylogenies were constructed in MEGA V7.0.18 (Kumar et al., 2016), using the Neighbour-Joining method with default parameters and 1000 bootstrap replicates, as described in Glasa et al. (2017). Nodes were collapsed using a bootstrap cut-off value of 50 and bootstrap values are displayed above nodes. Lineages of reference sequences are stated on the right of each figure. Recombinant sequences are indicated in red. 

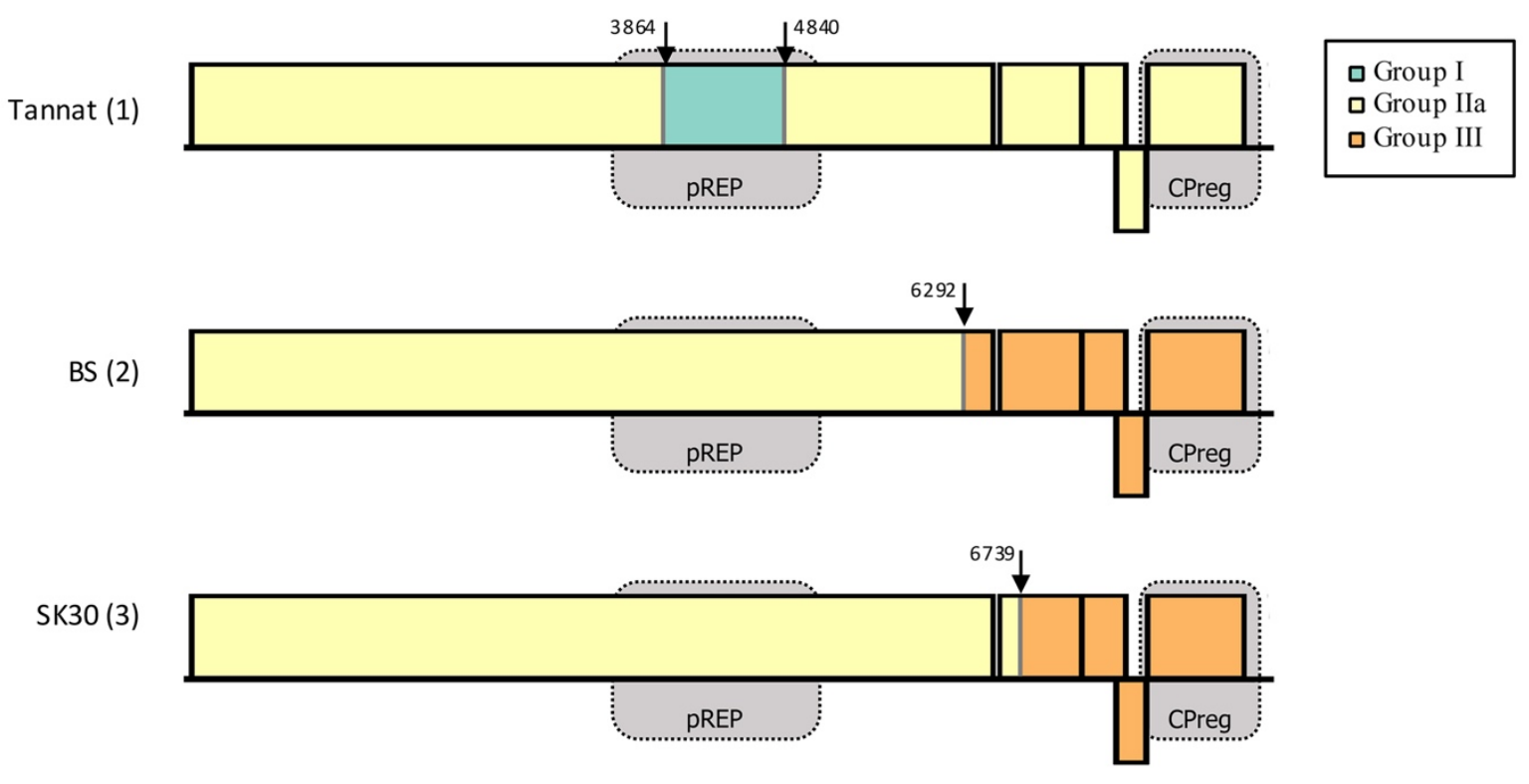

\begin{tabular}{llll}
\hline Event & Recombinant Isolate & Major parental lineage & Minor parental lineage \\
\hline \hline 1 & Tannat (KR528585.1) & IIa & I \\
2 & BS (AY881627.1) & IIa & III \\
3 & SK30 (KX274277.1) & IIa & III \\
\hline
\end{tabular}

Figure 12 Summary and schematic representation of refined recombination detection results of whole genome reference sequences obtained from RDP4 V8.20 (Martin et al., 2015). Event numbers are given in brackets next to each recombinant sequence. Breakpoint positions are indicated by the black arrows on the schematic representation of each recombinant genome. Parental lineages were inferred from the most likely parental sequence as indicated by the program, and the areas contributed by them are colored accordingly. Grey blocks indicate the positions of the $p R E P$ and CPreg genomic areas under investigation in this study.

\subsection{Phylogenetic analyses of survey samples}

Pairwise comparisons of all sequences revealed nucleotide identities of $79.85 \%-100 \%$ and amino acid identities of $90 \%-100 \%$ between CPreg sequences. Sequence identities for $p R E P$ ranged between $76.92 \%-100 \%$ on a nucleotide level and $90.63 \%-100 \%$ on an amino acid level.

Recombination results of survey samples and corresponding areas of reference sequences included in these alignments, are presented in Figure 13. Minor and major parental lineages were extrapolated from the classification of the relevant sequences during phylogenetic analysis. Where the most likely parent was unknown, the second most likely parent was selected to represent the parental lineage. Lineages IIa and IV did not partake in any recombination events within the CPreg region, whereas only groups I and subgroups of II were involved in recombination events within the $p R E P$ region. 


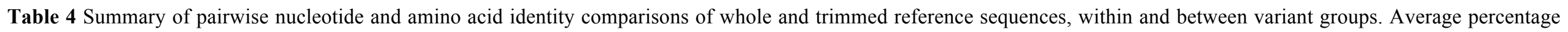

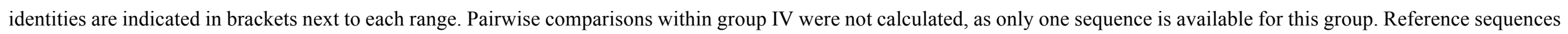
for group IIc were classified as group III in the CPreg comparisons. All analyses were conducted in CLC Main Workbench V7.7.1 (CLC Bio-Qiagen, Aarhus, Denmark).

\begin{tabular}{|c|c|c|c|c|c|}
\hline & Whole genomes: nucleotide & CPreg: nucleotide & CPreg: amino acid & pRep: nucleotide & pRep: amino acid \\
\hline \multicolumn{6}{|c|}{ Within groups } \\
\hline I & $93.81-93.81(93.81)$ & $95.91-95.91(95.91)$ & $98.85-98.85(98.85)$ & $89.51-95.32(91.53)$ & $97.30-99.28(98.08)$ \\
\hline IIa & $92.20-98.34(95.76)$ & $95.26-99.14(97.45)$ & $98.08-99.62(98.77)$ & $97.90-98.50(98.24)$ & $98.56-99.46(99.10)$ \\
\hline $\mathrm{IIb}$ & $92.93-99.54(95.11)$ & 95.15 - $99.68(96.80)$ & $96.54-99.62(97.85)$ & $93.59-99.82(95.59)$ & $97.30-99.64(98.15)$ \\
\hline IIc & 96.99 - $96.99(96.99)$ & n.a. & n.a. & $97.72-97.72(97.72)$ & $99.46-99.46(99.46)$ \\
\hline III & $83.04-90.01(85.48)$ & $88.04-98.06(92.23)$ & $95.38-99.23(97.5)$ & $84.35-90.17(86.75)$ & $93.87-97.66(95.56)$ \\
\hline \multicolumn{6}{|c|}{$\underline{\text { Between groups }}$} \\
\hline I and IIa & $76.74-77.64(77.18)$ & $80.93-83.84(82.73)$ & $92.69-94.23(93.46)$ & $79.20-86.57(82.04)$ & $94.05-95.86(94.80)$ \\
\hline I and IIb & $76.94-77.52(77.19)$ & $82.76-84.16(83.45)$ & $91.15-93.46(92.54)$ & $79.92-83.33(81.31)$ & $94.05-95.14(94.44)$ \\
\hline I and IIc & $77.23-77.47(77.33)$ & n.a. & n.a. & $79.26-83.03(80.73)$ & $93.51-94.41(93.90)$ \\
\hline I and III & $76.63-76.85(76.74)$ & $82.44-83.41(82.78)$ & $92.69-94.23(93.54)$ & $78.66-80.82(79.77)$ & $91.71-94.41(93.27)$ \\
\hline I and IV & $76.72-76.75(76.74)$ & $83.62-83.84(83.73)$ & $95.00-95.77(95.39)$ & $77.22-78.00(77.48)$ & $92.79-92.79(92.79)$ \\
\hline IIa and IIb & $84.58-87.68(87.07)$ & $87.50-91.59(90.13)$ & $95.38-98.85(97.08)$ & $87.77-89.15(88.50)$ & $96.58-97.66(97.08)$ \\
\hline IIa and IIc & $81.62-84.96(83.96)$ & n.a. & n.a. & $87.83-88.61(88.36)$ & $96.94-97.66(97.44)$ \\
\hline IIa and III & $74.72-77.18(76.20)$ & $78.77-82.11(81.03)$ & $92.31-94.23(93.31)$ & $78.60-79.44(79.24)$ & $92.61-94.59(93.57)$ \\
\hline IIa and IV & $75.21-77.02(76.59)$ & $79.53-82.54(81.81)$ & $95.38-96.92(96.07)$ & $78.54-78.90(78.68)$ & $92.61-92.97(92.79)$ \\
\hline IIb and IIc & $83.83-84.75(84.28)$ & n.a. & n.a. & $87.11-88.49(87.65)$ & $96.58-97.30(96.85)$ \\
\hline IIb and III & $75.57-76.69(76.11)$ & $80.06-82.22(81.27)$ & $90.38-93.85(92.22)$ & $78.42-79.56(78.86)$ & 91.89 - $93.69(92.99)$ \\
\hline IIb and IV & 76.57 - $76.84(76.74)$ & $82.65-83.30(83.02)$ & $93.85-96.15(95.15)$ & $78.18-78.78(78.54)$ & $92.25-93.51(92.97)$ \\
\hline IIc and III & $77.66-80.80(79.27)$ & n.a. & n.a. & $78.42-80.22(79.22)$ & $92.97-93.33(93.12)$ \\
\hline IIc and IV & $76.99-77.04(77.02)$ & n.a. & n.a. & $79.38-79.38(79.38)$ & $92.79-92.97(92.88)$ \\
\hline III and IV & 76.29 - $76.93(76.59)$ & $81.47-82.97(82.61)$ & $95.38-96.15(95.77)$ & $78.42-79.20(78.90)$ & $91.89-92.79(92.31)$ \\
\hline
\end{tabular}




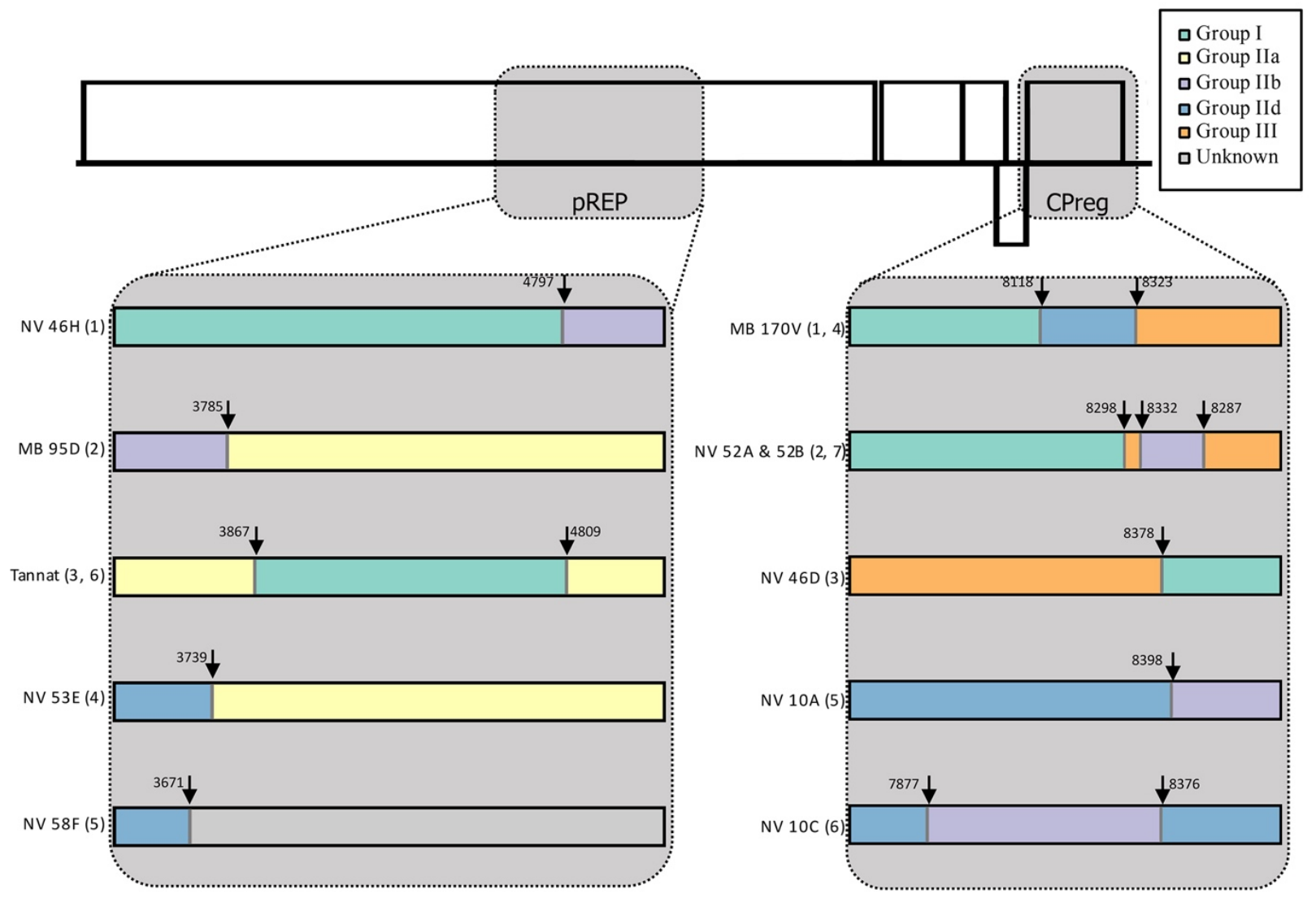

\begin{tabular}{llll}
$\boldsymbol{p R E P}$ & & & \\
\hline Event & Recombinant isolate & Major parental lineage & Minor parental lineage \\
\hline \hline 1 & NV pREP 46H & I & IIb \\
2 & MB pREP 95D & IIa & IIb \\
3 & Tannat(KR528585.1) & I & IIa \\
4 & NV pREP 53E & IIa & IId \\
5 & NV pREP 58F & Unknown & IId \\
6 & Tannat(KR528585.1) & I & IIa \\
\hline \hline
\end{tabular}

\begin{tabular}{llll} 
CPreg & & & \\
\hline Event & Recombinant isolate & Major parental lineage & Minor parental lineage \\
\hline \hline 1 & MB CPreg 170V & IId & I \\
2 & NV CPreg 52A & I & III x I \\
& NV CPreg 52B & & \\
3 & NV CPreg 46D & III & I \\
4 & MB CPreg 170V & III & IId \\
5 & NV CPreg 10A & IId & IIb x IId \\
6 & NV CPreg 10C & IIb & IId \\
7 & NV CPreg 52A & III & IIb \\
& NV CPreg 52B & & \\
\hline \hline
\end{tabular}

Figure 13 Tabular and schematic summary of recombination events detected within the CPreg and $p R E P$ areas of survey samples or reference sequences using RDP4 V8.20 (Martin et al., 2015). Event numbers are given in brackets next to each schematic representation of a recombinant genome areas, and breakpoint positions are indicated with arrows. Parental lineages were inferred from subsequent lineage classification of parental sequences, and areas contributed by parental sequences are colored accordingly. 
Phylogenetic trees were constructed from alignments containing survey and reference sequences of the two respective regions (Figure 14). Reference sequences clustered together in the same groups as previously described (Figure 11), and could therefore be used to identify lineage groups of isolates from this study. Between the two trees, all previously defined groups were distinguishable. Furthermore, a distinct subgroup of lineage II, not represented by any of the reference sequences used, was observed, and was labelled subgroup IId. The classification of variants based on either the CPreg or $p R E P$ clone sequences within the respective surveys, was compared (Figure 15).

To investigate whether multiple variants were present in individual plants or accessions, the sum of samples within each survey that contained one, two, three or four unique variants, as indicated by the two regions, was considered. Mixed infections were detected in samples originating from all three surveys, but was most common amongst the NV accessions.

Pairwise comparisons of survey samples within and between groups are summarised in Table 5 . Nucleotide identity ranges between currently recognised variant groups were compared to those of the proposed subgroup IId. The nucleotide identity within currently recognised lineages falls between $87.5 \%$ and $100 \%$ for the CPreg, and $83.63 \%$ and $100 \%$ for the $p R E P$ regions. Pairwise nucleotide identities within the new subgroup IId were $89.87 \%$ - 100\% and $90.53 \%-100 \%$ between CPreg and pREP sequences, respectively. Furthermore, a nucleotide identity of $79.85 \%-92.13 \%$ in the CPreg, and $76.93 \%-89.57 \%$ in the $p R E P$ region, was observed between previously classified lineages. The minimum and maximum percentage of nucleotides shared between subgroup IId and any of the previously classified lineages, were $80.6 \%$ and $92.67 \%$ for the CPreg, and $76.74 \%$ and $90.05 \%$ for the $p R E P$ regions.

The mean genetic distances between groups were 0.085 - 0.186 in the CPreg and $0.112-0.224$ in the $p R E P$ areas. These distances ranged from 0.024 to 0.062 within groups based on sequences of their coat protein, and 0.016 to 0.098 within groups based on $p R E P$ sequences. 
A

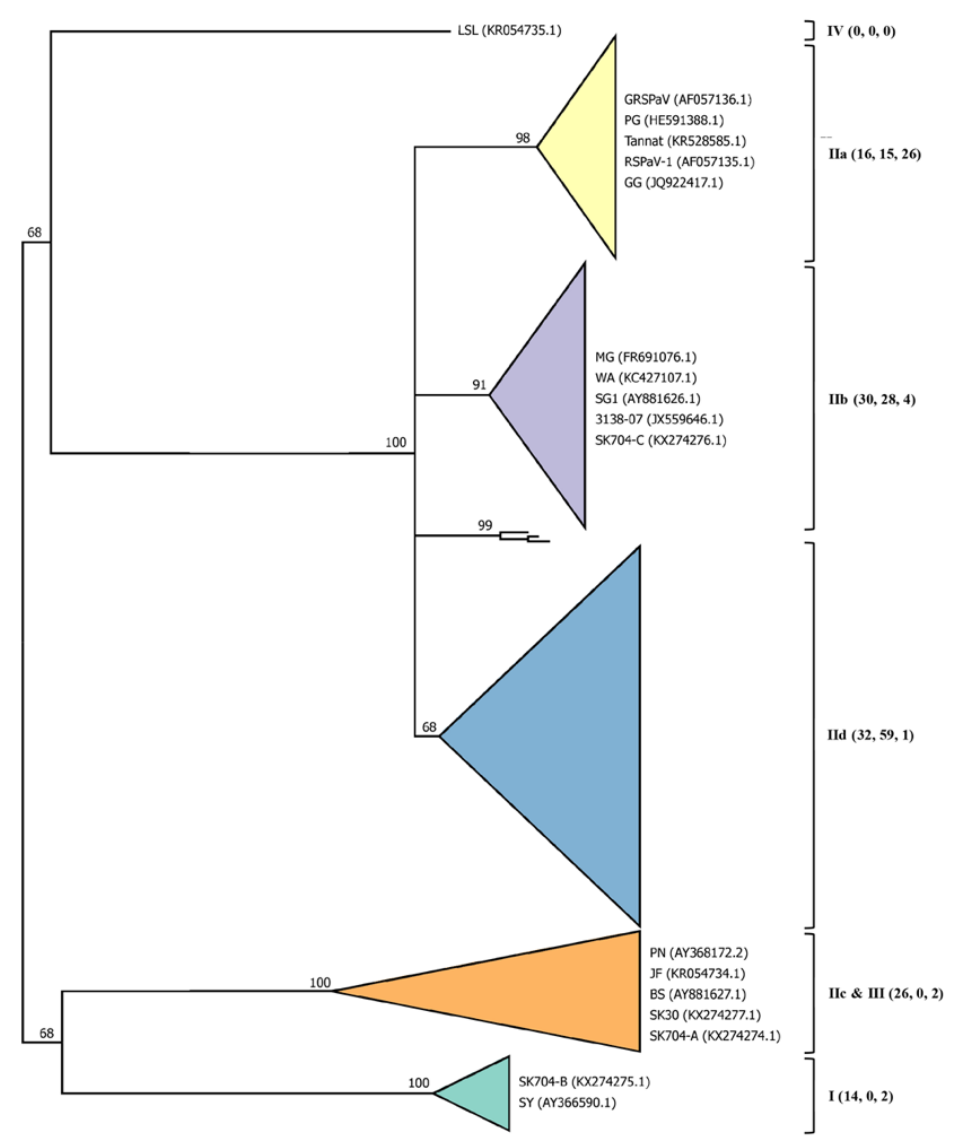

B



Figure 14 Phylogenetic analysis of GRSPaV diversity based on pREP (A) and CPreg (B) alignments with recombinant sequences removed. The best scoring Maximum Likelihood trees were generated by the Maximum Likelihood method using RAxML-HPC Black Box V8.2.10 on CiPRES and visualised and cartooned using Figtree V1.4.3 (Rambaut and Drummond, 2015). Bootstrap values are indicated at branch nodes. Nodes with bootstrap support values of less than 50 were collapsed. The height of each clade is an indication of the number of sequences therein, whereas clade depth indicates diversity. Reference sequences of respective lineages within each group are indicated next to clusters, and lineage names are given at the right of each topology followed by the number of clones within the (NV, OV and MB) surveys that clustered within specific groups. 


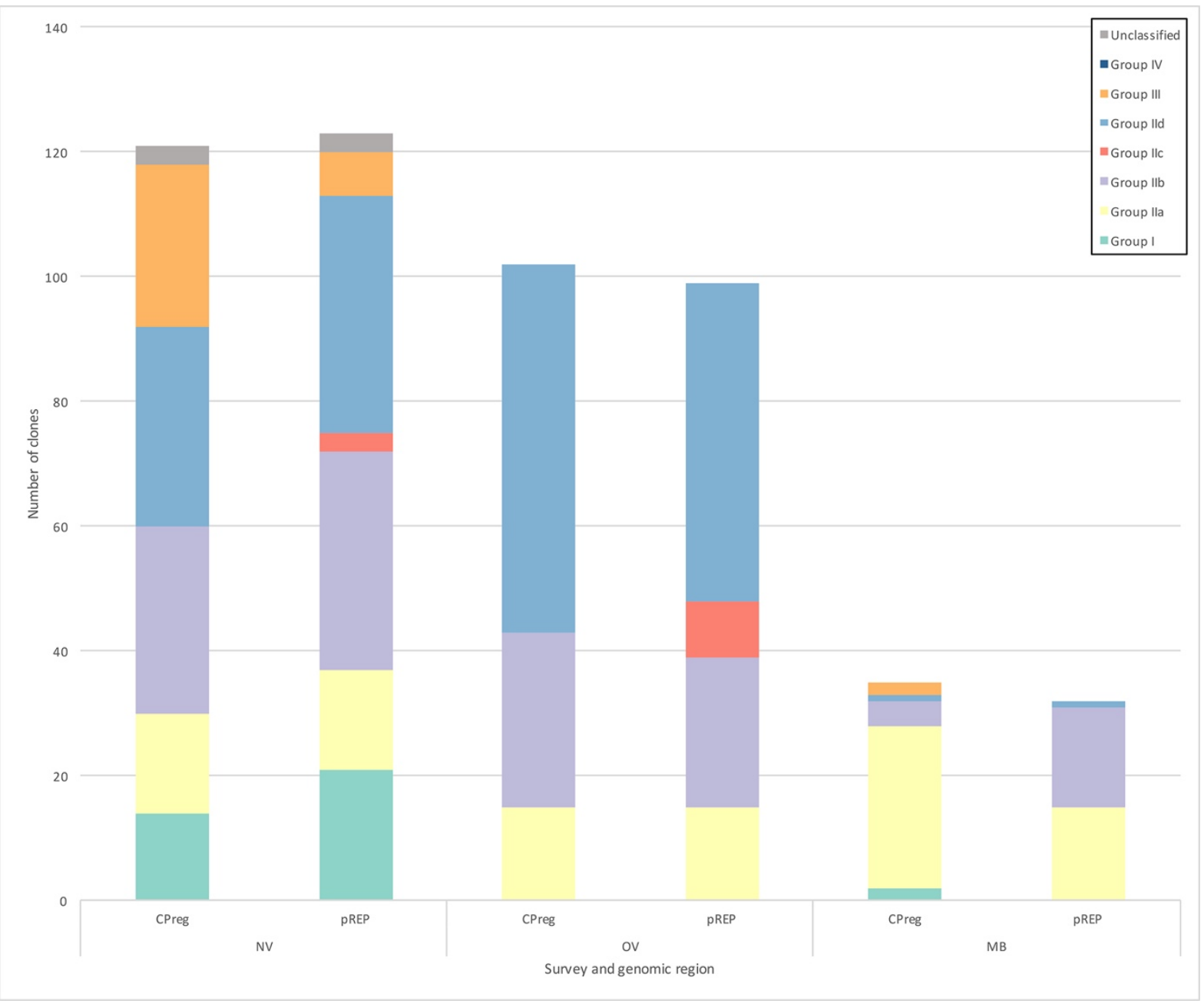

Figure 15 Comparison of lineage classification of clones based on the CPreg and $p R E P$ areas within each survey. Recombinant sequences were excluded as they did not belong to a single specific lineage. No group IIc could be discerned within tree topologies based on CPreg sequences. 


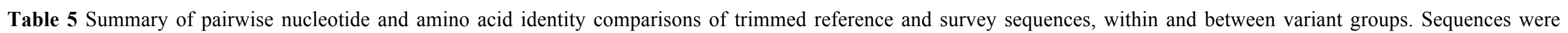



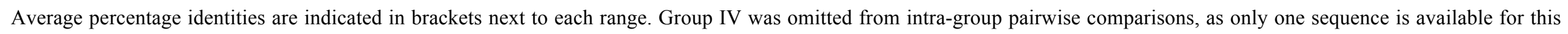
group. All analyses were conducted in CLC Main Workbench V7.7.1 (CLC Bio-Qiagen, Aarhus, Denmark).

\begin{tabular}{|c|c|c|c|c|}
\hline & CPreg: nucleotide & CPreg: amino acid & pRep: nucleotide & pRep: amino acid \\
\hline \multicolumn{5}{|c|}{ Within groups } \\
\hline$\overline{\mathrm{I}}$ & $95.47-100.00(96.93)$ & $98.46-100.00(99.26)$ & $93.53-99.76(95.37)$ & $97.66-100.00(98.96)$ \\
\hline IIa & $95.04-100.00(97.68)$ & $96.54-100.00(99.08)$ & $93.71-100.00(96.77)$ & $95.86-100.00(98.38)$ \\
\hline $\mathrm{IIb}$ & $94.40-100.00(96.88)$ & $95.38-100.00(98.93)$ & $92.69-100.00(95.25)$ & $96.40-100.00(98.39)$ \\
\hline IIc & n.a. & n.a. & $97.30-99.94(98.41)$ & $98.74-100.00(99.32)$ \\
\hline IId & $89.87-100.00(95.28)$ & $97.69-100.00(99.04)$ & $90.53-100.00(94.26)$ & $95.14-100.00(98.15)$ \\
\hline III & $87.50-100.00(93.90)$ & $95.38-100.00(98.48)$ & $83.63-99.46(90.19)$ & $93.33-99.64(96.83)$ \\
\hline \multicolumn{5}{|c|}{ Between groups } \\
\hline I and IIa & $81.36-83.84(82.52)$ & $91.54-94.23(93.22)$ & $79.02-81.41(80.31)$ & $91.89-94.95(93.70)$ \\
\hline $\mathrm{I}$ and IIb & $82.11-84.81(83.39)$ & $90.38-94.62(93.52)$ & $78.54-81.71(80.43)$ & $92.43-95.32(94.17)$ \\
\hline I and IIc & n.a. & n.a. & $78.84-80.58(79.85)$ & $92.97-94.23(93.61)$ \\
\hline I and IId & $81.25-83.94(82.80)$ & $91.92-94.62(93.42)$ & $78.24-81.47(79.95)$ & $91.35-94.77(93.61)$ \\
\hline I and III & $81.47-84.59(83.05)$ & $92.69-95.00(93.97)$ & $78.30-80.94(79.97)$ & $91.89-94.59(93.56)$ \\
\hline I and IV & $82.65-83.84(83.29)$ & $95.00-95.77(95.49)$ & $76.92-78.24(77.52)$ & 91.89 - $92.97(92.59)$ \\
\hline IIa and IIb & $88.79-92.13(90.52)$ & $94.62-99.23(97.55)$ & $86.75-89.57(88.48)$ & $94.59-98.56(97.17)$ \\
\hline IIa and IIc & n.a. & n.a. & $86.51-89.33(88.09)$ & $95.50-98.38(97.20)$ \\
\hline IIa and IId & $88.36-92.13(90.55)$ & $95.38-98.85(97.00)$ & $85.91-90.05(88.50)$ & $93.87-98.38(96.98)$ \\
\hline IIa and III & $79.85-82.87(81.27)$ & $91.15-95.00(93.16)$ & $78.18-80.10(79.20)$ & $91.35-94.59(92.90)$ \\
\hline IIa and IV & $81.25-82.97(82.23)$ & $94.62-96.92(95.64)$ & $78.00-78.90(78.45)$ & $90.99-92.97(92.21)$ \\
\hline IIb and IIc & n.a. & n.a. & $86.39-88.91(87.76)$ & $95.50-98.20(97.13)$ \\
\hline IIb and IId & $89.12-92.67(91.24)$ & $95.00-99.62(97.94)$ & $85.73-89.63(87.76)$ & $93.51-97.84(96.27)$ \\
\hline IIb and III & $79.96-83.08(81.84)$ & $90.00-95.00(93.40)$ & $77.64-80.04(78.87)$ & $91.35-94.41(93.22)$ \\
\hline IIb and IV & $82.54-83.94(83.26)$ & $93.85-96.92(95.98)$ & $77.70-78.90(78.31)$ & $92.07-93.69(92.88)$ \\
\hline IIc and IId & n.a. & n.a. & $85.97-89.39(88.01)$ & $93.87-97.30(96.14)$ \\
\hline IIc and III & n.a. & n.a. & $78.30-80.22(79.25)$ & $92.25-93.69(92.85)$ \\
\hline IIc and IV & n.a. & n.a. & $79.14-79.56(79.34)$ & $92.61-93.51(93.03)$ \\
\hline IId and III & $80.60-83.19(81.83)$ & $91.54-95.00(93.33)$ & $77.94-80.70(79.49)$ & $90.63-94.05$ (92.69) \\
\hline IId and IV & $81.90-83.41(82.82)$ & $94.62-96.15(95.49)$ & $76.74-78.90(77.83)$ & 90.99 - $92.97(92.21)$ \\
\hline III and IV & $81.47-83.94(82.94)$ & $95.38-97.31(96.21)$ & $77.70-79.20(78.42)$ & $91.71-92.79(92.23)$ \\
\hline
\end{tabular}


Phylogenetic trees constructed from different genes are often not identical due to several factors such as the stochastic nature of mutation, variable mutation rates between genes, lineage sorting and recombination (Huerta-Cepas et al., 2007; Penny et al., 1982). Here, the influence of recombination on lineage classification is illustrated by the discrepancies between trees constructed from alignments of trimmed and whole genome sequences correlating to recombination results. A positional change of recombinant sequences between trees constructed from the portions of the alignment corresponding to sequence areas contributed by different parental sequences, is observed (Figures 11 and 12).

Within the whole genome-based tree (Figure 11A), isolates clustered into four major phylogenetic lineages (groups I, II, III and IV) with group II being further divided into subgroups IIa, IIb, and IIc. The most noticeable difference between phylogenetic trees generated from the trimmed regions is the absence of subgroup IIc within the CPreg-based topology (Figure 11B). The only isolates comprising this group, SK30 (KX274277.1) and BS (AY881627.1), clustered with the reference sequences of group III. Recombination events detected in both of these sequences occurred between the $p R E P$ and CPreg regions, separating them into two components, each represented by either a major or minor inferred parental sequence (Figure 12). Within the $p R E P$ area, these two sequences were most similar to group II, and clustered within their own subgroup IIc. However, the CPreg region falls downstream of the breakpoint position identified by the program, and is therefore more similar to group III, the lineage of the minor parent. Although it is tempting to deduce that subgroup IIc is not a discrete variant group, but instead is merely made up of recombinant sequences of groups IIa and III, the SK30 and BS isolates formed a separate cluster in both the whole genome and $p R E P$ trees. Consequently, it was decided that SK30 and BS, together with the other members of group III, will be references of group III for the CPreg region, but also serve as representative sequences for group IIc in the $p R E P$-based trees. Isolate Tannat (KR528585.1) clustered within subgroup IIa based on its whole genome and CPreg sequences, but transferred to group I in the $p R E P$-based tree. This is the result of a recombination event between groups IIa and I, with the CPreg and pREP genome areas separated by the breakpoint position, each falling within a region contributed by a parental sequence belonging to these respective lineages. This illustrates the increased influence of recombination on lineage classification in phylogenetic trees constructed from smaller areas due to a lower resolution. 
These findings may explain the inconsistencies observed between phylogenetic trees previously generated from coat protein ORF sequences and partial sequences of the RdRP region of the replicase polyprotein (Figures 7 and 8, Meng and Rowhani, 2017). For the purpose of readability, isolates will be referred to by their abbreviation (Table 2, column 3) and lineage names according to Meng and Rowhani (2017) will be preceded by "GRSPaV", as indicated before (Table 2, columns 6 and 7). In the phylogeny based on coat protein ORF sequences (Figure 8), isolates JF, VF1 and BS cluster together and are classified as members of variant group GRSPaV-BS. Isolate PN is also located within this cluster, but was excluded from this group by the authors. In the phylogeny based on partial RdRP sequences (Figure 7), isolates JF, VF1 and PN are located outside of group GRSPaV-BS, and are situated within the same broader cluster. Each of the isolates in this cluster are then separated into their own distinctive lineage: GRSPaV-JF, GRSPaV-ML (containing VF1) and GRSPaV-PN. In the same tree, variant group GRSPaV-BS is situated closer to groups GRSPaV-1 and GRSPaV-SG1.

Recombinant sequences are known to appear to move from one cluster to another in phylogenetic trees constructed from regions corresponding to the areas contributed by parental sequences (Martin et al., 2015). Because of the movement of isolate JF from group GRSPaV-BS in the coat protein ORF-based phylogeny (Figure 8), to group GRSPaV-JF in the partial RdRP-based tree (Figure 7), it was initially speculated that this isolate is either a naturally occurring chimeric virus, or an artefact generated by genome assembly using sequence reads originating from a sample co-infected with two distinct variants (Meng and Rowhani, 2017). In this study, however, we have confirmed that isolate BS is a recombinant. The behaviour of isolate BS within the two trees is also more consistent with that of a recombinant, as the clustering of other members inside the group (isolates JF, VF1 and PN) are more stable (Figures 7 and 8), whereas isolate BS moves outside of the group in the RdRP-based tree (Figure 7).

Here, we propose the fusion of groups GRSPaV-JF, GRSPaV-ML and GRSPaV-PN into group III (Figure 7, left; Figure 11), using isolates VF1, JF, and PN reference sequences. Members of group IIc with isolate BS as reference (Figure 7, left; Figures 11A and 11C), will be considered as an independent subgroup of II based their whole genomes and sequences from the replicase region. However, isolates from group IIc do not possess a coat protein diverse enough to be classified as an independent group, and will cluster within group III based in phylogenies based on sequences from their coat protein ORF (Figure 8, left; Figure 11B). In addition to providing consistency, this grouping will clarify classification of isolates JF, VF1 and PN, and resolve confusion caused by the inconsistent clustering of designated reference sequences between topologies generated by different genome areas. 
The inconsistent placement of recombinant sequences within phylogenetic trees may influence the stability of topologies and affect positions (and therefore classification) of other, non-recombinant sequences. For the purpose of this survey, it was decided that the best approach to consistent phylogenetic analyses of datasets containing evidence of recombination will be the removal of recombinant sequences from subsequent analyses. However, for larger datasets containing many recombinants, this will be a tedious and time-consuming process potentially leading to the loss of valuable data, and an alternative approach to best address such datasets remains to be developed (Martin et al., 2015).

The presence of GRSPaV in a large proportion of sampled accessions collected from various widespread grape cultivating regions reinforces the perception of the wide geographical distribution of the virus (Minafra et al., 2015). The prevalence of GRSPaV in the NV survey may be attributed to the diverse origins of source material, and the collection thereof prior to implementation of current sanitary measures. Although OV vineyards were also established prior to the implementation of current certification schemes, the decreased diversity of the sources of these vineyards compared to those of the NV survey could account for the lower incidence of GRSPaV observed. Furthermore, plants from the NV survey are maintained within the cultivar repository regardless of their sanitary status, whereas old vines had to remain economically viable throughout their existence. This indirect form of selection for healthy vines possibly contributed to a decrease of GRSPaV in older vineyards. As expected, a small percentage of MB samples tested positive for the presence of GRSPaV. All but one positive sample originated from the same block, which could indicate failed elimination of the virus from source material.

Nucleotide and amino acid identities of survey samples fell within the same ranges as those of reference sequences alone (Tables 4 and 5). The species demarcation criteria for the family Flexiviridae state that isolates sharing greater than $72 \%$ identity on a nucleotide or $80 \%$ identity on an amino acid level between their coat protein or polymerase genes are considered one species (Adams et al., 2004). Pairwise comparisons confirm that, although there is a degree of sequence diversity, the nucleotide and amino acid identities of all sequences satisfy the demarcation criteria for GRSPaV. On a nucleotide level $p R E P$ sequences proved to be more diverse, however, CPreg sequences had a slightly larger range of percentage sequence identities on an amino acid level. The helicase domain plays a critical role during replication of viral RNA, and is possibly involved in RNA unwinding and cap formation (Martelli et al., 2007). Consequently, the $p R E P$ region is less tolerant of non-synonymous mutations which can affect protein structure. In contrast, a change in coat protein structure could be less detrimental for GRSPaV, as the coat protein of non-vector borne viruses is 
under less purifying selection than those of vector-transmitted plant viruses (Chare and Holmes, 2004; Rubio et al., 2001).

The majority of isolates from the three surveys belonged to subgroups of lineage II, whereas no sequences clustered with group IV in either of the topologies generated for the two different fragments. In most cases, although no proof exists that fragments from the same sample originated from the same virus isolate and recombinant sequences were not taken into consideration, the classification of a collection of CPreg and $p R E P$ clones from a single sample, was consistent (Figure 14). The most striking discrepancy between the two topologies is the absence of subgroup IIc in the CPreg-based tree (Figure 14B). Consistent with topologies constructed previously, reference sequences of this group clustered with those of group III. Furthermore, isolates from the same survey samples of which the $p R E P$-sequences belonged to group IIc, clustered within group III based on the sequence of their coat protein. Pairwise comparisons of reference sequences (Table 4) indicate that group III is the most diverse on a nucleotide and amino acid level for all regions under investigation. The diversity is therefore not influenced by the inclusion of BS and SK30 in this group in the CPregbased phylogenies. The same observation can be made from pairwise comparisons between survey samples (Table 5).

Recombination of subgroup IIc and II between the CPreg and $p R E P$ regions detected in both BS and SK30 whole genome reference sequences were based on unique signals, therefore these recombinants are not descendants from the same ancestral event, but originated independently. Because group IIc pREP sequences originated from the same samples of which the CPreg sequences clustered with group III, there is a strong possibility that recombination in the region flanked by $p R E P$ and $C P r e g$ is more common. As a requirement for recombination to occur, two or more viruses need to be present in the same host (Simon-Loriere and Holmes, 2011). This may indicate that groups IIc and III occurred together more frequently, which would lead to a higher amount of recombination in the region between the two genome areas. Unfortunately, no separate group IIc sequences were detected within the CPreg region and, due to the uncoupling of CPreg and $p R E P$ sequences in this study, such events could not be investigated further, and therefore the origin of group IIc remains unclear. The most likely explanation is that members of group IIc possess a divergent replicase sequence, but are generally more similar to group III in the coat protein area.

A novel, previously undetected subgroup of lineage II, was distinguishable in both topologies and subsequently named IId (Figure 14). Subgroup IId contained CPreg sequences from isolates originating from the same samples as the $p R E P$ isolates belonging to this group. Observed nucleotide 
percentage identities within subgroup IId fall in the same range as those of the other subgroups, supporting the classification of these sequences as a new subgroup (Table 5). Although the majority of sequences were distributed between currently recognised variant groups and the single new subgroup IId, three coat protein and three partial replicase sequences remained unclassified within their respective trees, although it was evident that they belonged to variant group II. These sequences could be undetected recombinants, or belong to yet another previously undetected subgroup of this lineage.

With the exception of a single sample for a different block containing multiple GRSPaV variants, genetic diversity was lowest in the MB survey, where all samples belonged to group IIa or IIb. This further supports the hypothesis that the occurrence of GRSPaV is due to unsuccessful elimination in a single source material containing isolates from these groups. Additionally, groups IIa and IIb are known to elicit mild or no symptoms on indicator plants, providing some explanation for the existence of these variants in plants presumed to be virus-free. All GRSPaV isolates from the old vines belonged to lineage II based on their $p R E P$ sequences, with the coat protein sequences from samples containing group IIa clustering with group III. The slight increase in diversity compared to what was observed in the MB samples could be due to OV vines propagated from more heterogeneous source material. The high diversity of the global GRSPaV population has been confirmed by the segregation of NV survey isolates from various countries into all but one of the currently recognised, distinct lineages (Alabi et al., 2010; Lima et al., 2006a; Terlizzi et al., 2011).

Inter-plant genetic variation based on both CPreg and $p R E P$ sequences was also investigated. Mixed infections contribute to variable symptoms, causing difficulty in assessing correlation between symptoms expressed and sequence variance of viruses present. This can lead to misdiagnosis by biological indexing assays, and ultimately complicates extrapolation to the exact aetiological role of GRSPaV in RSP (Alabi et al., 2010; Nakaune et al., 2008). Furthermore, infection with multiple variants also provides conditions for recombination to occur, which has been associated with increased virulence, adaptability and the offset of deleterious mutations (Nagy, 2008; Simon-Loriere and Holmes, 2011). A considerably low occurrence of mixed infections was observed in the OV survey, where only one plant contained more than one sublineage of GRSPaV. The majority of mixed infections comprised no more than two variants, with the exception of one MB and two NV samples, in which three unique variants were detected. The slightly higher occurrence of mixed infections in the NV survey could be due to a higher diversity of source plants. Overall, a lack of multiple variant infections is likely the result of the small, generally clonal representation of each accession or plant in addition to the inability to introduce new variants without grafting, recombination or mutation. 
Based on these results, neither of the regions are more efficient at detecting multiple variants within one sample.

Inter-variant recombination, whether natural or PCR-mediated, is the combination of parental genomes of distinct origins into a chimeric molecule referred to as the recombinant. It requires the presence of two or more viral variants within the same plant or sample (Simon-Loriere and Holmes, 2011). Recombination was most common within the NV survey, where mixed infections were most common, and no recombination events were detected in samples originating from the old vines. The low incidence of recombination in the $\mathrm{OV}$ and $\mathrm{MB}$ surveys could be explained by the increased homogeneity of source material of these vineyards compared to those of the NV accessions.

Only a single recombination event was supported by more than one recombinant. For CPreg events 1, 2, 4 and 7, both parental lineages were present within the same accession or plant, based on classification of non-recombinant clones within that sample. Presence of parental sequences in the same samples as their associated recombinants may imply that the recombination event occurred within the sampled plant, or within the source from which it originated. Combined with the singular occurrence of each particular event, however, the presence of both parental lineages in the plant suggests that these recombination events are more likely PCR-mediated (Roratto et al., 2008; Smyth et al., 2010). To confirm that the recombination events did not occur in vitro, further experimentation will be required. Although it is not biologically impossible, reciprocal secondary recombination between sequences with a similar mosaic is relatively rare and difficult to describe, as entangled recombination signals complicate analyses (Martin et al., 2015). In the case of CPreg events 2 and 7, which took part within a single isolate, it is more plausible that the recombinant is a chimeric PCR artefact, as all detected lineages were present within the same sample and templates were therefore heterologous (Judo et al., 1998; Meyerhans et al., 1990; Odelberg et al., 1995). However, events 3 and 6 detected within the $p R E P$ region of Tannat (KR528585.1) corresponds to event 1 of the whole genome recombination analysis, and were probably separated as a result of a smaller sequence to the right of the end breakpoint on the trimmed fragment being more similar to a different parental sequence than that of its whole genome counterpart. Recombination events in clones for which both parental lineages were not detected within the same sample are more likely of a natural, in vivo origin. Nevertheless, the purpose of detecting recombinant sequences in this study were simply to remove them to minimise the influence of recombination on phylogenetic tree topologies.

The mean genetic distance, represented by the number of base differences per site averaging over all sequence pairs, is an estimate of average evolutionary divergence over pairs of sequences within or 
between groups. Genetic distances between groups indicate that groups IIb and III are the least related based on CPreg sequences, whereas groups I and IV share the least identity in the $p R E P$ region. Based on the mean genetic distance within groups, group IIa showed the least intra-group diversity in the CPreg region, and group III the most. In the $p R E P$ region, the genetic distance within group IIc was the lowest, and the highest was within group III.

In this study, the broad genetic diversity of GRSPaV was confirmed with the clustering of sequences obtained from two genomic regions within six currently recognised variant groups. Furthermore, a noticeable difference in the distribution of virus variants was observed between previously certified and uncertified plants. Uncertified plants contained a wider variety of variants, whereas blocks previously used for the production of propagation material primarily contained variants reported to be asymptomatic or only mildly symptomatic on indicator plants. This could be the result unsuccessful detection of GRSPaV in plants using visual tools like hardwood indexing, or failed elimination of the virus from source material. Incomplete elimination of GRSPaV from plants conforming to sanitary requirements indicates the need for development of improved detection and disease control methods, as non-symptom causing variants may still play a role in virus pathogenesis (Alabi et al., 2010). Sequence data generated in this study can assist in the development of a more sensitive diagnostic RT-PCR assay to detect all known GRSPaV lineages, and additional RT-PCR assays to detect specific variants.

A previously unclassified variant group of GRSPaV, IId, has been detected using both genomic regions. The classification of group IId as an independent subgroup is supported by the results of pairwise comparisons, with inter- and intra-group identity ranges similar to those of currently recognised lineages. Prospective studies may focus on generating a whole genome sequence of this new lineage using cDNA library preparation and RT-PCR, or next-generation sequencing. Furthermore, a small amount of sequences from both regions remained unclassified. It is possible that these sequences or isolates from group IId belong to GRSPaV-XX, another variant group proposed by Meng and Rowhani (2017). To investigate this, more comprehensive phylogenetic analyses using additional sequence data will be required.

Based on the analyses conducted in this study, the inconsistent classification of sequences from groups previously named GRSPaV-BS, GRSPaV-JF and GRSPaV-PN is due to the use of a recombinant sequence as a group representative. Members of group GRSPaV-BS (IIc) do not possess coat protein sequences diverse enough for classification as a separate group, and should therefore be classified as belonging to lineage III based on sequences from this region. However, sequences from 
the replicase area provides phylogenetic topologies with an increased resolution. Therefore, although both the coat protein and replicase-based genomic areas were successful in classification of most variants, discrepancies caused by the use of two genomic regions indicate that a combination of sequence data from both areas will provide the most comprehensive representation of sequence diversity.

Finally, the study provides evidence of the effect of recombination on the classification of variants in tree topologies, particularly where smaller genomic areas are concerned, and underlines the importance of considering such factors when attempting to characterise virus diversity. 


\section{References}

Adams, M.J., Accotto, G.P., Agranovsky, A.A., Bar-Jospeh, M., Boscia, D., Xanother, A., 2005. Family Flexiviridae, in: Fauquet, C.M., Mayo, M.A., Maniloff, J., Desselberger, U., Ball, L.A. (Eds.), Virus Taxonomy: Eighth Report of the International Committee on Taxonomy of Viruses. Elservier, Amsterdam.

Adams, M.J., Antoniw, J.F., 2006. DPVweb: a comprehensive database of plant and fungal virus genes and genomes. Nucleic Acids Res. 34, D382-D385. doi:10.1093/nar/gkj023

Adams, M.J., Antoniw, J.F., Bar-Joseph, M., Brunt, A.A., Candresse, T., Foster, G.D., Martelli, G.P., Milne, R.G., Zavriev, S.K., Fauquet, C.M., 2004. The new plant virus family Flexiviridae and assessment of molecular criteria for species demarcation. Arch. Virol. 149, 1045-1060. doi:10.1007/s00705-004-0304-0

Alabi, O.J., Casassa, L.F., Gutha, L.R., Larsen, R.C., Henick-Kling, T., Harbertson, J.F., Naidu, R.A., 2016. Impacts of Grapevine Leafroll Disease on Fruit Yield and Grape and Wine Chemistry in a Wine Grape (Vitis vinifera L.) Cultivar. PLOS ONE 11, e0149666. doi:10.1371/journal.pone.0149666

Alabi, O.J., Martin, R.R., Naidu, R.A., 2010. Sequence diversity, population genetics and potential recombination events in grapevine rupestris stem pitting-associated virus in Pacific North-West vineyards. J. Gen. Virol. 91, 265-276. doi:10.1099/vir.0.014423-0

Almeida, R., Daane, K., Bell, V., Blaisdell, G.K., Cooper, M., Herrbach, E., Pietersen, G., 2013. Ecology and management of grapevine leafroll disease. Front. Microbiol. 4. doi:10.3389/fmicb.2013.00094

Al Rwahnih, M., Daubert, S., Golino, D., Islas, C., Rowhani, A., 2015. Comparison of nextgeneration sequencing versus biological indexing for the optimal detection of viral pathogens in grapevine. Phytopathology 105, 758-763. doi:10.1094/PHYTO-06-14-0165-R 
Al Rwahnih, M., Daubert, S., Golino, D., Rowhani, A., 2009. Deep sequencing analysis of RNAs from a grapevine showing Syrah decline symptoms reveals a multiple virus infection that includes a novel virus. Virology 387, 395-401. doi:10.1016/j.virol.2009.02.028

Al Rwahnih, M., Osman, F., Sudarshana, M., Uyemoto, J., Minafra, A., Saldarelli, P., Martelli, G., Rowhani, A., 2012. Detection of Grapevine leafroll-associated virus 7 using real time qRTPCR and conventional RT-PCR. J. Virol. Methods 179, 383-389. doi:10.1016/j.jviromet.2011.11.026

Andret-Link, P., Laporte, C., Valat, L., Ritzenthaler, C., Demangeat, G., Vigne, E., Laval, V., Pfeiffer, P., Stussi-Garaud, C., Fuchs, M., 2004. Grapevine fanleaf virus: Still a major threat to the grapevine industry. J. Plant Pathol. 86, 183-195. doi:10.4454/jpp.v86i3.987

Atallah, S.S., Gómez, M.I., Fuchs, M.F., Martinson, T.E., 2012. Economic impact of Grapevine Leafroll Disease on Vitis vinifera cv. Cabernet franc in Finger Lakes Vineyards of New York. Am. J. Enol. Vitic. 63, 73-79. doi:10.5344/ajev.2011.11055

Barba, M., Ilardi, V., Pasquini, G., 2015. Control of pome and stone fruit virus diseases. Adv. Virus Res. 91, 47-83. doi:10.1016/bs.aivir.2014.11.001

Basso, M.F., Fajardo, T.V.M., Eiras, M., Ayub, R.A., Nickel, O., 2010. Production of polyclonal antiserum using recombinant coat protein of Rupestris stem pitting-associated virus. Ciênc. Rural 40, 2385-2388. doi:10.1590/S0103-84782010001100022

Basso, M.F., Fajardo, T.V.M., Pio-Ribeiro, G., Eiras, M., Zerbini, F.M., 2014. Advances and prospects in the study of viral and subviral diseases in grapevine with emphasis on the situation in Brazil. Revisão Anual de Patologia de Plantas 22, 160-207.

Basso, M.F., Fajardo, T.V.M., Saldarelli, P., Basso, M.F., Fajardo, T.V.M., Saldarelli, P., 2017. Grapevine virus diseases: Economic impact and current advances in viral prospection and management. Rev. Bras. Frutic. 39. doi:10.1590/0100-29452017411

Battany, M., Rowhani, A., Golino, D., 2004. Syrah in California: Decline or Disorder. Pract. Winery Vineyard 20-35. 
Beuve, M., Moury, B., Spilmont, A.-S., Sempé-Ignatovic, L., Hemmer, C., Lemaire, O., 2013. Viral sanitary status of declining grapevine Syrah clones and genetic diversity of Grapevine Rupestris stem pitting-associated virus. Eur. J. Plant Pathol. 135, 439-452. doi:10.1007/s10658-012$0101-7$

Beuve, M., Moury, B., Spilmont, A.-S., Sempé-Ignatovic, L., Hemmer, C., Lemaire, O., 2009. Viral sanitary status and genetic diversity of Rupestris stem pitting-associated virus in French Syrah clones exhibiting various susceptibility levels to decline., in: Extended Abstracts 16th Meeting of ICVG. Dijon, France, pp. 346-347.

Beuve, M., Sempé, L., Lemaire, O., 2007. A sensitive one-step real-time RT-PCR method for detecting Grapevine leafroll-associated virus 2 variants in grapevine. J. Virol. Methods 141, 117-124. doi:10.1016/j.jviromet.2006.11.042

Bianco, P.A., Zorloni, A., De Biasi, C., Belli, G., 2009. Preliminary investigations on a Syrah Decline in central Italy., in: Extended Abstracts 16th Meeting of ICVG. Dijon, France, pp. 348-349.

Bonfiglioli, R.G., Habili, N., Green, M., Schliefert, L.F., Symons, R.H., 1998. The hidden problem Rugose wood associated viruses in Australian viticulture. Aust. Grapegrow. Winemak. 420, 9-13.

Borgo, M., Bertazzon, N., Anaclerio, F., Angelini, E., 2009. Different variants of GRSPaV are associated to diverse diseases in grapevine, in: Extended Abstracts of the 16th Meeting of the International Council for the Study of Virus and Virus-like Diseases of the Grapevine. Dijon, France, pp. 327-328.

Bouyahia, H., Boscia, D., Savino, V., La Notte, P., Pirolo, C., Castellano, M.A., Minafra, A., Martelli, G.P., 2006a. The aetiological role of Grapevine rupestris stem pitting-associated virus in grapevine vein necrosis and Rupestris stem pitting diseases: State of the art and open questions., in: Extended Abstracts 15th Meeting of ICVG. Stellenbosch, South Africa, pp. 77-78.

Bouyahia, H., Boscia, D., Savino, V., La Notte, P., Pirolo, C., Castellano, M.A., Minafra, A., Martelli, G.P., 2005. Grapevine rupestris stem pitting-associated virus is linked with grapevine vein necrosis. VITIS - J. Grapevine Res. 44, 133. 
Bouyahia, H., Della Bartola, M., Materazzi, A., Triolo, E., 2009. Molecular characterisation of biologically divergent strains of GRSPaV., in: Extended Abstracts of the 16th Meeting of the International Council for the Study of Virus and Virus-like Diseases of the Grapevine. Dijon, France, pp. 329-330.

Bouyahia, H., Materazzi, A., Triolo, E., 2006b. Grapevine Vein Necrosis: Further data on etiology and diagnosis., in: 2006 First International Symposium on Environment Identities and Mediterranean Area. Corte-Ajaccio, pp. 629-636.

Bratlie, M.S., Drabløs, F., 2005. Bioinformatic mapping of AlkB homology domains in viruses. BMC Genomics 6, 1. doi:10.1186/1471-2164-6-1

Buck, K.W., 1996. Comparison of the replication of positive-stranded RNA viruses of plants and animals. Adv. Virus Res. 47, 159-251.

Bujarski, J.J., 2013. Genetic recombination in plant-infecting messenger-sense RNA viruses: overview and research perspectives. Front. Plant Sci. 4. doi:10.3389/fpls.2013.00068

Burger, J.T., Maree, H.J., 2015. Metagenomic next-generation sequencing of viruses infecting grapevines. Methods Mol. Biol. Clifton NJ 1302, 315-330. doi:10.1007/978-1-4939-26206_23

Buzkan, N., Notte, P.L., Karadag, S., Aktan, A., Saldarelli, P., Minafra, A., 2015. Detection of Grapevine rupestris stem pitting-associated virus in autochthonous grapevine cultivars in Turkey. J. Plant Pathol. 97, 387-389. doi:10.4454/JPP.V97I2.033

Carra, A., Gambino, G., Schubert, A., 2007. A cetyltrimethylammonium bromide-based method to extract low-molecular-weight RNA from polysaccharide-rich plant tissues. Anal. Biochem. 360, 318-320. doi:10.1016/j.ab.2006.09.022

Caruthers, J.M., McKay, D.B., 2002. Helicase structure and mechanism. Curr. Opin. Struct. Biol. 12, $123-133$.

Chare, E.R., Holmes, E.C., 2004. Selection pressures in the capsid genes of plant RNA viruses reflect mode of transmission. J. Gen. Virol. 85, 3149-3157. doi:10.1099/vir.0.80134-0 
Cohn, E., Tanne, E., Nitzany, F.E., 1970. Xiphinema italiae, a new vector of Grapevine fanleaf virus. Phytopathology 60, 181-182.

Conningarth Economists, 2015. Final Report - Macroeconomic Impact of the Wine Industry on the South African Economy (also with reference to the Impacts on the Western Cape) (No. 3). South African Wine Industry Information and Systems.

Constable, F., Rodoni, B., 2011. Grapevine fleck and associated viruses (Fact Sheet). The Grape and Wine Research and Development Corporation, Department of Primary Industries, Victoria, Australia.

Conti, M., Milne, R.G., Luisoni, E., Boccardo, G., 1980. A closterovirus from a stem-pitting diseased grapevine. Phytopathology 70, 394-399.

Darriba, D., Taboada, G.L., Doallo, R., Posada, D., 2012. jModelTest 2: more models, new heuristics and high-performance computing. Nat. Methods 9, 772. doi:10.1038/nmeth.2109

Demangeat, G., Komar, V., Van-Ghelder, C., Voisin, R., Lemaire, O., Esmenjaud, D., Fuchs, M., 2010. Transmission competency of single-female Xiphinema index lines for Grapevine fanleaf virus. Phytopathology 100, 384-389. doi:10.1094/PHYTO-100-4-0384

Digiaro, M., Elbeaino, T., Martelli, G.P., 2017. Grapevine fanleaf virus and Other Old World Nepoviruses, in: Meng, B., Martelli, G.P., Golino, D.A., Fuchs, M. (Eds.), Grapevine viruses: Molecular biology, diagnostics and management. Springer International Publishing, pp. 47-82.

Dzianott, A., Flasinski, S., Bujarski, J.J., 1995. Foreign complementary sequences facilitate genetic RNA recombination in brome mosaic virus. Virology 208, 370-375. doi:10.1006/viro.1995.1163

Engelbrecht, D.J., Nel, A.C., 1971. A graft-transmissible stem grooving of grapevines in the Western Cape Province (South Africa) resembling legno riccio (rugose wood). Pytophylactica 3, 93-96. 
Fajardo, T.V.M., Eiras, M., Nickel, O., Dubiela, C.R., Souto, E.R. de, 2012. Detection and partial molecular characterization of Grapevine fleck virus, Grapevine virus D, Grapevine leafrollassociated virus -5 and -6 infecting grapevines in Brazil. Ciênc. Rural 42, 2127-2130. doi:10.1590/S0103-84782012005000119

Galetto, R., Giacomoni, V., Véron, M., Negroni, M., 2006. Dissection of a Circumscribed Recombination Hot Spot in HIV-1 after a Single Infectious Cycle. J. Biol. Chem. 281, 27112720. doi:10.1074/jbc.M505457200

Gambino, G., Cuozzo, D., Fasoli, M., Pagliarani, C., Vitali, M., Boccacci, P., Pezzotti, M., Mannini, F., 2012. Co-evolution between Grapevine rupestris stem pitting-associated virus and Vitis vinifera $\mathrm{L}$. leads to decreased defence responses and increased transcription of genes related to photosynthesis. J. Exp. Bot. 63, 5919-5933. doi:10.1093/jxb/ers244

Giampetruzzi, A., Roumi, V., Roberto, R., Malossini, U., Yoshikawa, N., La Notte, P., Terlizzi, F., Credi, R., Saldarelli, P., 2012. A new grapevine virus discovered by deep sequencing of virusand viroid-derived small RNAs in Cv Pinot gris. Virus Res. 163, 262-268. doi:10.1016/j.virusres.2011.10.010

Glasa, M., Predajňa, L., Šoltys, K., Sihelská, N., Nagyová, A., Wetzel, T., Sabanadzovic, S., 2017a. Analysis of Grapevine rupestris stem pitting-associated virus in Slovakia reveals differences in intra-host population diversity and naturally occurring recombination events. Plant Pathol. J. 33, 34-42. doi:10.5423/PPJ.OA.07.2016.0158

Gmyl, A.P., Belousov, E.V., Maslova, S.V., Khitrina, E.V., Chetverin, A.B., Agol, V.I., 1999. Nonreplicative RNA Recombination in Poliovirus. J. Virol. 73, 8958-8965.

Goheen, A.C., 1989. Virus Diseases and Grapevine Selection. Am. J. Enol. Vitic. 40, 67-72.

Golino, D.A., 1993. Potential Interactions Between Rootstocks and Grapevine Latent Viruses. Am. J. Enol. Vitic. 44, 148-152.

Goszczynski, D.E., 2010. Rugose wood-associated viruses do not appear to be involved in Shiraz (Syrah) decline in South Africa. Arch. Virol. 155, 1463-1469. doi:10.1007/s00705-010-07140 
Graniti, A., Ciccarone, A., 1961. Osservazioni su alterazioni virosiche e virus-simili della vite in Puglia. Not. Sulle Mal. Delle Piante 55, 99-102.

Gribaudo, I., Gambino, G., Cuozzo, D., Mannini, F., 2006. Attempts to eliminate Grapevine rupestris stem pitting-associated virus from grapevine clones. J. Plant Pathol. 88, 293-298. doi:10.4454/jpp.v88i3.875

Gribaudo, I., Gambino, G., Vallania, R., 2004. Somatic Embryogenesis from Grapevine Anthers: The Optimal Developmental Stage for Collecting Explants. Am. J. Enol. Vitic. 55, 427-430.

Habili, N., Farrokhi, N., Lima, M. f., Nicholas, P., Randles, J. w., 2006. Distribution of Rupestris stem-pitting-associated virus variants in two Australian vineyards showing different symptoms. Ann. Appl. Biol. 148, 91-96. doi:10.1111/j.1744-7348.2006.00041.x

Habili, N., Krake, L.R., Barlass, M., Rezaian, M.A., 1992. Evaluation of biological indexing and dsRNA analysis in grapevine virus elimination. Ann. Appl. Biol. 121, 277-283. doi:10.1111/j.1744-7348.1992.tb03440.x

Hewitt, W.B., 1954. Some virus and virus-like diseases of grapevine. Bull. Calif. Dep. Agric. 43, 4764.

Hewitt, W.B., Neja, R., 1971. Grapevine bark and wood pitting disease found in California. Plant Dis. Report. 55, 860-861.

Hooker, J., 2017. Analysis of the genetic diversity of Grapevine rupestris stem pitting-associated virus in Ontarian vineyards and construction of a full-length infectious clone. (M.Sc. Thesis). University of Guelph.

Huerta-Cepas, J., Dopazo, H., Dopazo, J., Gabaldón, T., 2007. The human phylome. Genome Biol. 8, R109. doi:10.1186/gb-2007-8-6-r109

Hu, G.-J., Dong, Y.-F., Zhu, H.-J., Zhang, Z.-P., Fan, X.-D., Ren, F., Zhou, J., 2015. Molecular characterizations of two grapevine rupestris stem pitting-associated virus isolates from China. Arch. Virol. 160, 2641-2645. doi:10.1007/s00705-015-2544-6 
Huson, D.H., Scornavacca, C., 2012. Dendroscope 3: An Interactive Tool for Rooted Phylogenetic Trees and Networks. Syst. Biol. 61, 1061-1067. doi:10.1093/sysbio/sys062

Judo, M.S., Wedel, A.B., Wilson, C., 1998. Stimulation and suppression of PCR-mediated recombination. Nucleic Acids Res. 26, 1819-1825.

Kadaré, G., Haenni, A.L., 1997. Virus-encoded RNA helicases. J. Virol. 71, 2583-2590.

Kadaré, G., Rozanov, M., Haenni, A.-L., 1995. Expression of the turnip yellow mosaic virus proteinase in Escherichia coli and determination of the cleavage site within the $206 \mathrm{kDa}$ protein. J. Gen. Virol. 76, 2853-2857. doi:10.1099/0022-1317-76-11-2853

Katoh, K., Standley, D.M., 2013. MAFFT multiple sequence alignment software version 7: improvements in performance and usability. Mol. Biol. Evol. 30, 772-780. doi:10.1093/molbev/mst010

Koonin, E.V., 1991. The phylogeny of RNA-dependent RNA polymerases of positive-strand RNA viruses. J. Gen. Virol. 72 ( Pt 9), 2197-2206. doi:10.1099/0022-1317-72-9-2197

Koonin, E.V., Dolja, V.V., 1993. Evolution and taxonomy of positive-strand RNA viruses: implications of comparative analysis of amino acid sequences. Crit. Rev. Biochem. Mol. Biol. 28, 375-430. doi:10.3109/10409239309078440

Kumar, S., Stecher, G., Tamura, K., 2016. MEGA7: Molecular Evolutionary Genetics Analysis Version 7.0 for Bigger Datasets. Mol. Biol. Evol. 33, 1870-1874. doi:10.1093/molbev/msw054

Lahr, D.J.G., Katz, L.A., 2009. Reducing the impact of PCR-mediated recombination in molecular evolution and environmental studies using a new-generation high-fidelity DNA polymerase. BioTechniques 47, 857-866. doi:10.2144/000113219

Laliberté, J.-F., Sanfaçon, H., 2010. Cellular remodeling during plant virus infection. Annu. Rev. Phytopathol. 48, 69-91. doi:10.1146/annurev-phyto-073009-114239

LeMaguet, J., Beuve, M., Herrbach, E., Lemaire, O., 2012. Transmission of Six Ampeloviruses and Two Vitiviruses to Grapevine by Phenacoccus aceris. Phytopathology 102, 717-723. 
Lima, M., Alkowni, R., Uyemoto, J.K., Rowhani, A., 2009. Genomic study and detection of a new variant of Grapevine rupestris stem pitting associated virus in declining California Pinot Noir grapevines. J. Plant Pathol. 91, 155-162. doi:10.4454/jpp.v91i1.636

Lima, M.F., Alkowni, R., Uyemoto, J.K., Golino, D., Osman, F., Rowhani, A., 2006a. Molecular analysis of a California strain of Rupestris stem pitting-associated virus isolated from declining Syrah grapevines. Arch. Virol. 151, 1889-1894. doi:10.1007/s00705-006-0742-y

Lima, M.F., Rosa, C., Golino, D.A., Rowhani, A., 2006b. Detection of Rupestris stem pitting associated virus in seedlings of cirus-infected material grapevine plants., in: Extended Abstracts 15th Meeting of ICVG. South African Society for Enology and Viticulture, Stellenbosch, South Africa, pp. 244-245.

Li, Z., Martelli, G.P., Prota, U., 1989. A preliminary account of virus and virus-like disease of grapevines in the people's republic of China., in: Extended Abstracts 9th Meeting ICVG. Airyat-Anavim, Israel, pp. 57-78.

Lunden, S., Meng, B., Avery, J., Qiu, W., 2010. Association of Grapevine fanleaf virus, Tomato ringspot virus and Grapevine rupestris stem pitting-associated virus with a grapevine veinclearing complex on var. Chardonnay. Eur. J. Plant Pathol. 126, 135. doi:10.1007/s10658-0099527-y

Maddison, W.P., Maddison, D.R., 2017. Mesquite: a modular system for evolutionary analysis.

Makarova, K.S., Aravind, L., Koonin, E.V., 2000. A novel superfamily of predicted cysteine proteases from eukaryotes, viruses and Chlamydia pneumoniae. Trends Biochem. Sci. 25, 5052.

Maliogka, V.I., Martelli, G.P., Fuchs, M., Katis, N.I., 2015. Control of Viruses Infecting Grapevine Diseases: Vegetatively-Propagated Crops, in: Advances in Virus Research. Academic Press, Burlington, pp. 175-227. 
Maree, H.J., Almeida, R.P.P., Bester, R., Chooi, K.M., Cohen, D., Dolja, V.V., Fuchs, M.F., Golino, D.A., Jooste, A.E.C., Martelli, G.P., Naidu, R.A., Rowhani, A., Saldarelli, P., Burger, J.T., 2013. Grapevine leafroll-associated virus 3. Front. Microbiol. 4. doi:10.3389/fmicb.2013.00082

Martelli, G.P., 2017. An Overview on Grapevine Viruses, Viroids, and the Diseases They Cause, in: Meng, B., Martelli, G.P., Golino, D.A., Fuchs, M. (Eds.), Grapevine Viruses: Molecular Biology, Diagnostics and Management. Springer International Publishing, pp. 31-46.

Martelli, G.P., 2014. Directory of virus and virus-like diseases of the grapevine and their agents. J. Plant Pathol. 96, 1-136. doi:10.4454/JPP.V96I1SUP

Martelli, G.P., Abou Ghanem-Sabanadzovic, N., Agranovsky, A.A., Al Rwahnih, M., Dolja, V.V., Dovas, C.I., Fuchs, M., Gugerli, P., Hu, J.S., Jelkmann, W., Katis, N.I., Maliogka, V.I., Melzer, M.J., Menzel, W., Minafra, A., Rott, M.E., Rowhani, A., Sabanadzovic, S., Saldarelli, P., Martelli, G.P., Ghanem, N., Rwahnih, A.M., Dolja, V.V., Gugerli, P., Hu, J.S., Maliogka, V.I., Minafra, A., Rowhani, A., Saldarelli, P., 2012. Taxonomic revision of the family Closteroviridae with special reference to the Grapevine leafroll-associated members of the genus Ampelovirus and the putative species unassigned to the family.

Martelli, G.P., Adams, M.J., Kreuze, J.F., Dolja, V.V., 2007. Family Flexiviridae: a case study in virion and genome plasticity. Annu. Rev. Phytopathol. 45, 73-100. doi:10.1146/annurev.phyto.45.062806.094401

Martelli, G.P., Boudon-Padieu, E., 2006. Directory of infectious diseases of grapevines and viroses and virus-like diseases of the grapevine: bibliographic report 1998-2004. CIHEAM.

Martelli, G.P., De Sequeira, O.A., Kassemeyer, H.H., Padilla, V., Prota, U., Quecquarelli, A., Xanother, A., 1993. A scheme for grapevine certification in the Eurpean Economic Community. Br. Crop Prot. Counc. Monogr. 54, 279-284.

Martelli, G.P., Jelkmann, W., 1998. Foveavirus, a new plant virus genus. Arch. Virol. 143, 12451249. 
Martelli, G.P., Lehoczky, J., Quacquarelli, A., Sarospataki, G., 1967. A disorder resembling "legno riccio" (rugose wood) of grapevine in Hungary. Phytopathol. Mediterr. 6, 110-112.

Martelli, G.P., Savino, V., 1990. Fanleaf Degeneration, in: Pearson, R.C., Goheen, A. (Eds.), Compendium of Grape Diseases. APS Press, St Paul, MN, USA, pp. 48-49.

Martelli, G.P., Walter, B., Pinck, L., 2001. Descriptions of Plant Viruses: 385. Grapevine fanleaf virus. [WWW Document]. URL http://www.dpvweb.net/dpv/showdpv.php?dpvno=385 (accessed 9.16.17).

Martin, D.P., Murrell, B., Golden, M., Khoosal, A., Muhire, B., 2015. RDP4: Detection and analysis of recombination patterns in virus genomes. Virus Evol. 1. doi:10.1093/ve/vev003

Meng, B., Credi, R., Petrovic, N., Gonsalves, D., 2000. Serological detection of RSPaV in grapes as compared to RT-PCR and indicator indexing., in: Extended Abstracts 13th Meeting of ICVG. Adelaide, South Australia, pp. 131-132.

Meng, B., Credi, R., Petrovic, N., Tomazic, I., Gonsalves, D., 2003. Antiserum to Recombinant Virus Coat Protein Detects Rupestris stem pitting associated virus in Grapevines. Plant Dis. 87, 515522. doi:10.1094/PDIS.2003.87.5.515

Meng, B., Gonsalves, D., 2007. Grapevine rupestris stem pitting-associated virus: A Decade of Research and Future Perspectives. Plant Viruses 1, 52-62.

Meng, B., Gonsalves, D., 2003. Rupestris stem pitting-associated virus of grapevines: Genome structure, genetic diversity, detection, and phylogenetic relationship to other plant viruses. Research Trends. Curr. Top. Virol. 125-135.

Meng, B., Johnson, R., Peressini, S., Forsline, P.L., Gonsalves, D., 1999a. Rupestris Stem Pitting Associated Virus-1 is Consistently Detected in Grapevines that are Infected with Rupestris Stem Pitting. Eur. J. Plant Pathol. 105, 191-199. doi:10.1023/A:1008771713839

Meng, B., Li, C., 2010. The capsid protein of Grapevine rupestris stem pitting-associated virus contains a typical nuclear localization signal and targets to the nucleus. Virus Res. 153, 212217. doi:10.1016/j.virusres.2010.08.003 
Meng, B., Li, C., Wang, W., Goszczynski, D., Gonsalves, D., 2005. Complete genome sequences of two new variants of Grapevine rupestris stem pitting-associated virus and comparative analyses. J. Gen. Virol. 86, 1555-1560. doi:10.1099/vir.0.80815-0

Meng, B., Pang, S.Z., Forsline, P.L., McFerson, J.R., Gonsalves, D., 1998. Nucleotide sequence and genome structure of grapevine rupestris stem pitting associated virus-1 reveal similarities to apple stem pitting virus. J. Gen. Virol. 79 ( Pt 8), 2059-2069. doi:10.1099/0022-1317-79-82059

Meng, B., Rebelo, A.R., Fisher, H., 2006. Genetic diversity analyses of grapevine Rupestris stem pitting-associated virus reveal distinct population structures in scion versus rootstock varieties. J. Gen. Virol. 87, 1725-1733. doi:10.1099/vir.0.81533-0

Meng, B., Rowhani, A., 2017. Grapevine rupestris stem pitting-associated virus, in: Meng, B., Martelli, G.P., Golino, D.A., Fuchs, M. (Eds.), Grapevine Viruses: Molecular Biology, Diagnostics and Management. Springer International Publishing, pp. 257-287.

Meng, B., Venkataraman, S., Li, C., Wang, W., Dayan-Glick, C., Mawassi, M., 2013. Construction and biological activities of the first infectious cDNA clones of the genus Foveavirus. Virology 435, 453-462. doi:10.1016/j.virol.2012.09.045

Meng, B., Zhu, H.-Y., Gonsalves, D., 1999b. Rupestris stem pitting associated virus-1 consists of a family of sequence variants. Arch. Virol. 144, 2071-2085. doi:10.1007/s007050050623

Meyerhans, A., Vartanian, J.P., Wain-Hobson, S., 1990. DNA recombination during PCR. Nucleic Acids Res. 18, 1687-1691.

Miller, M.A., Pfeiffer, W., Schwartz, T., 2010. Creating the CIPRES Science Gateway for inference of large phylogenetic trees, in: 2010 Gateway Computing Environments Workshop (GCE). Presented at the 2010 Gateway Computing Environments Workshop (GCE), pp. 1-8. doi:10.1109/GCE.2010.5676129 
Minafra, A., Boscia, D., 2003. An overview of rugose wood-associated viruses: 2000 - 2003, in: The 14th Meeting of the International Council for the Study of Virus-like Diseases of the Grapevine. Presented at the The 14th Meeting of the International Council for the Study of Virus-like Diseases of the Grapevine, Locorotondo, Italy, pp. 116-119.

Minafra, A., Casati, P., Elicio, V., Rowhani, A., Saldarelli, P., Savino, V., Martelli, G.P., 2015. Serological detection of Grapevine rupestris stem pitting-associated virus (GRSPaV) by a polyclonal antiserum to recombinant virus coat protein. VITIS - J. Grapevine Res. 39, 115.

Minafra, A., Mawassi, M., Goszczynski, D., Saldarelli, P., 2017. Grapevine Vitiviruses, in: Meng, B., Martelli, G.P., Golino, D.A., Fuchs, M. (Eds.), Grapevine Viruses: Molecular Biology, Diagnostics and Management. Springer International Publishing, pp. 229-256.

Mine, A., Okuno, T., 2012. Composition of plant virus RNA replicase complexes. Curr. Opin. Virol., Virus replication in animals and plants 2, 669-675. doi:10.1016/j.coviro.2012.09.014

Morelli, M., Minafra, A., Boscia, D., Martelli, G.P., 2011. Complete nucleotide sequence of a new variant of grapevine rupestris stem pitting-associated virus from southern Italy. Arch. Virol. 156, 543-546. doi:10.1007/s00705-011-0936-9

Morozov, S.Y., Solovyev, A.G., 2003. Triple gene block: modular design of a multifunctional machine for plant virus movement. J. Gen. Virol. 84, 1351-1366. doi:10.1099/vir.0.18922-0

Nagy, P.D., 2008. Recombination in Plant RNA Viruses, in: Plant Virus Evolution. Springer, Berlin, Heidelberg, pp. 133-156.

Nagy, P.D., Bujarski, J.J., 1993. Targeting the site of RNA-RNA recombination in brome mosaic virus with antisense sequences. Proc. Natl. Acad. Sci. U. S. A. 90, 6390-6394.

Nagy, P.D., Pogany, J., 2008. Multiple roles of viral replication proteins in plant RNA virus replication. Methods Mol. Biol. Clifton NJ 451, 55-68. doi:10.1007/978-1-59745-102-4_4

Nagy, P.D., Pogany, J., Simon, A.E., 1999. RNA elements required for RNA recombination function as replication enhancers in vitro and in vivo in a plus-strand RNA virus. EMBO J. 18, 56535665. doi:10.1093/emboj/18.20.5653 
Naidu, R.A., Maree, H.J., Burger, J.T., 2015. Grapevine Leafroll Disease and Associated Viruses: A Unique Pathosystem. Annu. Rev. Phytopathol. 53, 613-634. doi:10.1146/annurev-phyto102313-045946

Naidu, R.A., Rowhani, A., Fuchs, M., Golino, D.A., Martelli, G.P., 2014. Grapevine Leafroll: A Complex Viral Disease Affecting a High-Value Fruit Crop. Plant Dis. doi:10.1094/PDIS-0813-0880-FE

Nakaune, R., Inoue, K., Nasu, H., Kakogawa, K., Nitta, H., Imada, J., Nakano, M., 2008. Detection of viruses associated with rugose wood in Japanese grapevines and analysis of genomic variability of Rupestris stem pitting-associated virus. J. Gen. Plant Pathol.

Nascimento, M.B., Fajardo, T.V.M., Eiras, M., Czermainski, A.B.C., Nickel, O., Pio-Ribeiro, G., 2015. Desempenho agronômico de videiras com e sem sintomas de viroses, e comparação molecular de isolados virais (Agronomic performance of grapevines with and without virus symptoms, and molecular comparison of viral isolates). Pesqui. Agropecuária Bras. 50, 541550. doi:10.1590/S0100-204X2015000700004

Nolasco, G., Mansinho, A., Santos, M.T., Soares, C., Sequeira, Z., Sequeira, C., Correia, P.K., Sequeira, O.A., 2000. Large Scale Evaluation of Primers for Diagnosis of Rupestris Stem Pitting Associated Virus-1. Eur. J. Plant Pathol. 106, 311-318. doi:10.1023/A:1008748924494

Nolasco, G., Santos, C., Petrovic, N., Teixeira Santos, M., Cortez, I., Fonseca, F., Boben, J., Nazaré Pereira, A.M., Sequeira, O., 2006. Rupestris stem pitting associated virus isolates are composed by mixtures of genomic variants which share a highly conserved coat protein. Arch. Virol. 151, 83-96. doi:10.1007/s00705-005-0611-0

Odelberg, S.J., Weiss, R.B., Hata, A., White, R., 1995. Template-switching during DNA synthesis by Thermus aquaticus DNA polymerase I. Nucleic Acids Res. 23, 2049-2057.

Panattoni, A., D’Anna, F., Triolo, E., 2006. Improvement in grapevine chemotherapy., in: Extended Abstracts 15th Meeting of ICVG. Stellenbosch, South Africa, pp. 139-141. 
Penny, D., Foulds, L.R., Hendy, M.D., 1982. Testing the theory of evolution by comparing phylogenetic trees constructed from five different protein sequences. Nature 297, 197-200. doi:10.1038/297197a0

Petrovic, N., Meng, B., Ravnikar, M., Mavric, I., Gonsalves, D., 2003a. First Detection of Rupestris stem pitting associated virus Particles by Antibody to a Recombinant Coat Protein. Plant Dis. 87, 510-514. doi:10.1094/PDIS.2003.87.5.510

Poojari, S., Alabi, O.J., Fofanov, V.Y., Naidu, R.A., 2013. A Leafhopper-Transmissible DNA Virus with Novel Evolutionary Lineage in the Family Geminiviridae Implicated in Grapevine Redleaf Disease by Next-Generation Sequencing. PLOS ONE 8, e64194. doi:10.1371/journal.pone.0064194

Prosser, S.W., Goszczynski, D.E., Meng, B., 2007. Molecular analysis of double-stranded RNAs reveals complex infection of grapevines with multiple viruses. Virus Res. 124, 151-159. doi:10.1016/j.virusres.2006.10.014

Prosser, S.W., Xiao, H., Li, C., Nelson, R.S., Meng, B., 2015. Subcellular localization and membrane association of the replicase protein of grapevine rupestris stem pitting-associated virus, family Betaflexiviridae. J. Gen. Virol. 96, 921-932. doi:10.1099/jgv.0.000019

Rambaut, A., Drummond, A., 2015. Figtree. Available at: http://tree.bio.ed.ac.uk/software/figtree/

Raski, D.J., Goheen, A.C., Lider, L.A., Meredith, C.P., 1983. Strategies Against Grapevine Fanleaf Virus and Its Nematode Vector. Plant Dis. 67, 335-338.

Rebelo, A.R., Niewiadomski, S., Prosser, S.W., Krell, P., Meng, B., 2008. Subcellular localization of the triple gene block proteins encoded by a Foveavirus infecting grapevines. Virus Res. 138, 57-69. doi:10.1016/j.virusres.2008.08.011

Reid, K.E., Olsson, N., Schlosser, J., Peng, F., Lund, S.T., 2006. An optimized grapevine RNA isolation procedure and statistical determination of reference genes for real-time RT-PCR during berry development. BMC Plant Biol. 6, 27. doi:10.1186/1471-2229-6-27 
Reisch, B., Pratt, C., 1996. Grapes, in: Janick, J., Moore, J. (Eds.), Fruit Breeding, Volume II: Vine and Small Fruits Crops. Wiley \& Sons, New York.

Renault-Spilmont, A.S., Grenan, S., Boursiquot, J.M., 2003. Syrah decline in French vineyards. Presented at the 14th ICVG Conference, Locorotondo, Italy, p. 144.

Roossinck, M.J., Martin, D.P., Roumagnac, P., 2015. Plant Virus Metagenomics: Advances in Virus Discovery. Phytopathology 105, 716-727. doi:10.1094/PHYTO-12-14-0356-RVW

Roratto, P.A., Buchmann, D., Santos, S., Bartholomei-Santos, M.L., 2008. PCR-mediated recombination in development of microsatellite markers: mechanism and implications. Genet. Mol. Biol. 31, 58-63. doi:10.1590/S1415-47572008000100012

Rowhani, A., Zhang, Y.P., Chin, H., Minafra, A., Golino, D.A., Uyemoto, J.K., 2000. Grapevine rupestris stem pitting associated virus: population diversity, titer in the host and possible transmission vector., in: International Council for the Study of Viruses and Virus Diseases of the Grapevine (Ed.), Extended Abstracts 13th Meeting of ICVG. University of Adelaide, Adelaide, Australia, p. 37.

Rozanov, M.N., Koonin, E.V., Gorbalenya, A.E., 1992. Conservation of the putative methyltransferase domain: a hallmark of the "Sindbis-like" supergroup of positive-strand RNA viruses. J. Gen. Virol. 73 ( Pt 8), 2129-2134. doi:10.1099/0022-1317-73-8-2129

Rubio, L., Ayllón, M.A., Kong, P., Fernández, A., Polek, M., Guerri, J., Moreno, P., Falk, B.W., 2001. Genetic variation of Citrus tristeza virus isolates from California and Spain: evidence for mixed infections and recombination. J. Virol. 75, 8054-8062.

Sabanadzovic, S., Abou-Ghanem, N., Castellano, M.A., Digiaro, M., Martelli, G.P., 2000. Grapevine fleck virus-like viruses in Vitis. Arch. Virol. 145, 553-565.

Sabanadzovic, S., Ghanem-Sabanadzovic, N.A., Saldarelli, P., Martelli, G.P., 2001. Complete nucleotide sequence and genome organization of Grapevine fleck virus. J. Gen. Virol. 82, 2009-2015. doi:10.1099/0022-1317-82-8-2009

Sambrook, J., Maniatis, T., Fritsch, E.F., Laboratory, C.S.H., 1987. Molecular cloning : a laboratory manual, 2nd ed. Cold Spring Harbor, N.Y. : Cold Spring Harbor Laboratory Press. 
Savino, V., Boscia, D., Martelli, G.P., 1989. Rugose wood complex of grapevine: can grafting to Vitis indicators discriminate between diseases?, in: Proceedings of the 9th Meeting of ICVG. Kiryat Anavim, Israel, pp. 91-94.

SAWIS, 2016. South African Wine Industry Statistics (Annual Publication No. 41). South African Wine Industry Statistics.

Simon-Loriere, E., Holmes, E.C., 2011. Why do RNA viruses recombine? Nat. Rev. Microbiol. 9, 617-626. doi:10.1038/nrmicro2614

Smyth, R.P., Schlub, T.E., Grimm, A., Venturi, V., Chopra, A., Mallal, S., Davenport, M.P., Mak, J., 2010. Reducing chimera formation during PCR amplification to ensure accurate genotyping. Gene 469, 45-51. doi:10.1016/j.gene.2010.08.009

Soultanas, P., Wigley, D.B., 2001. Unwinding the "Gordian knot" of helicase action. Trends Biochem. Sci. 26, 47-54.

Stamatakis, A., 2014. RAxML version 8: a tool for phylogenetic analysis and post-analysis of large phylogenies. Bioinformatics 30, 1312-1313. doi:10.1093/bioinformatics/btu033

Stamp, J.A., 2004. Syrah Decline. Wine Bus. Mon. 28-37.

Steenwerth, K., Smith, R.J., Battany, J., Ujemoto, J., 2007. Is Syrah grapevine sensitive to herbicides, in: Proceedings of the Syrah Vine Health Symposium. University of California, pp. 19-20.

Stewart, S., Nassuth, A., 2001. RT-PCR Based Detection of Rupestris stem pitting associated virus Within Field-Grown Grapevines Throughout the Year. Plant Dis. 85, 617-620. doi:10.1094/PDIS.2001.85.6.617

Strauss, J.H., Strauss, E.G., 1994. The alphaviruses: gene expression, replication, and evolution. Microbiol. Rev. 58, 491-562. 
Teliz, D., Valle, P., Goheen, A.C., Luevano, S., 1980. Grape corky bark and Stem pitting in Mexico. I. Occurrence, natural spread, distribution, effect on yield and evaluation of symptoms in 128 grape cultivars., in: Extended Abstracts 7th Meeting of ICVG. Niagra Falls, New York, USA, pp. 51-64.

Terlizzi, F., Li, C., Ratti, C., Qiu, W., Credi, R., Meng, B., 2011. Detection of multiple sequence variants of Grapevine rupestris stem pitting-associated virus using primers targeting the polymerase domain and partial genome sequencing of a novel variant. Ann. Appl. Biol. 159, 478-490. doi:10.1111/j.1744-7348.2011.00512.x

Terlizzi, F., Ratti, C., Filippini, G., Pisi, A., Credi, R., 2010. Detection and molecular characterization of Italian Grapevine rupestris stem pitting-associated virus isolates. Plant Pathol. 59, 48-58. doi:10.1111/j.1365-3059.2009.02156.x

Terral, J.-F., Tabard, E., Bouby, L., Ivorra, S., Pastor, T., Figueiral, I., Picq, S., Chevance, J.-B., Jung, C., Fabre, L., Tardy, C., Compan, M., Bacilieri, R., Lacombe, T., This, P., 2010. Evolution and history of grapevine (Vitis vinifera) under domestication: new morphometric perspectives to understand seed domestication syndrome and reveal origins of ancient European cultivars. Ann. Bot. 105, 443-455. doi:10.1093/aob/mcp298

This, P., Lacombe, T., Thomas, M.R., 2006. Historical origins and genetic diversity of wine grapes. Trends Genet. TIG 22, 511-519. doi:10.1016/j.tig.2006.07.008

Tsai, C.W., Daugherty, M.P., Almeida, R.P.P., 2012. Seasonal dynamics and virus translocation of Grapevine leafroll-associated virus 3 in grapevine cultivars. Plant Pathol. 61, 977-985. doi:10.1111/j.1365-3059.2011.02571.x

Tsai, C.-W., Rowhani, A., Golino, D.A., Daane, K.M., Almeida, R.P.P., 2010. Mealybug transmission of Grapevine leafroll viruses: an analysis of virus-vector specificity. Phytopathology 100, 830-834. doi:10.1094/PHYTO-100-8-0830

Udaskin, M.L., 2016. Investigation into the proteolytic processing and localization of the replicase polyprotein of Grapevine rupestris stem pitting-associated virus. (M.Sc. Thesis). University of Guelph, Guelph, Ontario, Canada. 
Verchot-Lubicz, J., 2005. A new cell-to-cell transport model for Potexviruses. Mol. Plant-Microbe Interact. MPMI 18, 283-290. doi:10.1094/MPMI-18-0283

Villate, L., Fievet, V., Hanse, B., Delemarre, F., Plantard, O., Esmenjaud, D., van Helden, M., 2008. Spatial distribution of the dagger nematode Xiphinema index and its associated Grapevine fanleaf virus in French vineyard. Phytopathology 98, 942-948. doi:10.1094/PHYTO-98-80942

Waigmann, E., Curin, M., Heinlein, M., 2007. Tobacco Mosaic Virus - a Model for Macromolecular Cell-to-Cell Spread, in: Viral Transport in Plants, Plant Cell Monographs. Springer, Berlin, Heidelberg, pp. 29-62.

Wang, Q., Mawassi, M., Li, P., Gafny, R., Sela, I., Tanne, E., 2003. Elimination of grapevine virus A (GVA) by cryopreservation of in vitro-grown shoot tips of Vitis vinifera L. Plant Sci. 165, 321-327. doi:10.1016/S0168-9452(03)00091-8

White, E.J., Venter, M., Hiten, N.F., Burger, J.T., 2008. Modified cetyltrimethylammonium bromide method improves robustness and versatility: the benchmark for plant RNA extraction. Biotechnol. J. 3, 1424-1428. doi:10.1002/biot.200800207

Wierzchoslawski, R., Dzianott, A., Bujarski, J., 2004. Dissecting the requirement for subgenomic promoter sequences by RNA recombination of brome mosaic virus in vivo: evidence for functional separation of transcription and recombination. J. Virol. 78, 8552-8564. doi:10.1128/JVI.78.16.8552-8564.2004

Xiao, H., Kim, W.-S., Meng, B., 2015. A highly effective and versatile technology for the isolation of RNAs from grapevines and other woody perennials for use in virus diagnostics. Virol. J. 12, 171. doi:10.1186/s12985-015-0376-3

Zhang, Y.P., Uyemoto, J.K., Golino, D.A., Rowhani, A., 1998. Nucleotide sequence and rt-PCR detection of a virus associated with grapevine rupestris stem-pitting disease. Phytopathology 88, 1231-1237. doi:10.1094/PHYTO.1998.88.11.1231 